\title{
هدى تقبل أعضاء هيئة التدريس بجاهعة الطائف لمعايير تطوير المناهج الدراسية في ضوء الجودة الشاملة
}

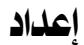 \\ د ـ مبالغفار بر. عبدالعزيز قرشحس \\ استاذ مسـاعد بقسم العلوم التربوية \\ كلية التربية - جامعة الطائف
}

مجلة بحوث التربية النوعية - جامعة المنصورة

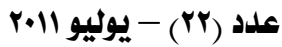




\title{
هدى تقبل أعضاء هيئة التدريس بجاهعة الطائف لمعايير تطوير المناهج الدراسية في ضوء الجودة الشاهلة
}

\author{
إعداد

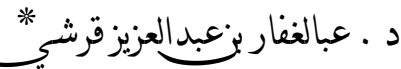

هقدمة:

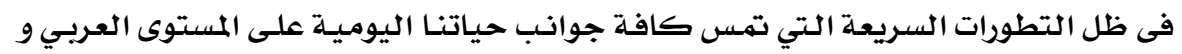

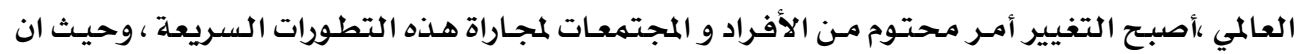

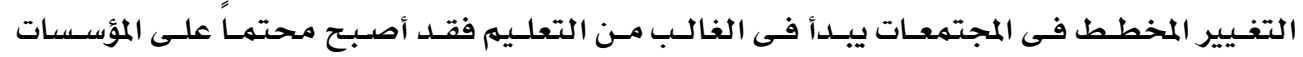

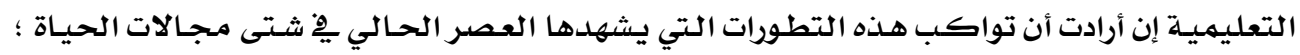

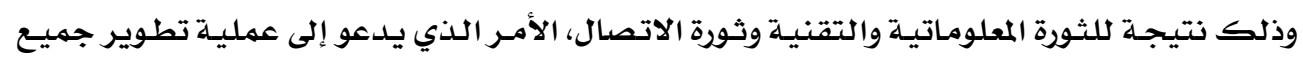

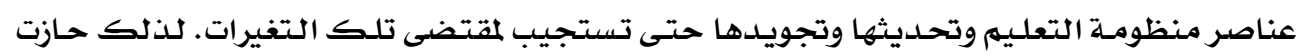

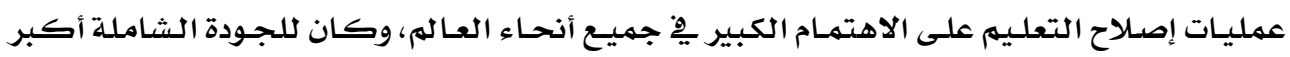

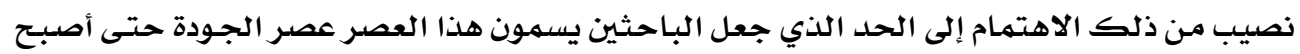

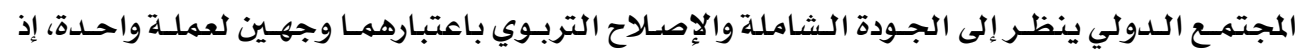

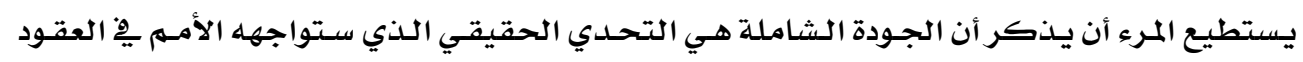

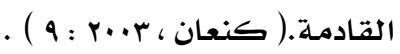

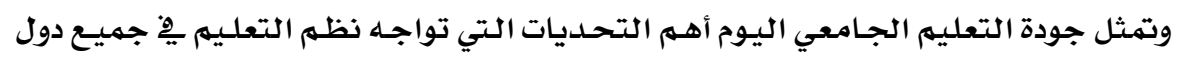

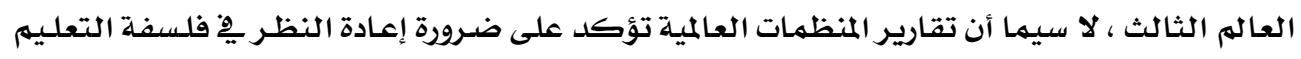

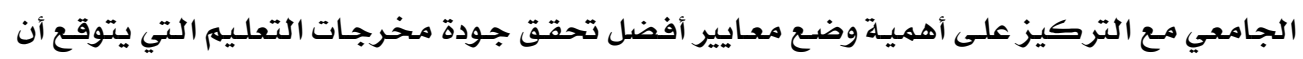

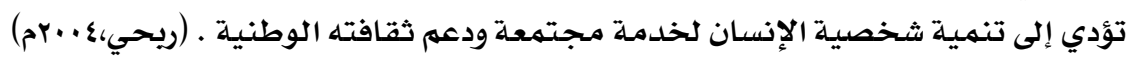

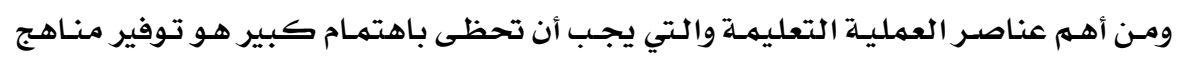

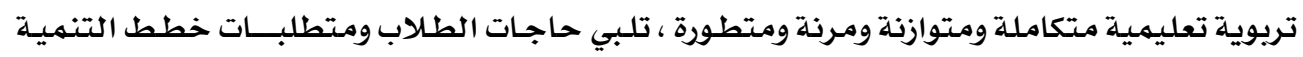

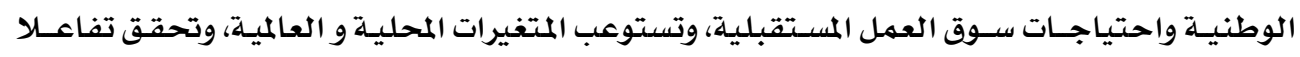

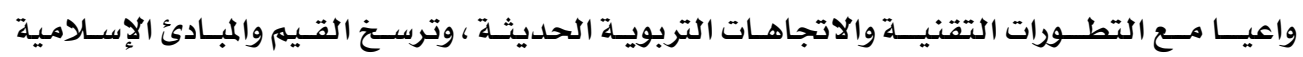

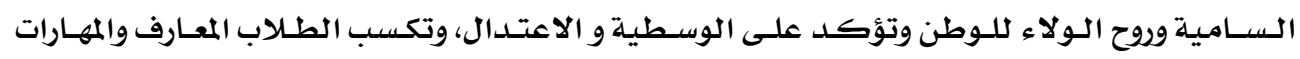

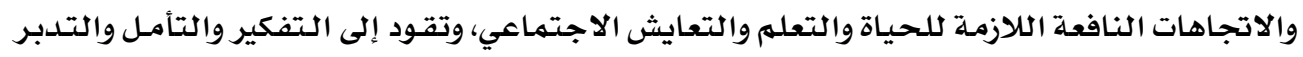

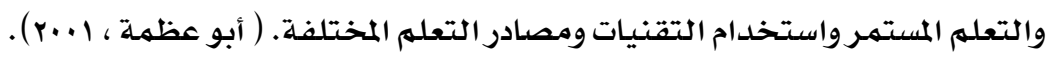

* أستاذ مساعد بقسم العلوم التربوية - كلية التربية - جامعة الطائف 


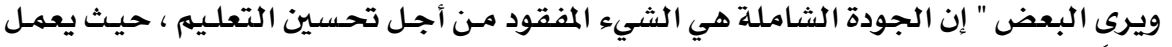

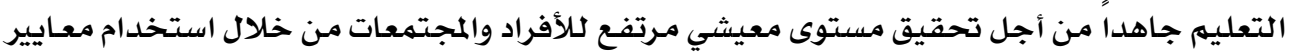

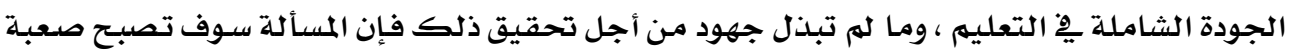

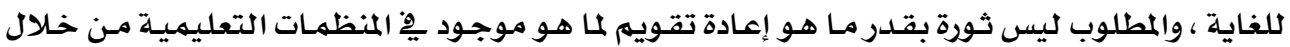

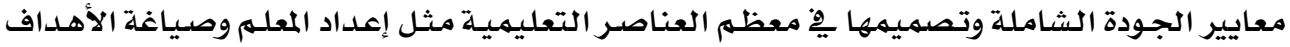

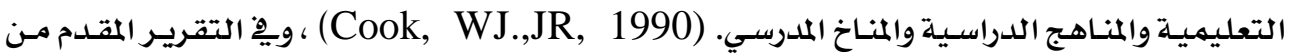

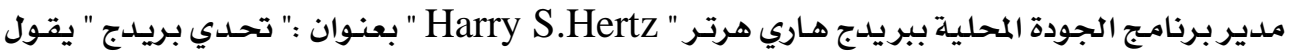

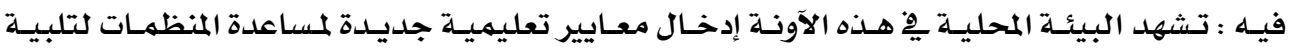

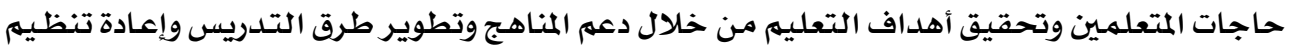

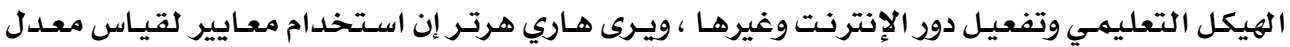

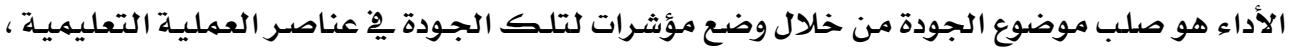

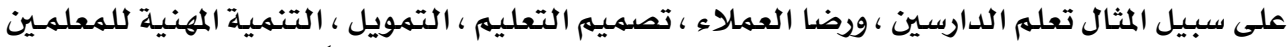

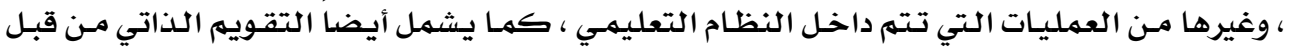

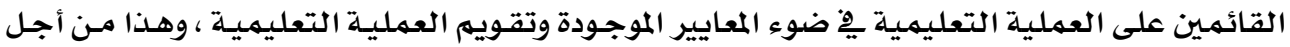

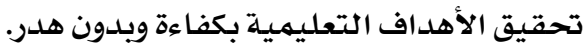
ونظـرا لأهميـة دور كليـة التربيـة المتفـرد يِّ تزويـد المؤسسـات التعليميـة بـالمعلمـين والمعلمـات

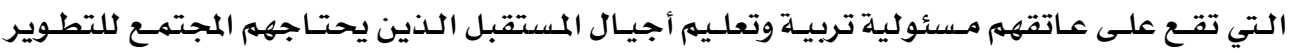

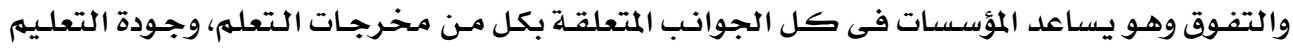

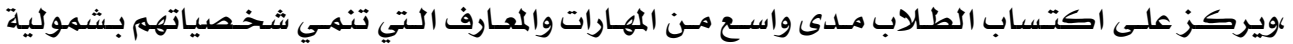

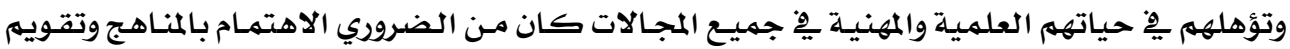

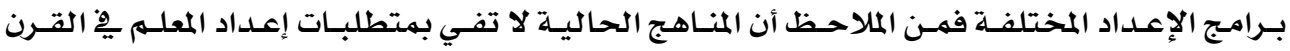

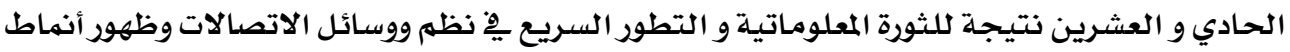

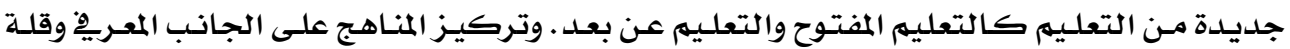

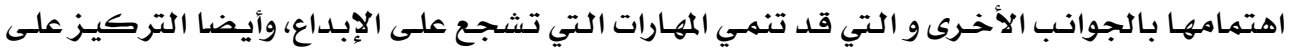

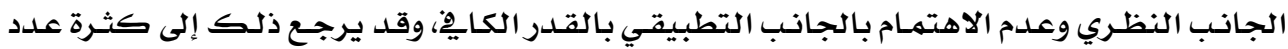

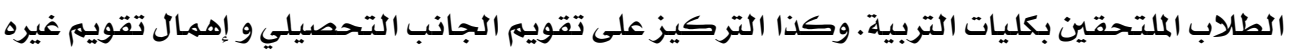

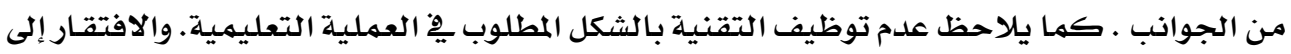

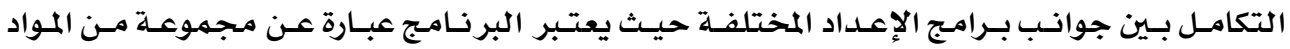

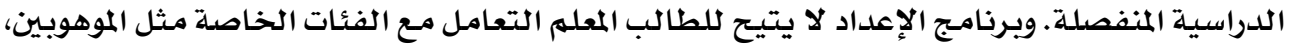

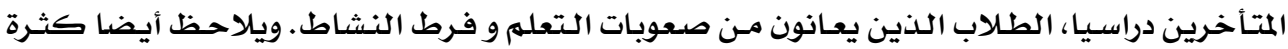

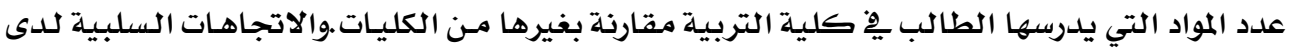

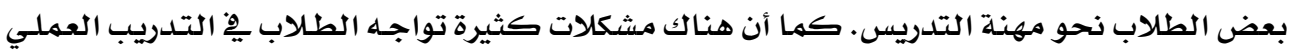

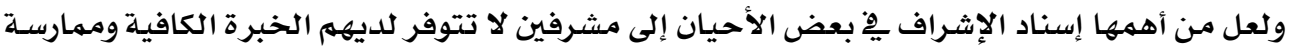


الإثراف بالطرق التقليدية. وبطء عمليات التطوير و الإصلاح ِِّ كليات التربية كما أن التطوير لا

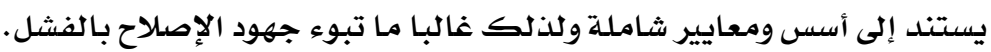
ولذلك فهناك عدد كبير من الدراسات التي هدفت إلى تطبيق الجودة الشاملة يفِ التعليهم

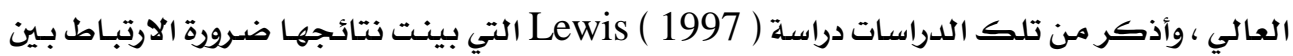

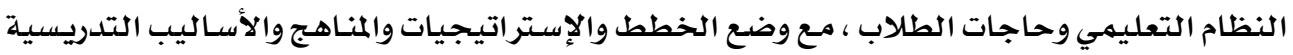

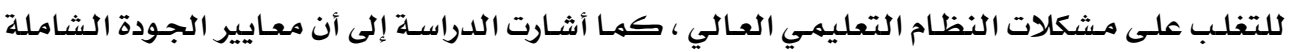

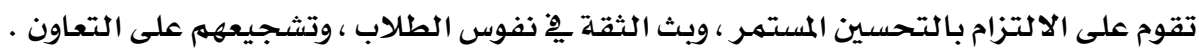

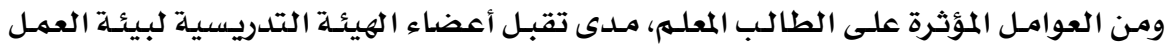

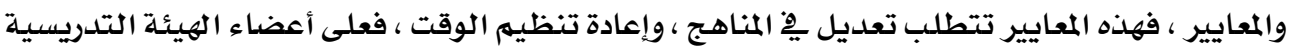

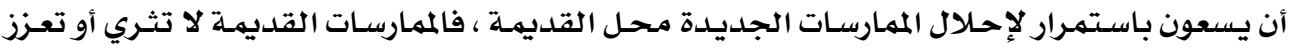

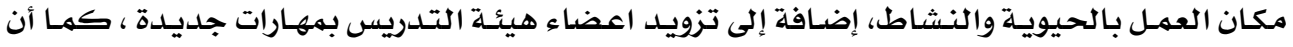

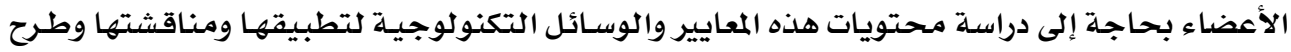

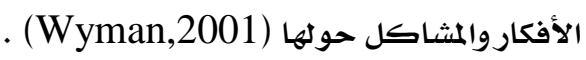

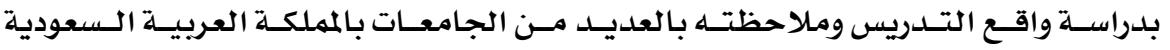

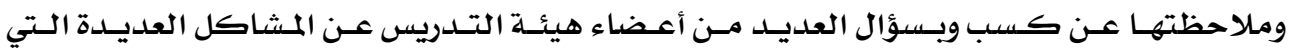

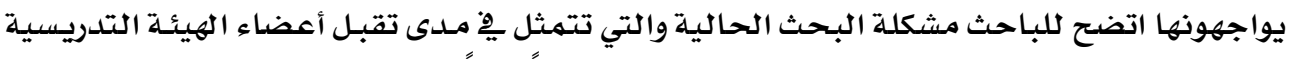

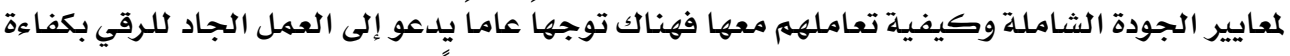

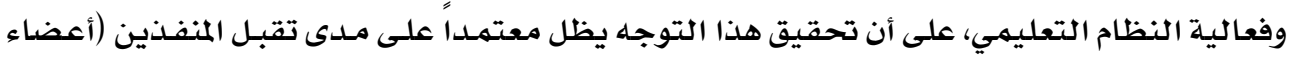

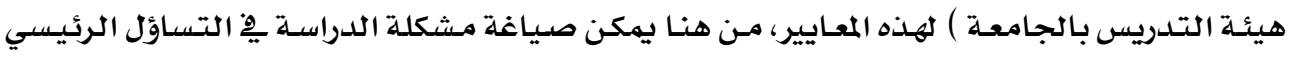
التالي : (1)

ما مدى تقبل أعضاء هيئة التدريس بجامعة الطائف لمعايير تطوير المناهج الدراسية فِ ضوء

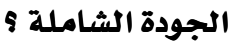

\section{ويتفرع من هذا التساؤل الأسئلة الفرعية التالية:-}

ا. ما مدى تقبل أعضاء هيئـة التـدريس بجامعـة الطائف لمعايير تطوير المنـاهج الدراسية ِِِ ضوء

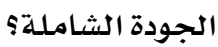

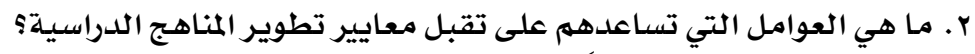

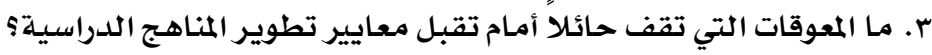

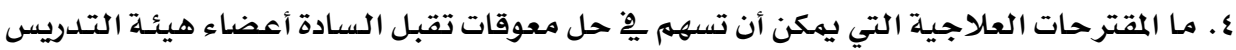
لمعايير تطوير المناهج؟ 


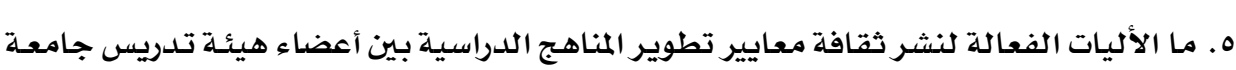

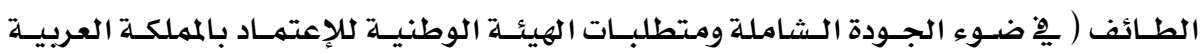
السعودية) أهميسية الدراسة :

تستمدل هذه الدراسـة أهميتها من الآتي :

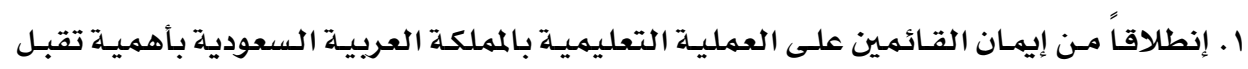

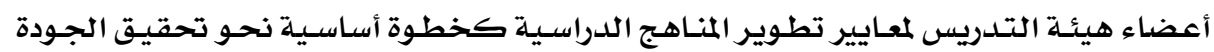

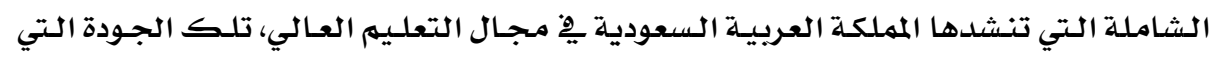

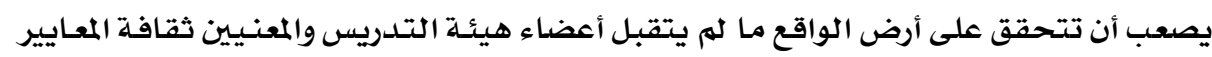

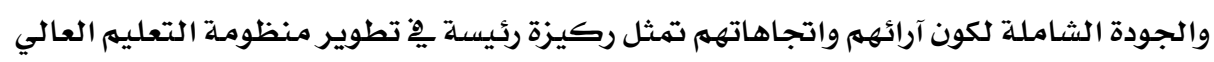
بالمملكة العربية السعودية.

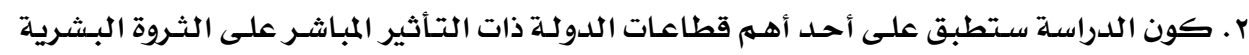

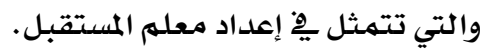

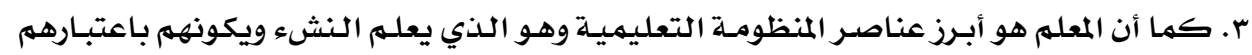

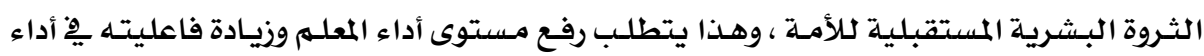

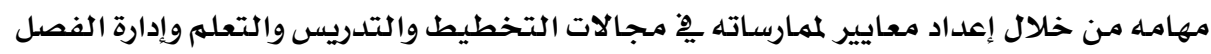
والتقويم وغيرها ، والجودة الشاملة تجسد الأسلوب الأمثل لدفع عمليكادية التحطية التربية والتعليه. أهداف البمث: واثن

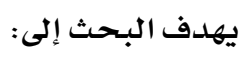

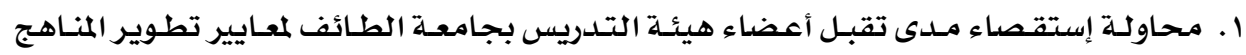
الدراسية يِّ ضوء الجودة الشعاملة.

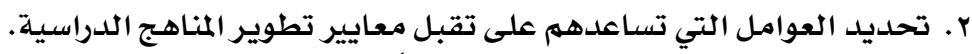

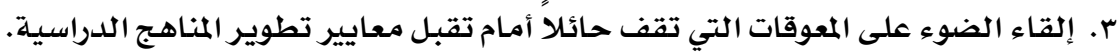

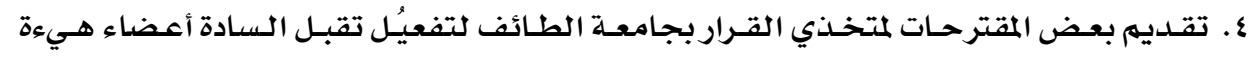
التدريس لمعايير تطوير المناهج.

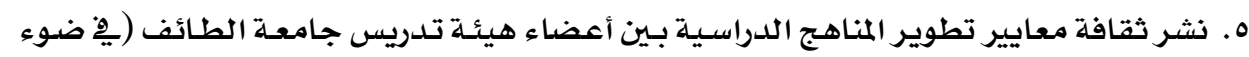

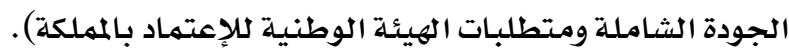

\section{حدود الدراسة :}

أ- حدود بشرية :

طبقت الدراسـة على عينـة ممثلـة مـن السـادة أعضاء هيئسة التـدريس (120 ) ) مـن مختلف 
جامعة الطائف بالمملكة العربية السعودية.

ج- حدود موضوعية: تقتصر الدراسـة الحالية على معايير المناهـج الدراسية بجـامعة الطائف.

د - حدود زمنية:

طبقت الدراسـة يخ الفصل الدراسي الأول للعام اسعا - بrعاهـ .

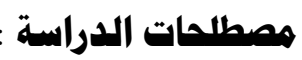

• تصريف المنهج:

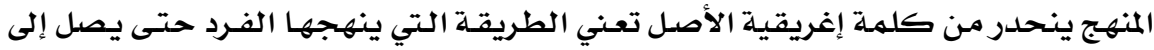

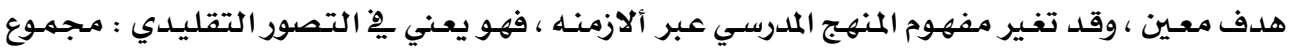

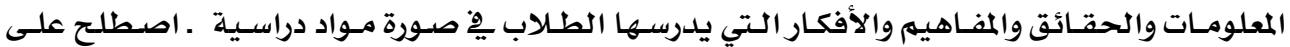
تسميتها بالمفردات الدراسيـة ـ ، ولكن المفهوم الحديث للمنهج يختلف عن التقليدي ، وذلك لان المنهج

$$
\text { المدرسي تطور نتيجـة عدة أسباب منها : }
$$

$$
\text { ا ـ التغيير الثقايِ الناشئ عن التطور العلهي والتقني. }
$$

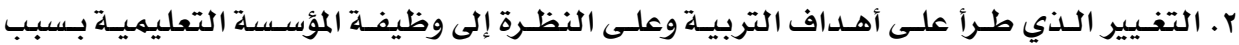
التغييرات التي طرأت على احتياجات المجتمع عِ العصدر الحديث. r. نتـائج البـحـوث العلميـة التي تنـاولت الجوانب المتعـددة للهـهـج التقليـدي والـتي أظهرت قصوراً

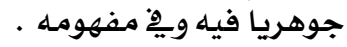

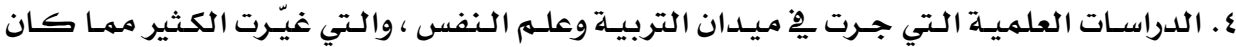

$$
\text { سائداً عن طبيعة المتعلهم وسيكولوجيتهه . }
$$

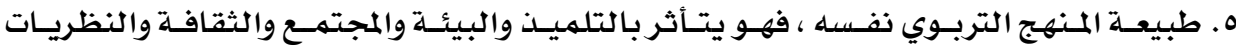

$$
\text { التربوية. }
$$

7. أعتقاد المعلمون بأن عملهم يقتصر على توصيل المعلومات التي تشتهمل المقـررات الدراسـية ،وقدل ترتب على ذلك آثارا سـيئـة لعـل مـن أبرزهـا مـا يلـي " : اعتمـاد طريقـة التـدريس على الآليـة التلقينيـة - فصل المقـررات الدراسـية وعـلـم ترابطهـا مـع بعـضها - إهمـال التوجـه التربـوي

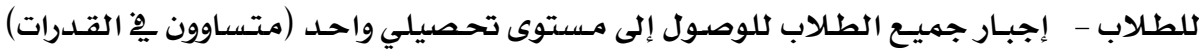
- عدم تشجيع الطلاب على البحث والإطلاع والمبادرة وتقديم الاقتراحسات ".

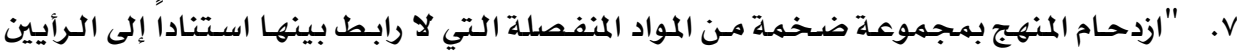

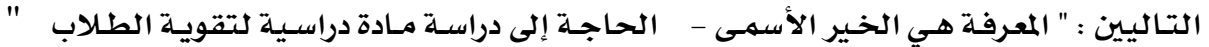

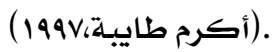




\section{ومن تعريفات المنهج:}

ا. إن المنهج هو جميع الخبر ات التربوية التي تقدمها المؤسسة التعليمية إلى الطلاب داخل الفصل

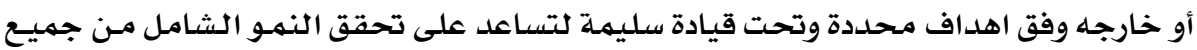

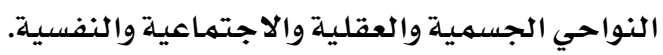

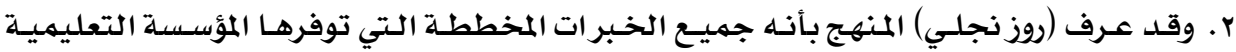

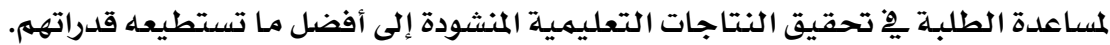

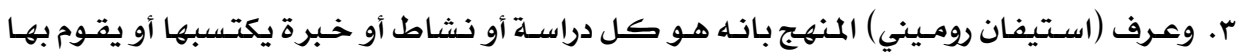

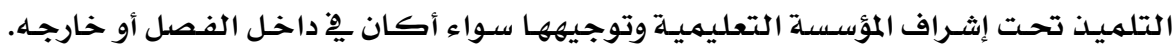

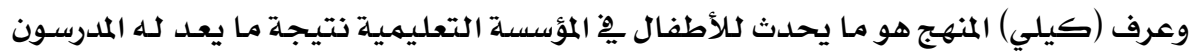

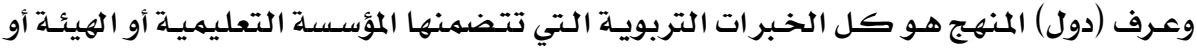
المؤسسة تحت إشراف ورقابة وتوجيه معين.

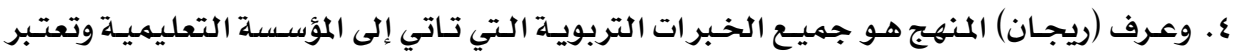

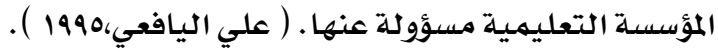

:Standards •

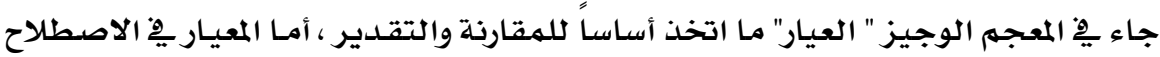

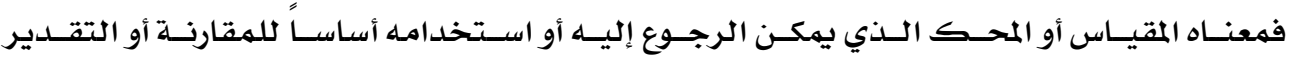

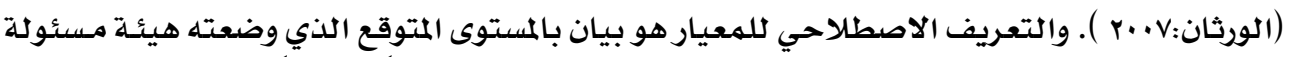

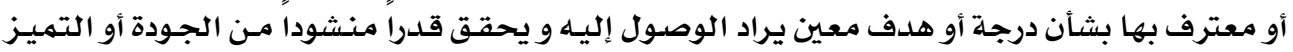
(National Quality Assurance:2004)

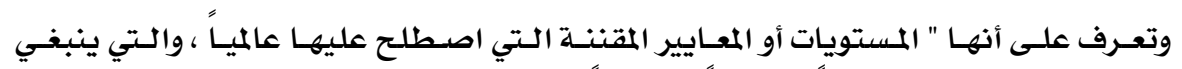

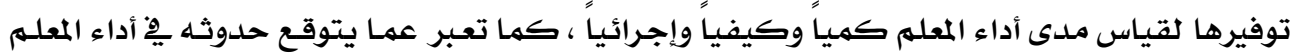

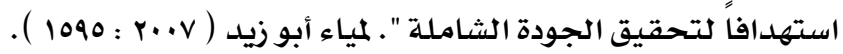

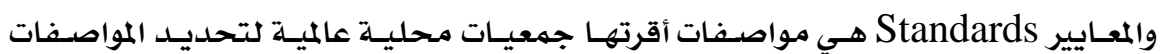

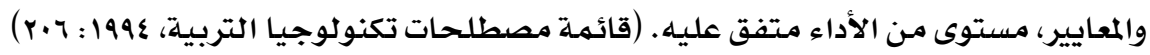
وتعرف نادية حسن علي (Y.... م) معايير الجودة الشاملة يْ التعليهم : بأنها تلك المواصفات

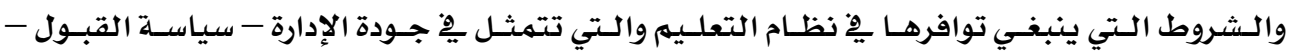

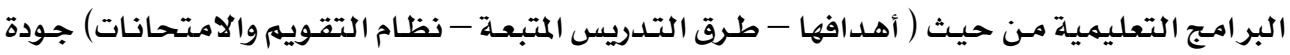

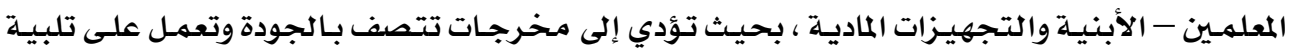
احتياجات المستفيدين. 


\section{وتعرف معايير المناهج الدراسية :}

بأنها الأهداف المطلوب تحقيقها من المتعلم، فهي تتفق والتوقعات العالميلة لما يجب أن يتعلمها

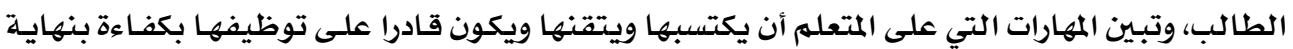

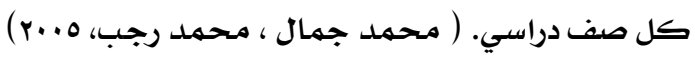

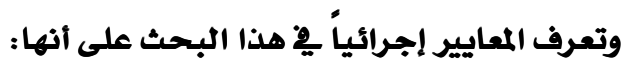

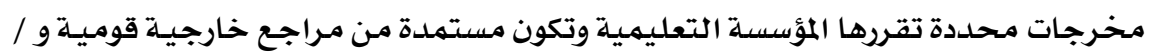

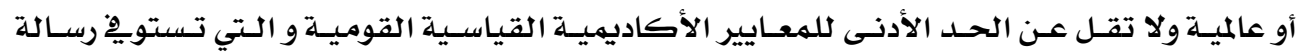

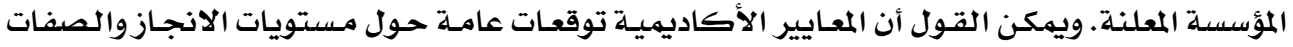

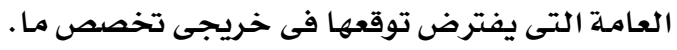

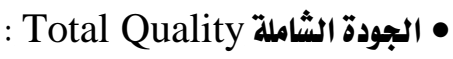

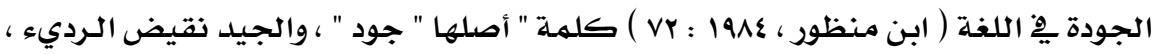

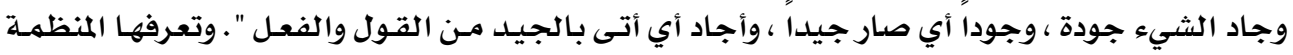

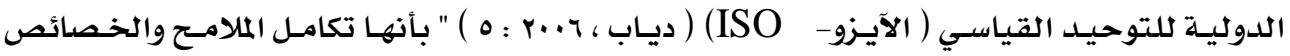
لمنتج أو خدمة ما بصورة تمكن من تلبية احتياجات ومتطلبـات محلدودة ".

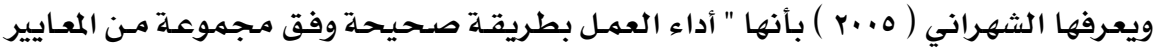

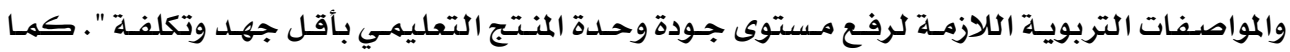

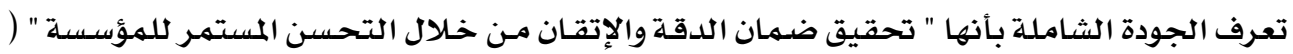

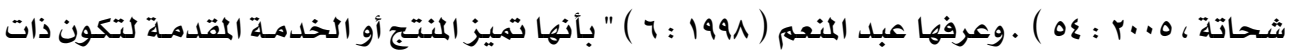

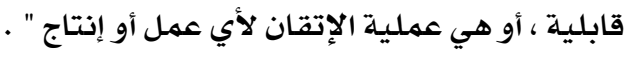
ويعرفها بروكا وبروكا (س99ام) بأنها " مجموعة مـن المبادئ والأسـاليب والوسيائل الفنيـة

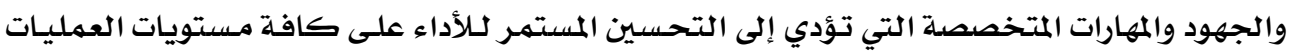

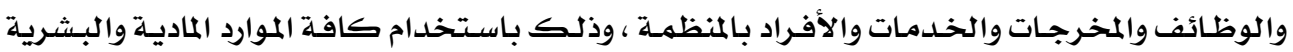

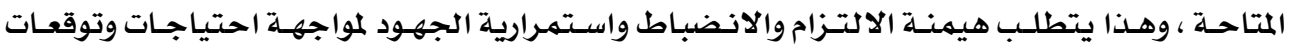

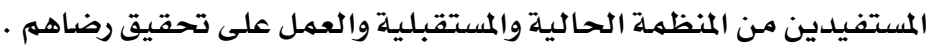

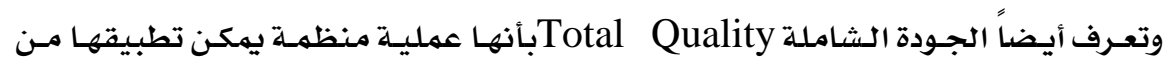

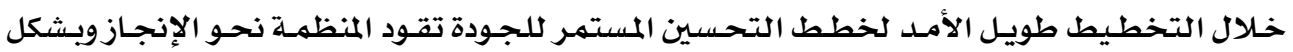

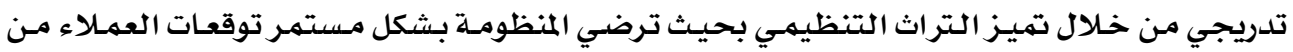

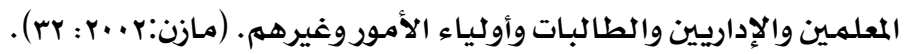

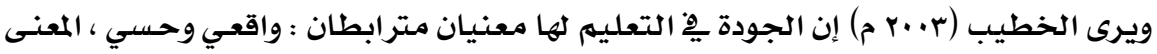

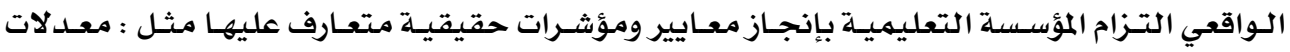




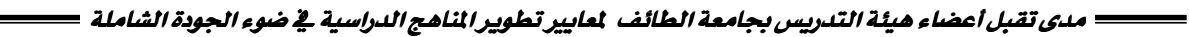

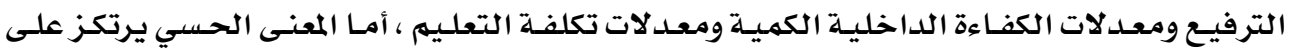

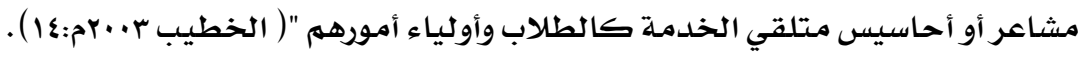

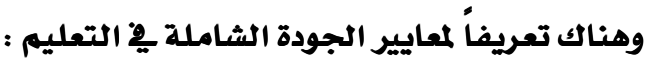

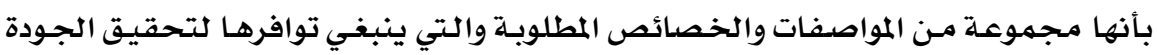

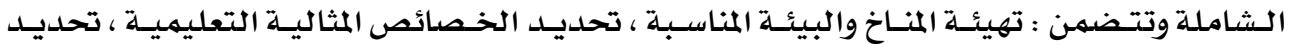

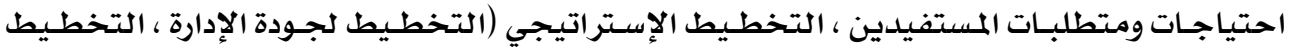

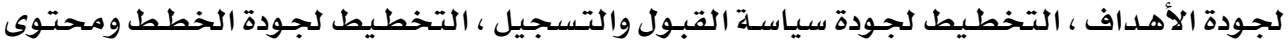

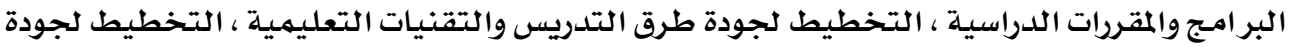

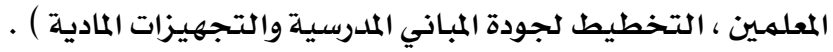

\section{ويمكن تعريف معايير الجودة والاعتماد الأكاديمي لكليات التربية إجرائيا بأنها:}

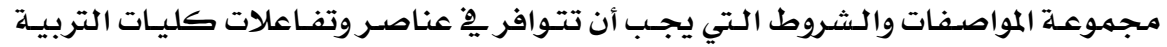

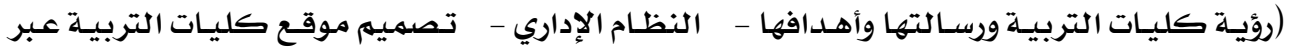

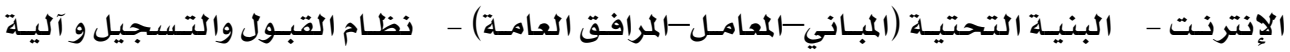

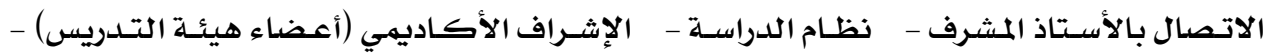

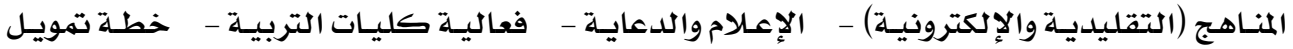

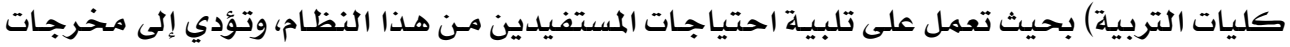

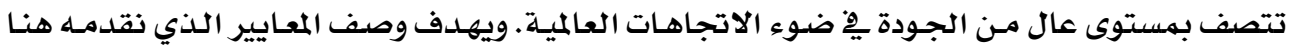

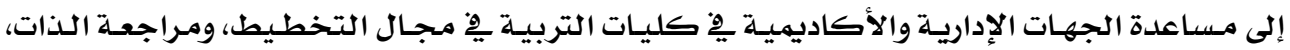

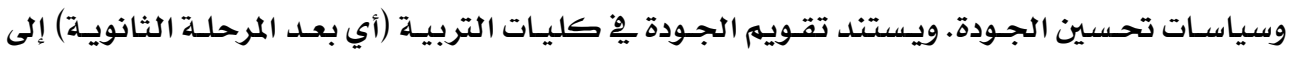

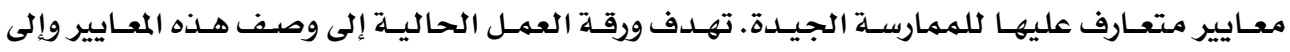
المساعدة يِّ تقويم الأداء استنادًا إليها.

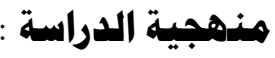

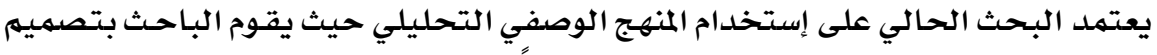

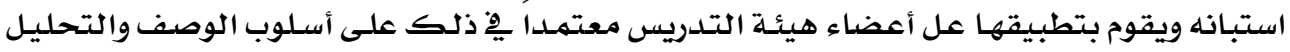
لمخرجات الاستبانة.

\section{إجراءات الدراسة :}

قام الباحثث بزيـارات ميدانيـة لجميـع كليـات جامعـة الطـائف للتحسدث مـع السـادة أعضـاء

$$
\text { هيئة التدريس بهدف التعرف على:- }
$$

1- مدى إلمامهم بثقافة معايير تطوير المناهج والخطط الدراسية

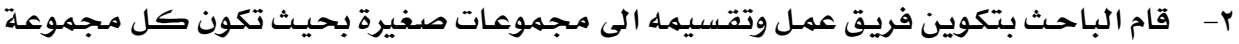

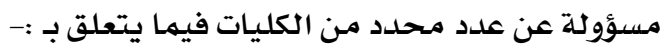


أ) تقديم الدعم الفني لأعضاء هيئة التدريس بالكليات المعنية فيما يتعلق بنشر ثقافة تطوير

المناهج والخطط الدراسية.

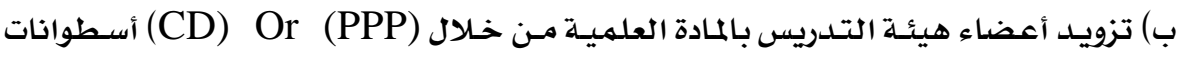

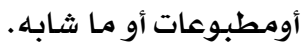

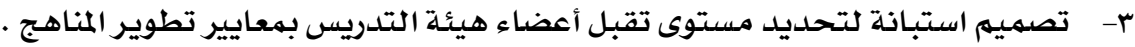

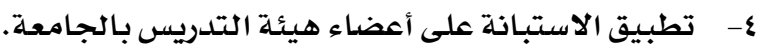

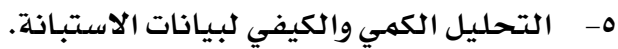

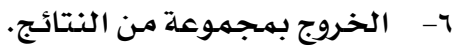

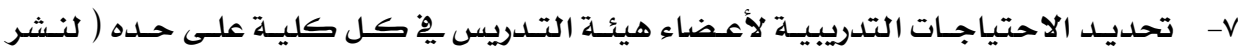

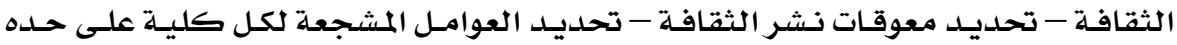

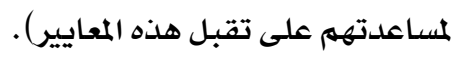

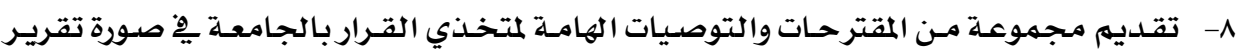

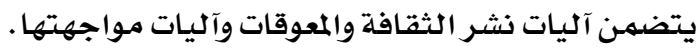

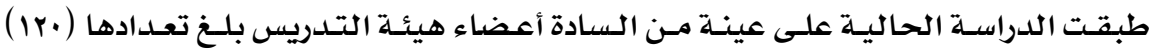

عضو بجامعة الطائف بالمملكة العربية السعودية.

\section{الإطار النظري والدراسات السابقة :}

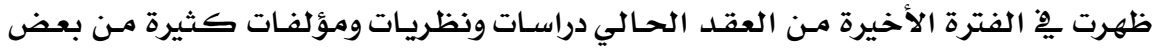

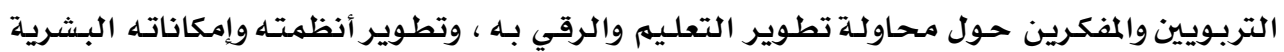

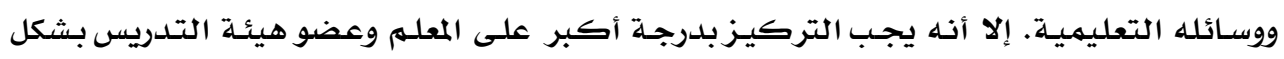

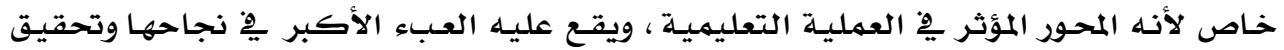

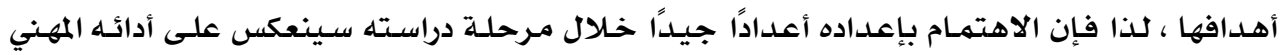

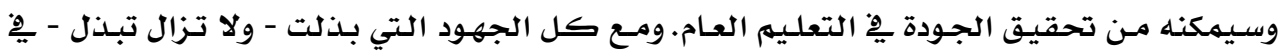

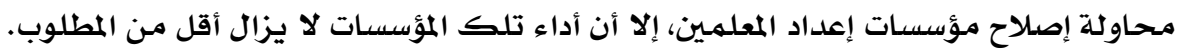

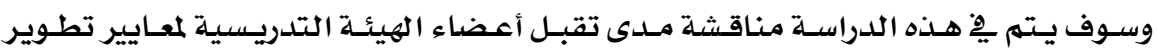

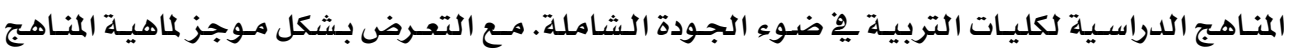

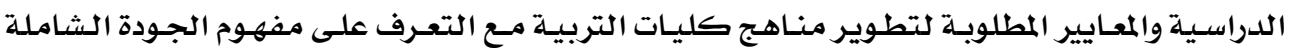

ومحتواها بشكل موجز.

أولاً: المنهج الدراسي

يرى هنسـون: إن مصطلح منهج أتى أصـلا مـن كلمهـة لاتينيـة تعني ميدان أو حلبـة السباق،

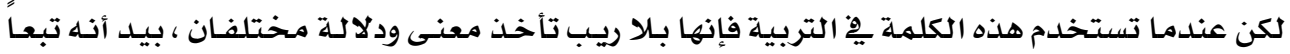

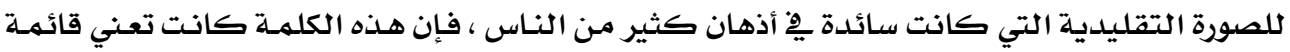




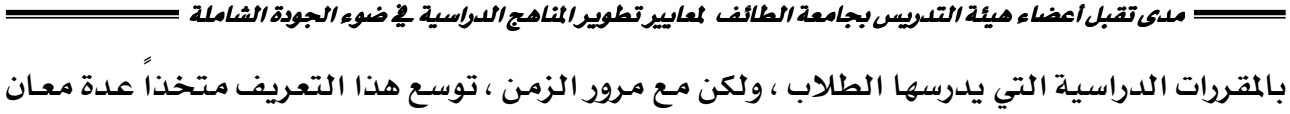

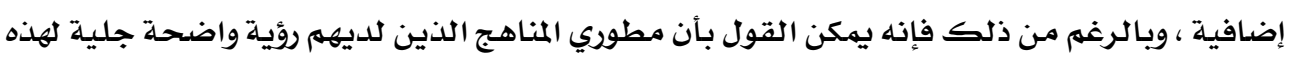

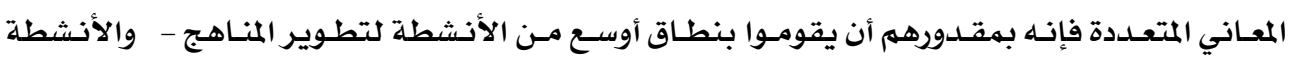

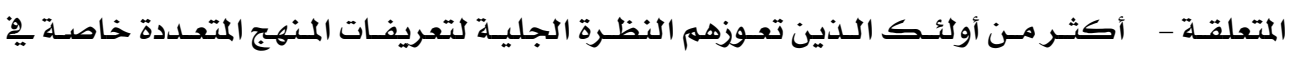

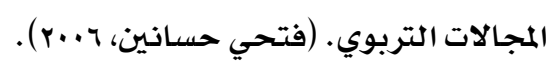

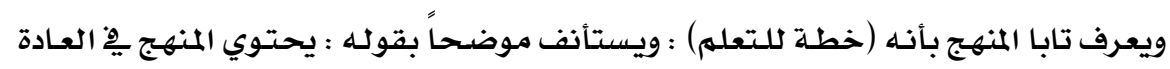

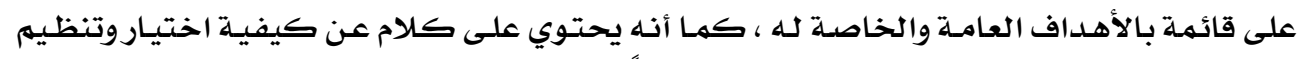

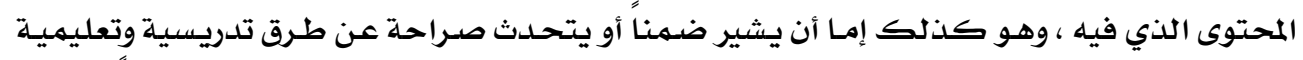

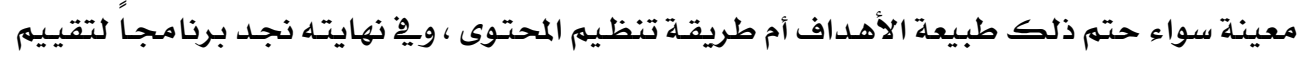

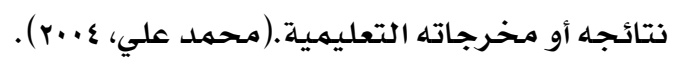

والمنهج بهفهومـه التقليدي يتمثل يِّ مجموعة المعلومات التي تعمل المؤسسـة على إكسابها

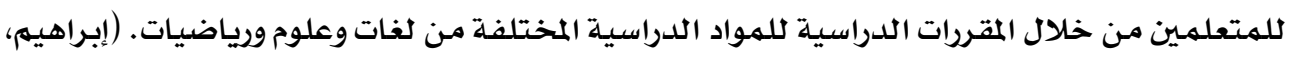

. (1999

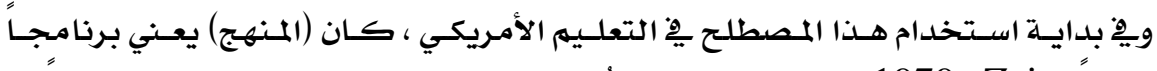

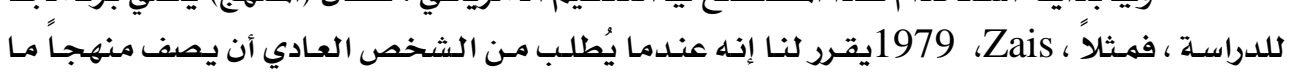

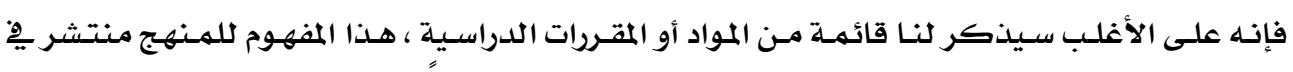

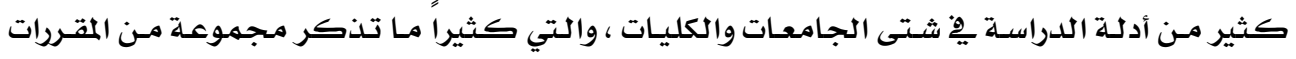

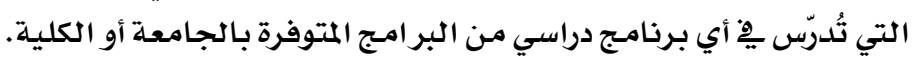

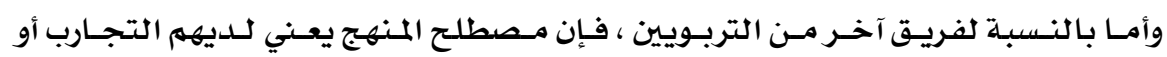

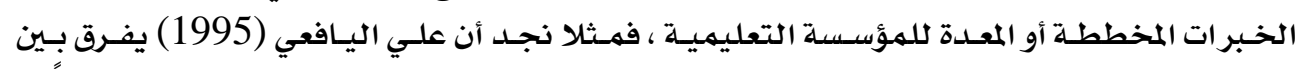

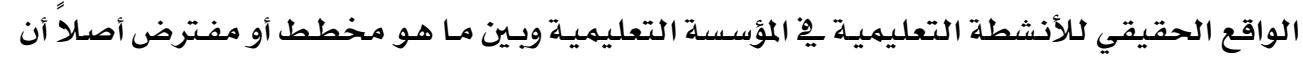
تقوم بـه من أنثطة.

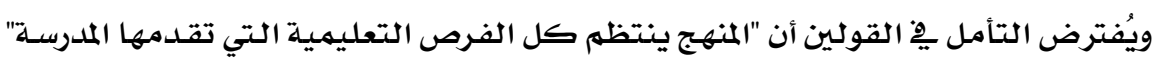

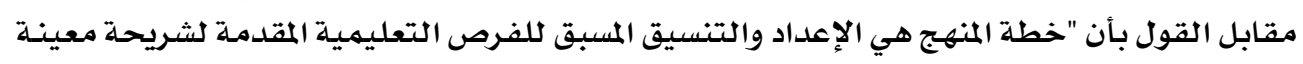

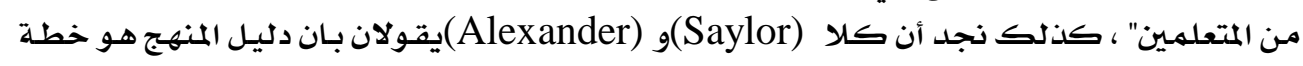

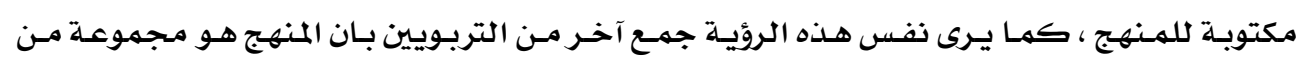
الخبرات.

يرى (Caswell \& Campell) أن المنهج هو كل الخبر ات التي يحصل عليها الطلاب مـع

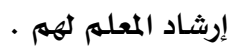

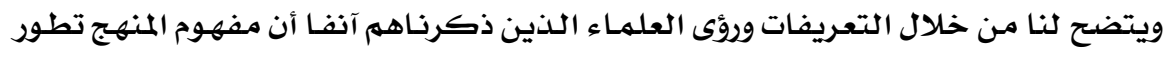

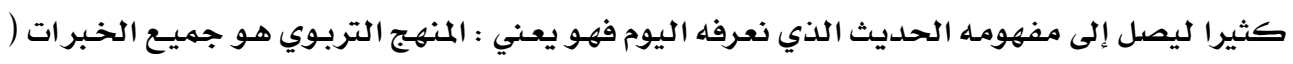

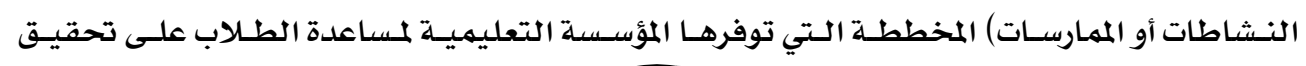


النتاجـات (العوائـد (التعلميـة المنشودة إلى أفضل مـا تستطيعه قدراتهم .. هو كل دراسـة أو نشاط أو

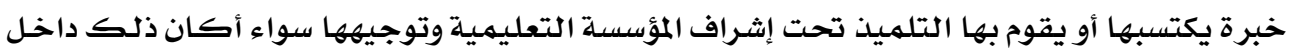

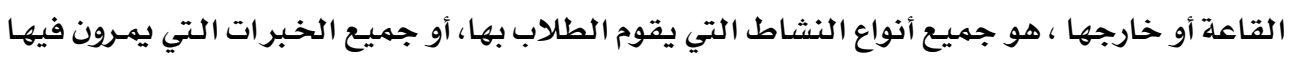

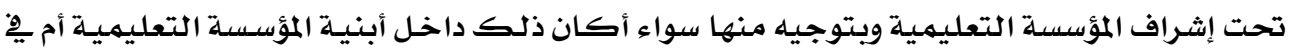

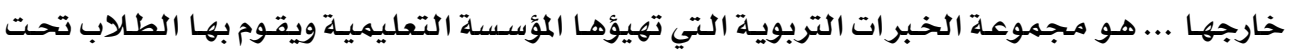

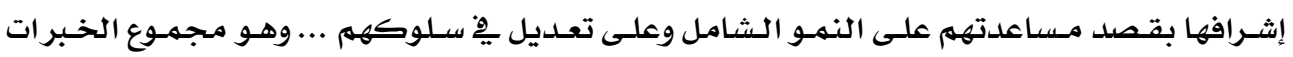

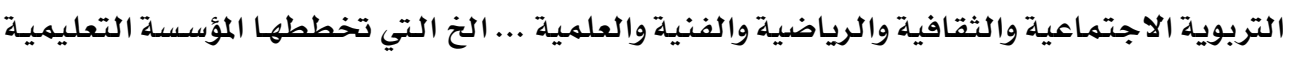

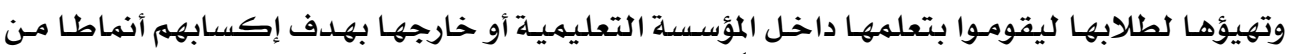

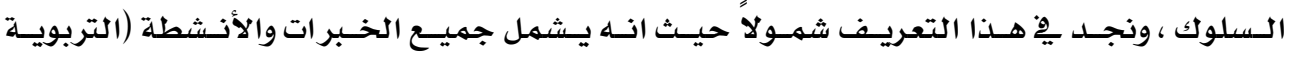

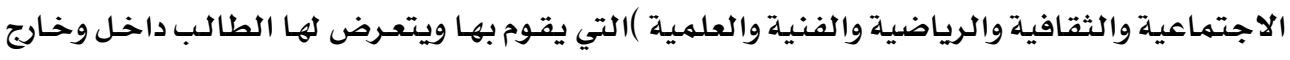

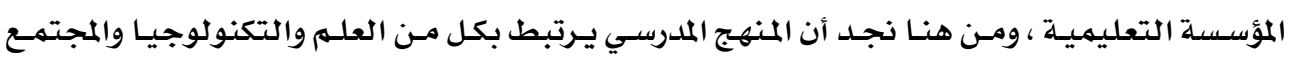

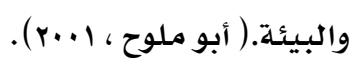

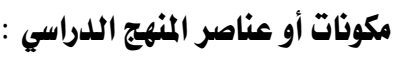

ا- الأهداف (( الهدف التعليمي )): هو شيء نسعى لتحقيقـه أو الوصـول إليهه ، والهـدف التعليمسي

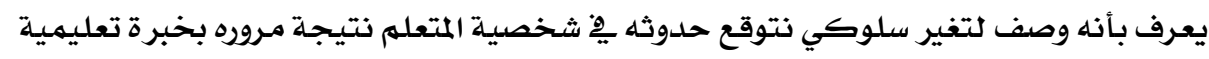

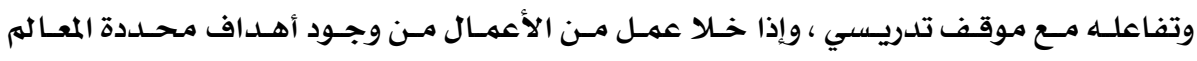

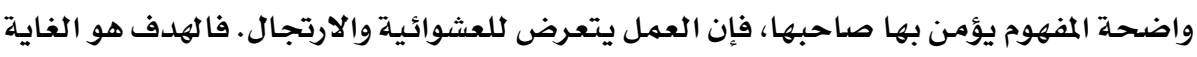

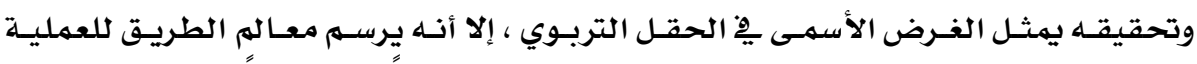

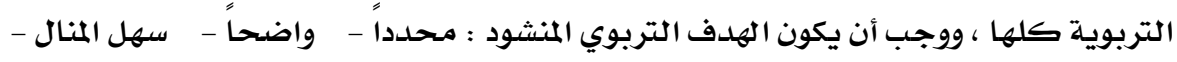

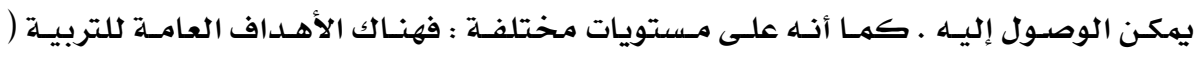

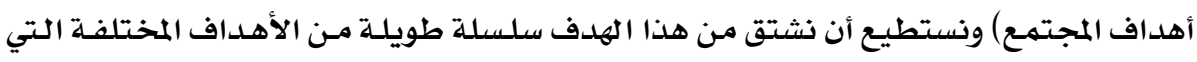

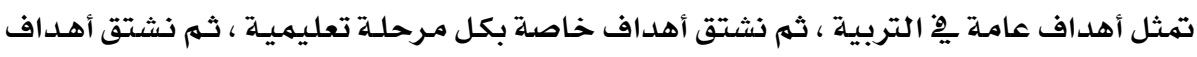

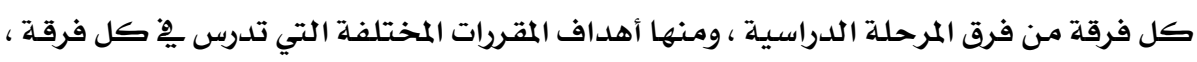

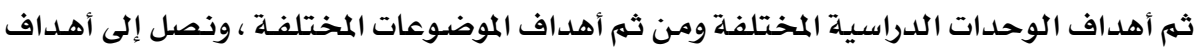

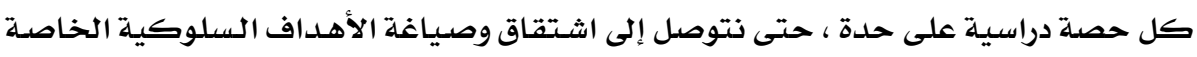

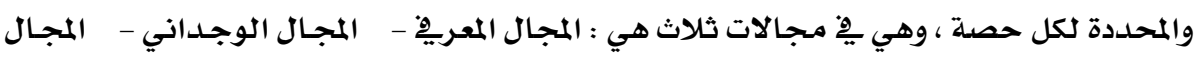

$$
\text { النفس حركي. }
$$

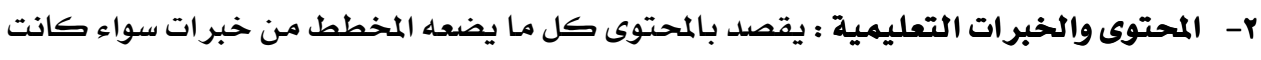

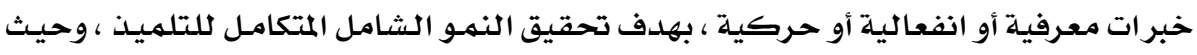

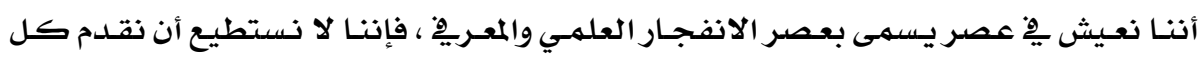

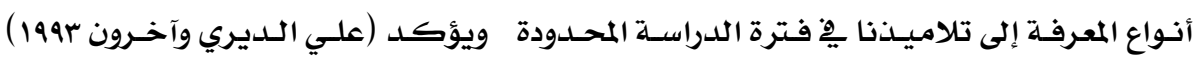

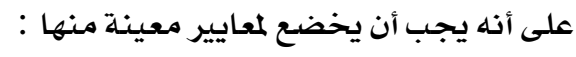




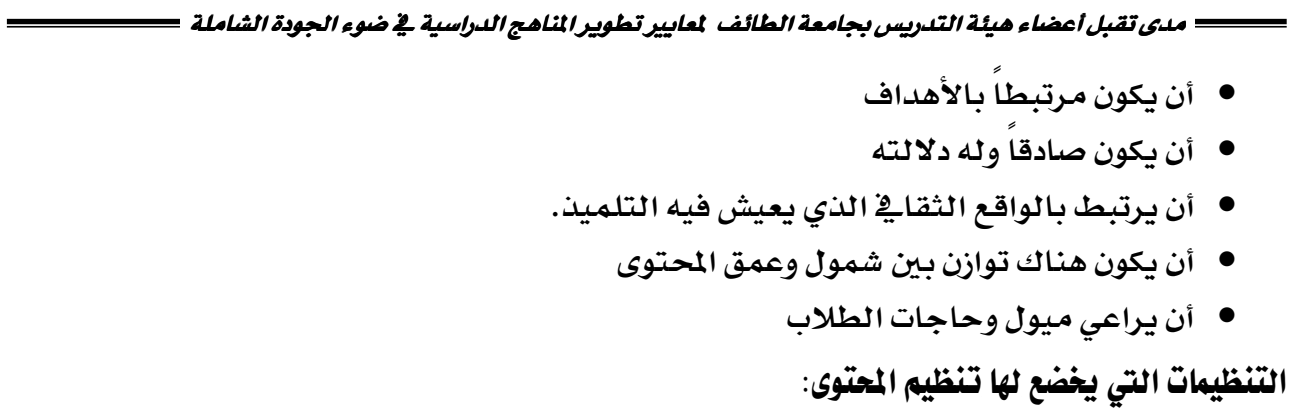

التنظيم المنطقي : وهو تنظيهم يسير وفق طبيعـة المادة مـن حيـث ترتب أجـزاء المحتـوى مـن

المعلوم إلى المجهول ، من البسيط إلى المركب ، مـن المحسوس إلى المجرد ، من المباشـر إلى غير المباشـر

التتظيم السيكولوجي : وهـو تنظيهم يسير وفق طبيعسة المتعلم ، حيـث ينظم المحتـوى وفقاً

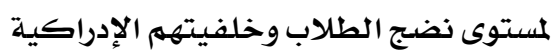

ب- طرق التعليم والتعلم : تركز على توصسيل المعلومـات إلى ذهـن التلميـذ بطريقـة تسهل

استيعابها ، فاستحدثت طرق جديدة كالطريقة الاستتباطية - وطريقة حل المشكلات - وطريقة التعلـيهم المبر مـج وغيرهـا مـن الطـرق .وقد كانـت مـن قبـل تهـتم بـتزويـد الطـلاب بالمعلومـات فأصسبحت تهدف إلى تحقيق النمـو الشامل المتكامـل للتلميـذ يِ جميـع المجـالات ، وهـذا الهدف سـاعد على تغيير طرق التدريس لتحقيق الهدف الشامل.

: -الوسائل التعليمية :

ه -التقويم : مفهومـه - مواصفاته - معاييره.

إن الغرض من التقويهم مسساعدة كل مـن التلميـذ والملدرس - على السـواء - على معرفة

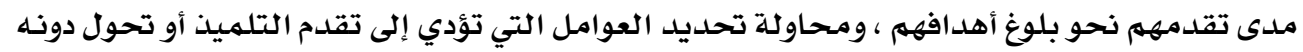

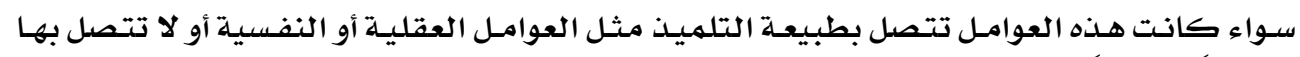

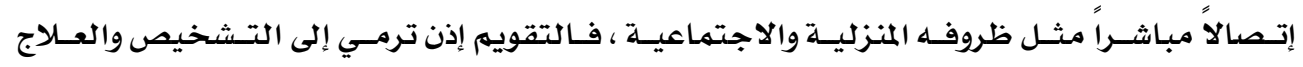
والوقاية. ( خطايبـة، 1997 )

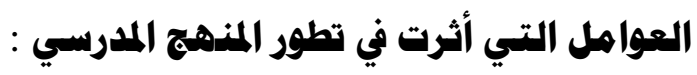

ا ـ اختلاف النظرة الإنسانية.

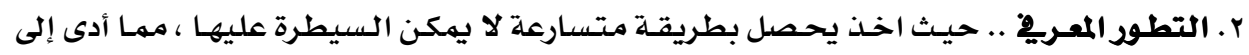

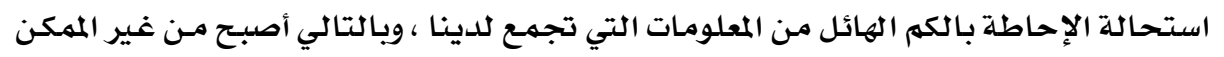

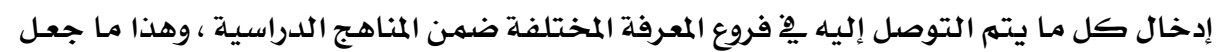

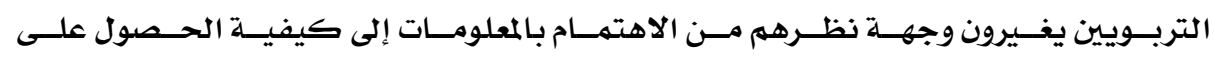
هذه المعلومات المرديات 
r. التطور التكنولوجي .. أدى إلى تغيير النظرة إلى المنهاج فاصبـح البعض ينظر إليها على إنها

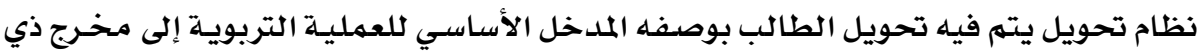

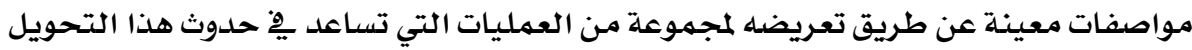
ع. جولات ـِ ثقافة المجتمعات وفكرها الفلسفي والاجتماعي. ه. ن نتائج البحوث التربوية. ( عبد المنعم، 1991) . دواعي تطوير المناهج الدراسية: التطورات اللداخلية "المحلية " :

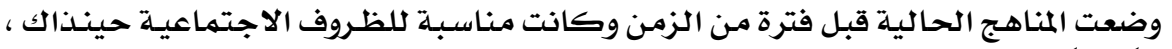

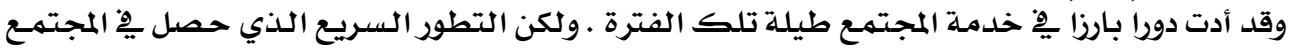

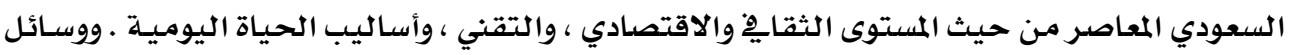

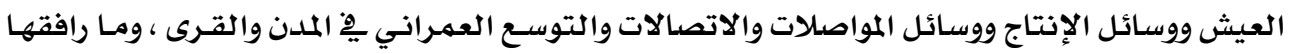

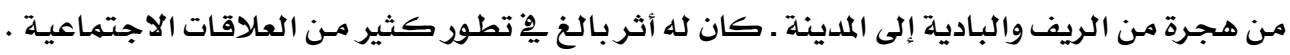

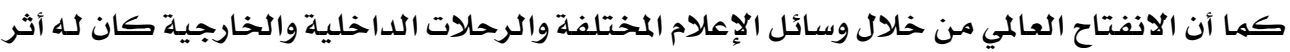

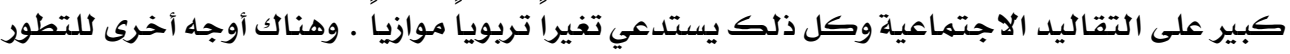

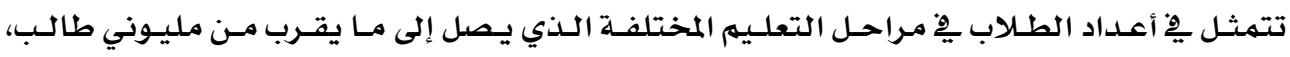

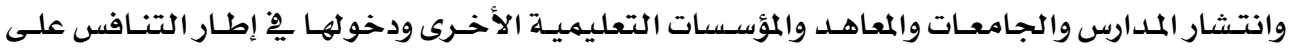

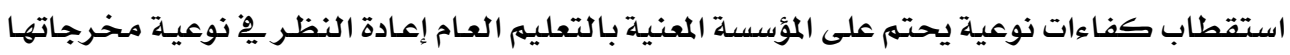

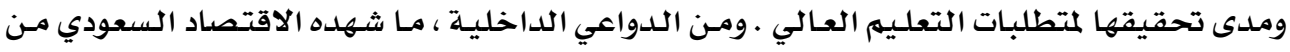

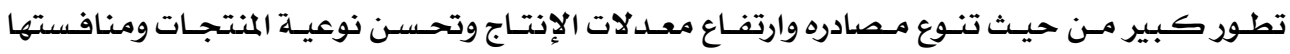

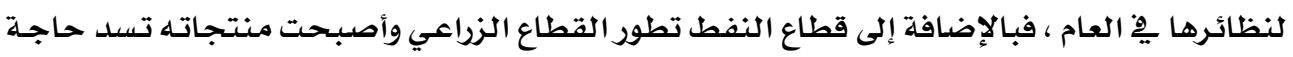

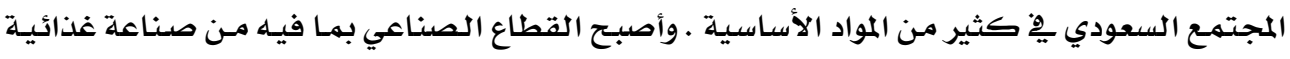

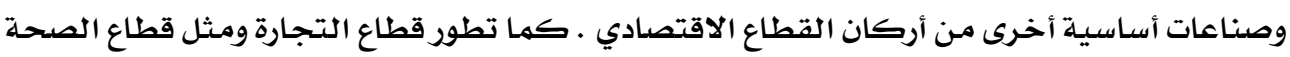

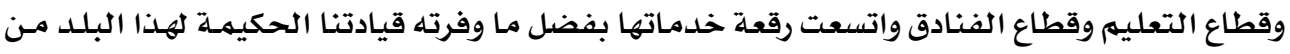

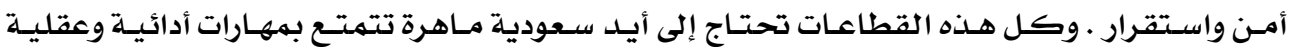

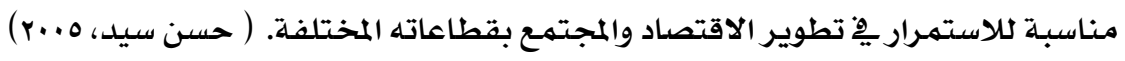

\section{التطورات الخارجية " اللدولية ":}

يـذكر ( Vacc, \&Bright, 1994 أنسه خـلال العقدين الماضيـين حسدثت تطورات عالميـة

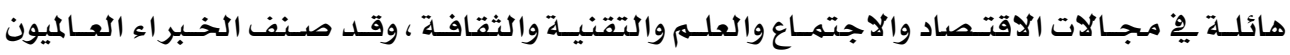

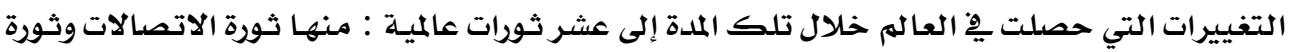

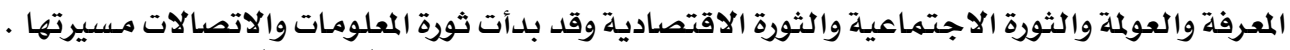

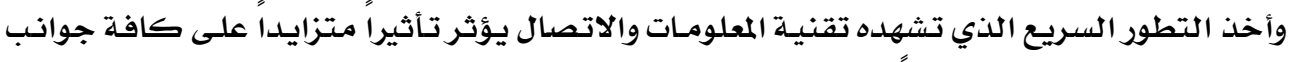

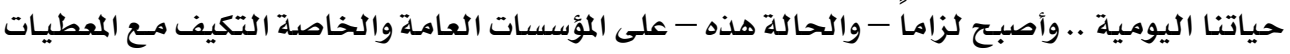




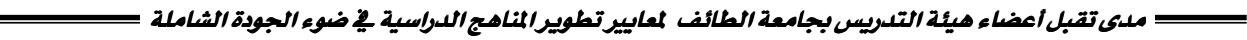

التقنية الجديدة بطريقة تمكنها من الانتفاع بها على الوجه الأكمل وتحد بقدر الإمكان من الأخطار

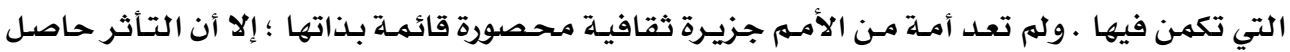
ولو بهقادير يسيرة .

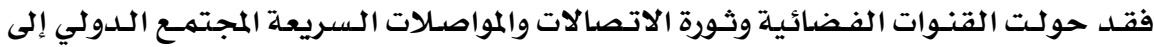

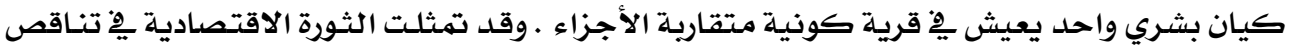

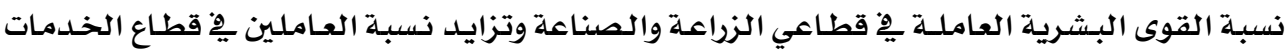

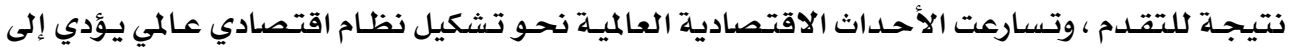

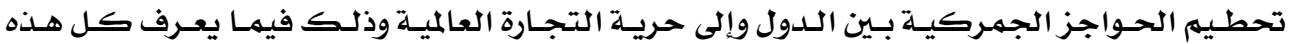

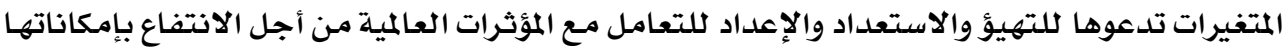

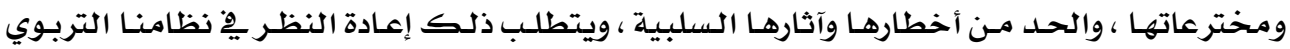

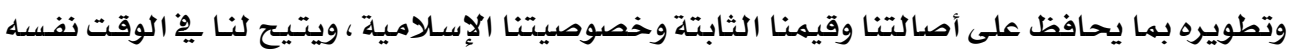

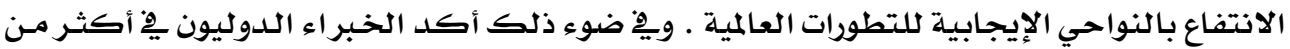

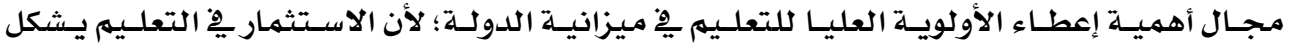

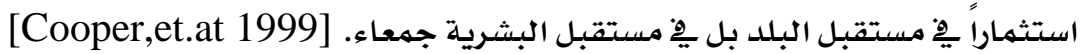

\section{التطورات العلية وتتائج الأبحاث التربوية :}

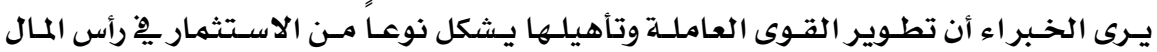

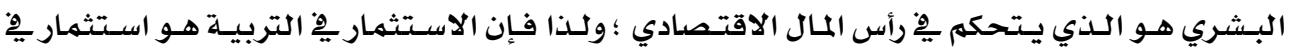

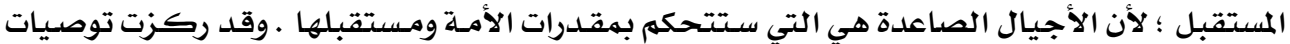

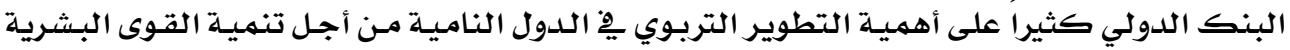

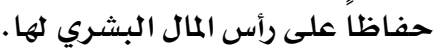

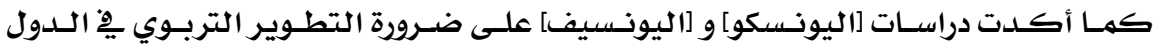

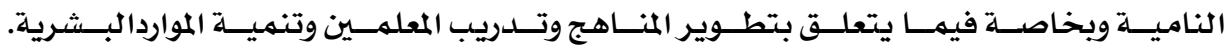

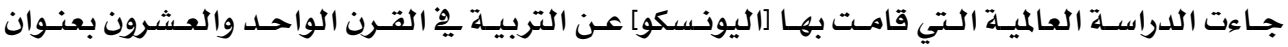

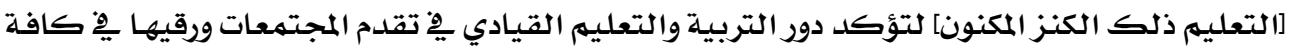

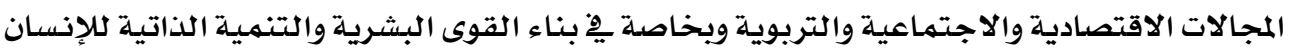

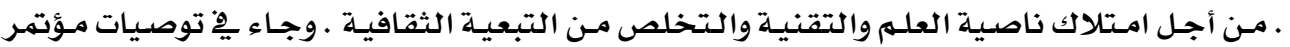

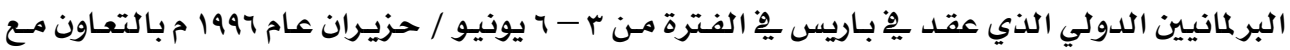

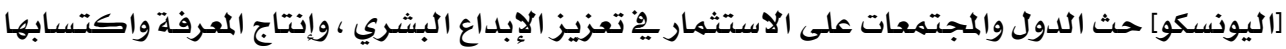

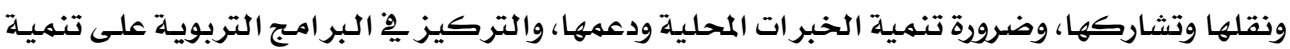

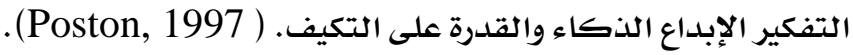
وهناك عدد كبير من الدراسات والتجارب الدولية الحديثة يْ تطوير المناهج منها التجريسة

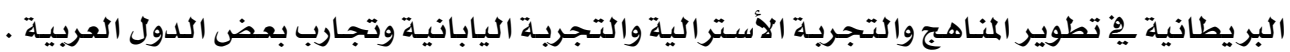




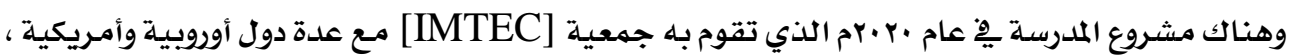

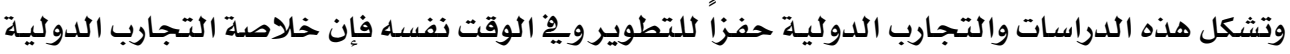
تشكل رافداً من روافد التغيير.

\section{حاجة المناهج الحالية إلى التطوير :}

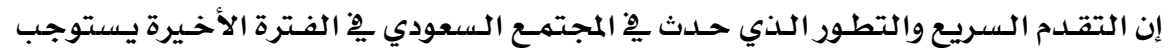

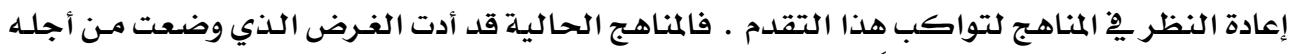

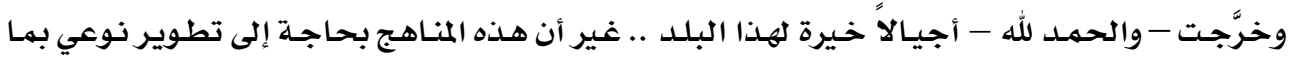

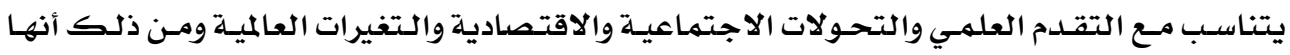

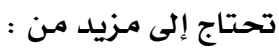

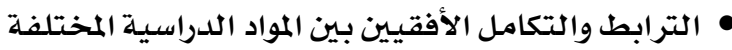

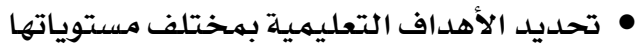

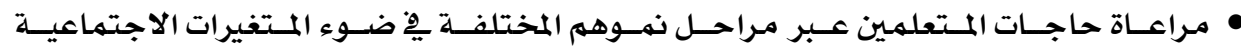

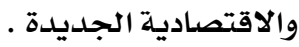

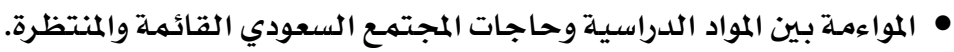

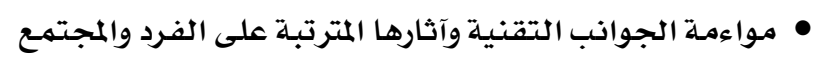

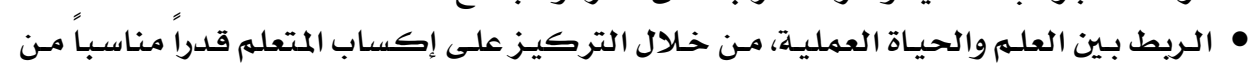
الخبر ات المهنية المختلفة التربن

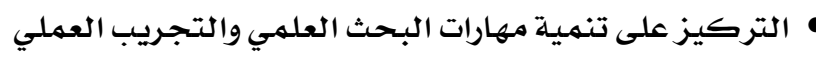

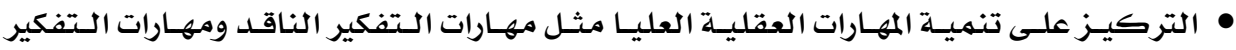

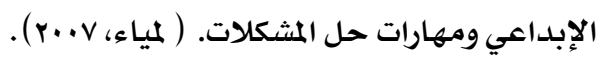
ثانيًا: الجودة الشاهلة: Total Quality

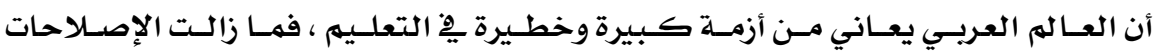

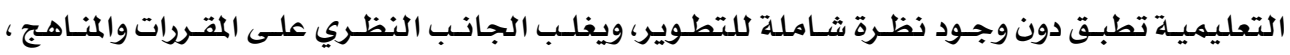

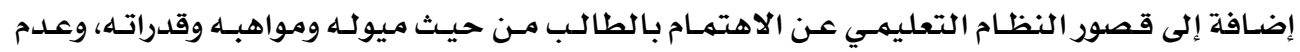

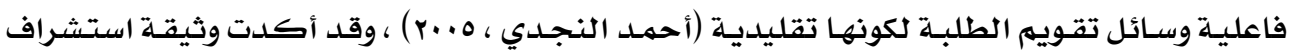

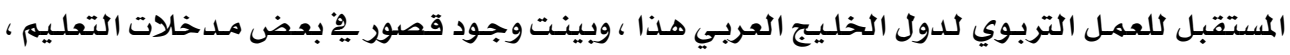

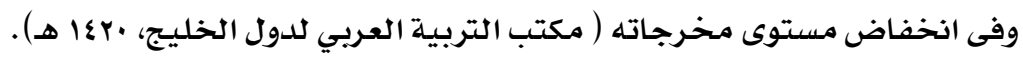

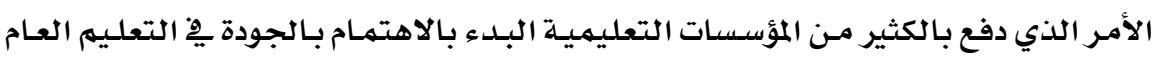

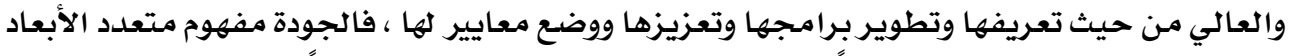

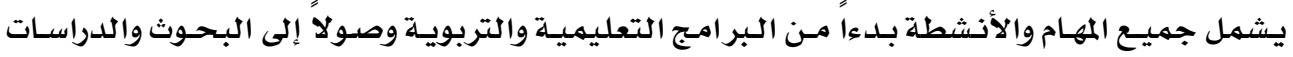

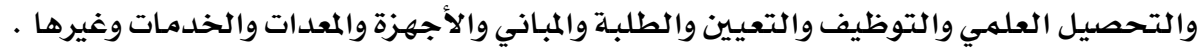




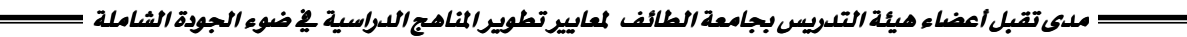

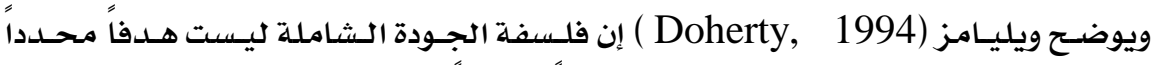

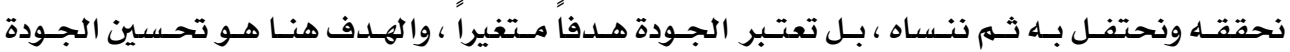

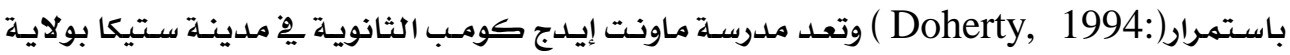

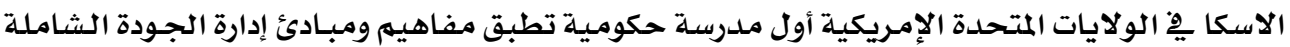

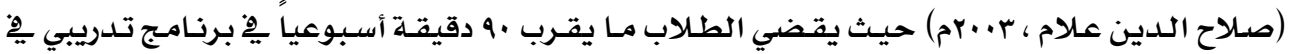

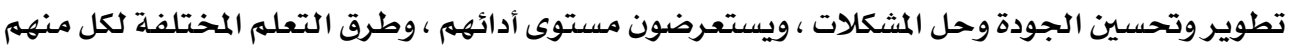

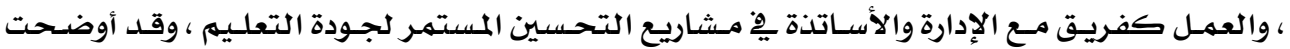

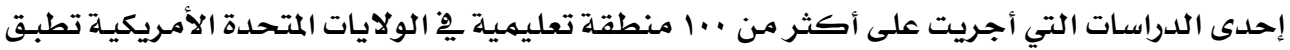

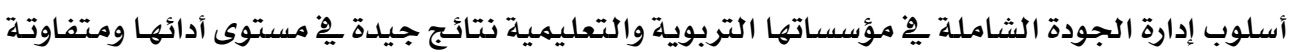
بين بعضها البعض (Campbell,C ., \& Rozsnyai, A. 2002). ولقد تعـددت الآراء والتوقعات حول الجودة ، وهي تختلف بحسب الغايـة والمضمون والزمـن والرؤيا ، وتختلف أيضاً بحسب الأثخاص والفئات المعنيين مباشرة يِّ الجودة (مثل الأهالي ، والمعلمهـين

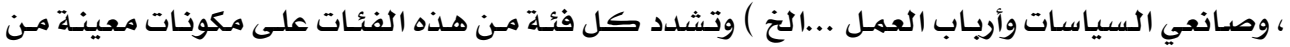

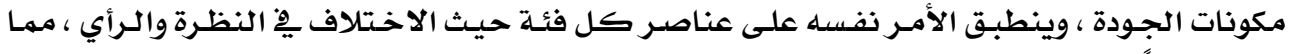

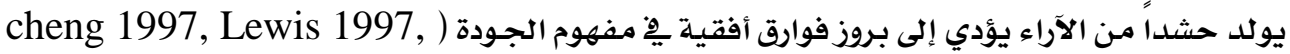
. (Morgan and Murgatroyd, 1994,

وتتكون مواصفات الجودة الرفيعة المستوى يِ التعليهم مـن المشاركة الإيجابيـة لكافة الفـرق

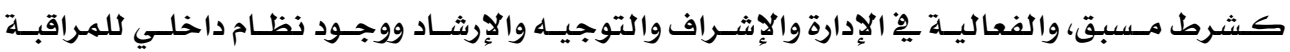

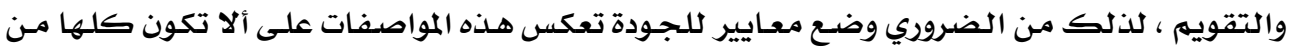

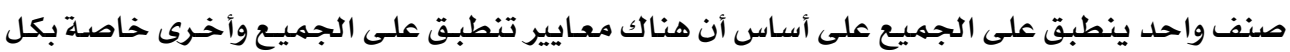

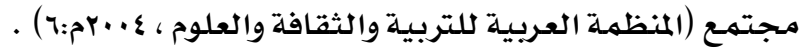

\section{هفهوم الجودة الشاهلة :}

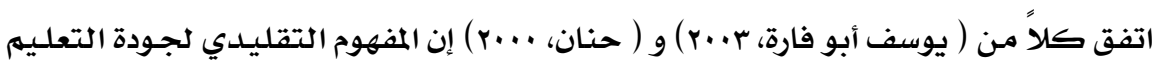

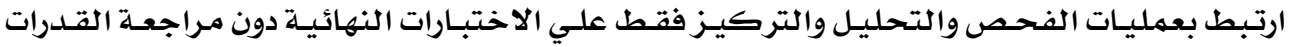

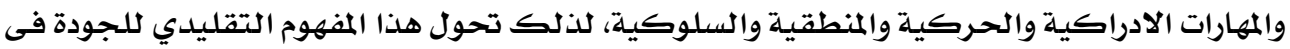

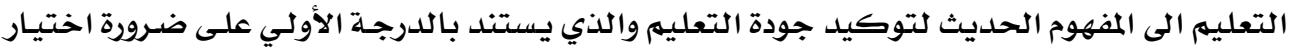

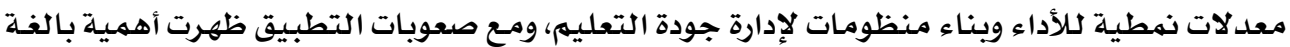

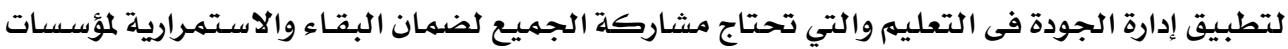

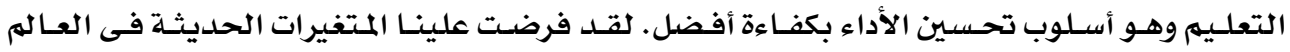

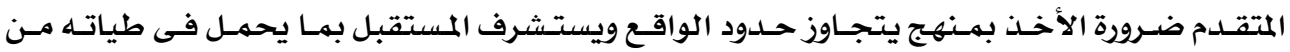

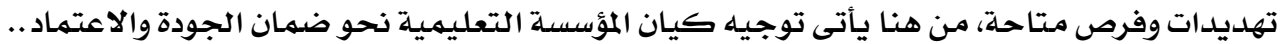


إن مفهوم الجودة وفقا لما تم الاتفاق عليه فى مـؤتمر اليونسكو للتعليهم وأثـار إليـه ( حسـين

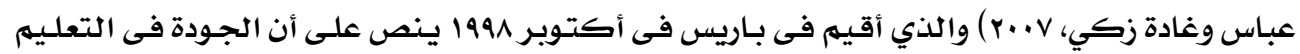

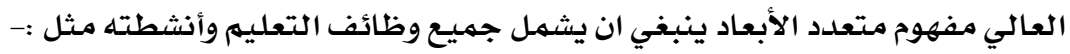

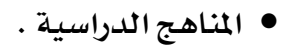

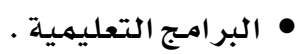

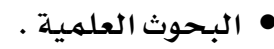

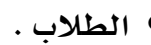

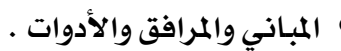

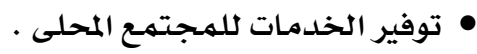

$$
\begin{aligned}
& \text { • • التعليهم الذاتي الداخلي • • } \\
& \text { • تحديد معايير مقارنة للجودة معترف بها دوليه التيا. }
\end{aligned}
$$

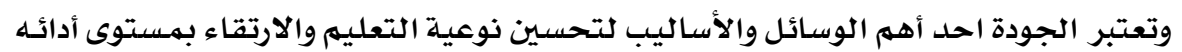

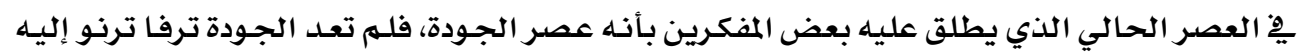

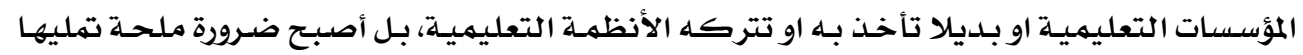

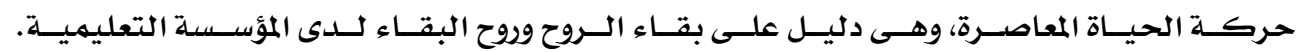

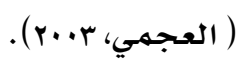

ويشير مصطلح الجـودة إلى تلبيـة حاجـات المستفيد مـن المنتج الدذي تعـده المؤسسـة ، أي المي

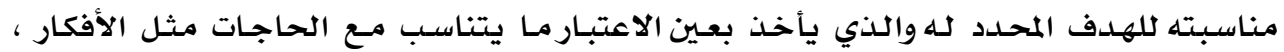

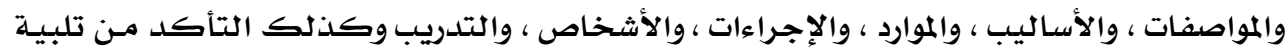

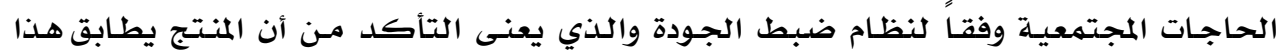

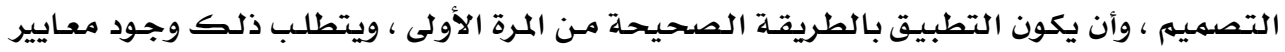

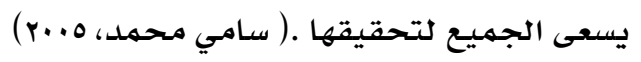

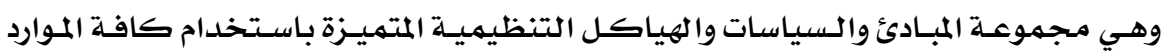

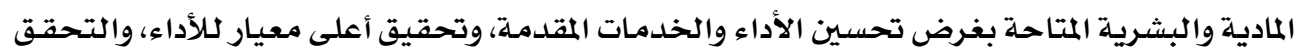

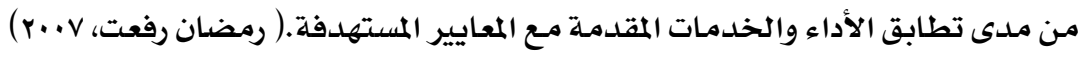
والجودة الشاملة فى التعليم يقصد بها مجموعة من الخصائص أو السمات التي تعبر بدقة

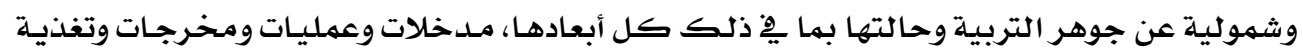

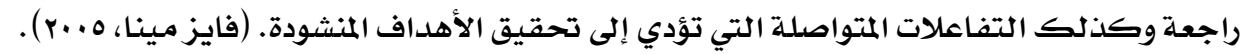




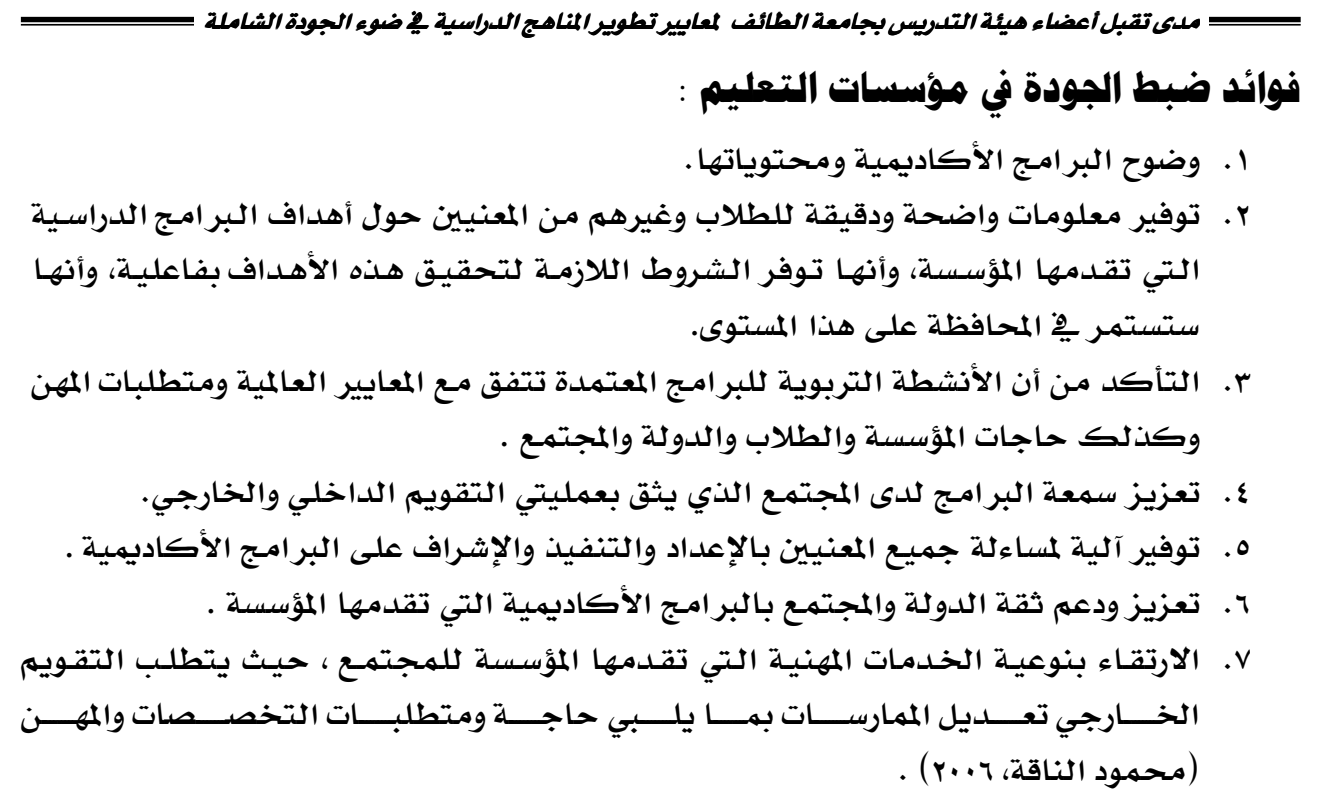

هفاهيم الجودة والاعتمهاد:

يرتبط فكر الاعتماد Accreditation ِِ التعليم العالي ارتباطا وثيقا بمبادئ إدارة الجودة Quality Management Principles

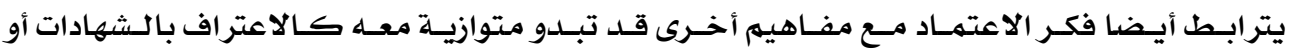

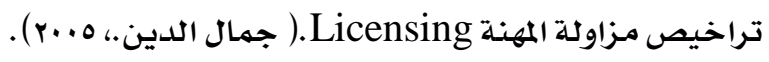

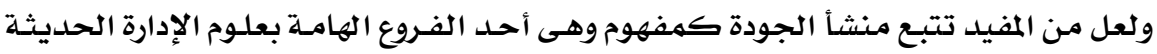

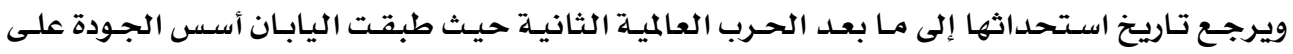

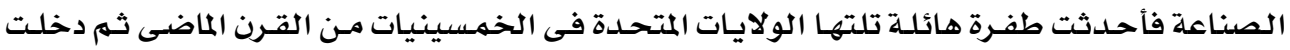

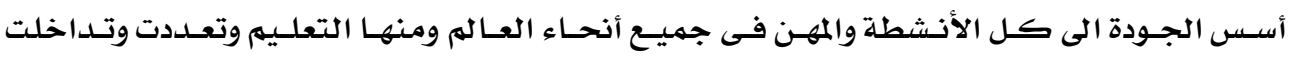
مفاهيمها مما يحدونا إلى محاولة تحديد الانشئ تعريفاتها المتفق عليها الجودة Quality:

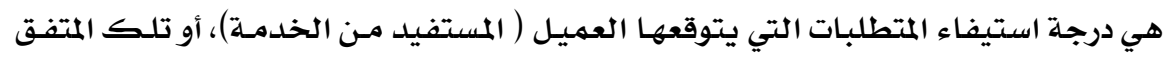

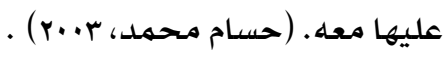
الجودة الشاملة Quality Assurance

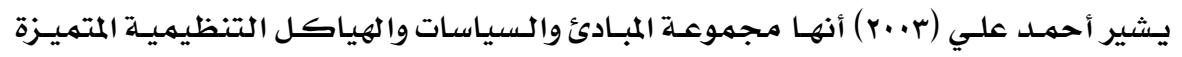

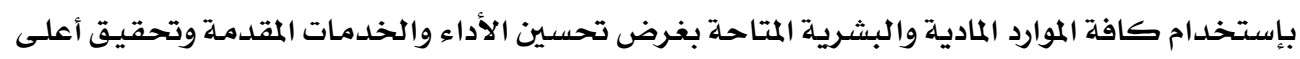

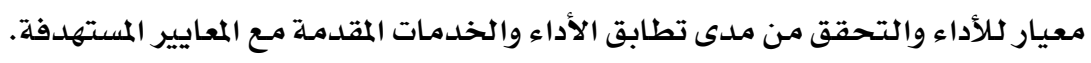

\section{r. 1}




\section{الحاجة إلى ضمان الجودة}

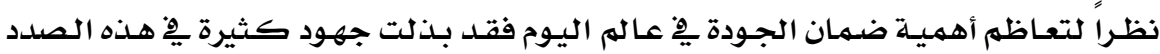

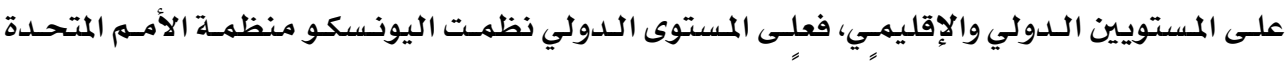

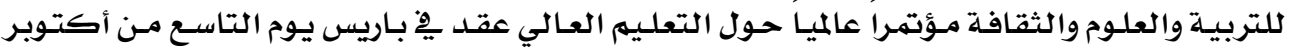
1991، وتم فيـه التركيز على ضـمان الجـودة ولقـد أكدت المادة الحـاديـة عشر مـن الإعلان الصـادر عن هذا المؤتمر على أهمية التقييهم النوعي الذي يتنأول كافة وظـائف وأنشطة التعليهم العالي، واعتبرت

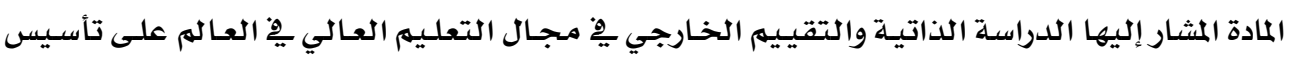
هيئات وطنيـة مستقلة، ووضـع معايير ومستويـات دولية لضهمان الجودة، كما أكد الإعلان على أهميـة

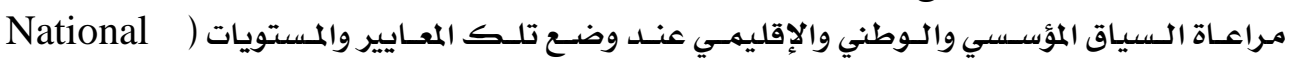
.Quality Assurance and Accreditation, 2004 أما على المستوى الإقليمي، فقد أشـار المؤتهر العالمي إلى عدة أنشطة إقليميـة، ففي بيروت -

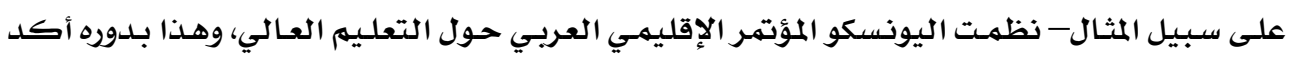

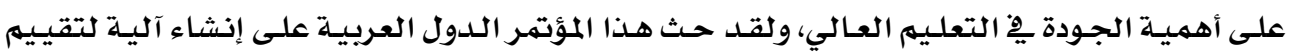

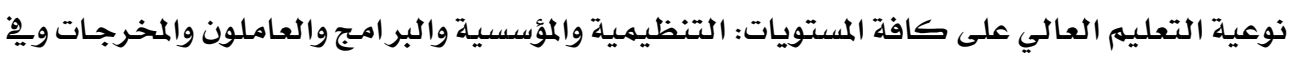

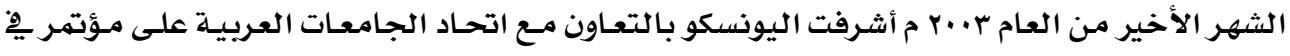

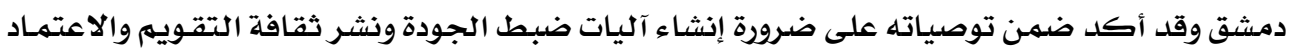

مِ الجامعات العربية (National Quality Assurance and Accreditation, 2004).

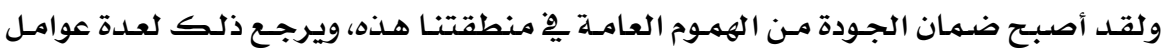

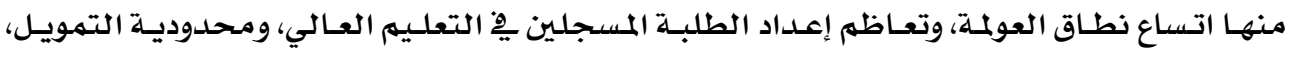

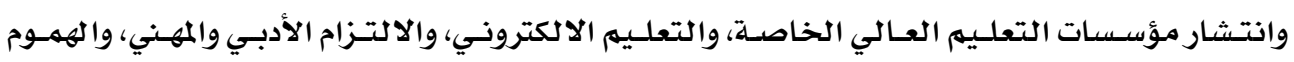

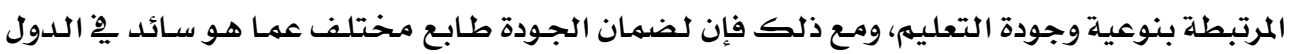

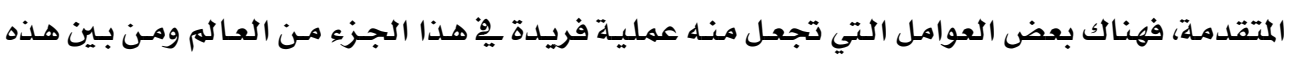

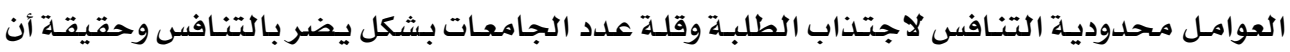

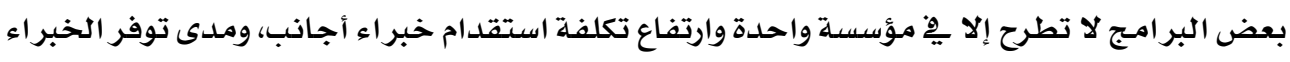

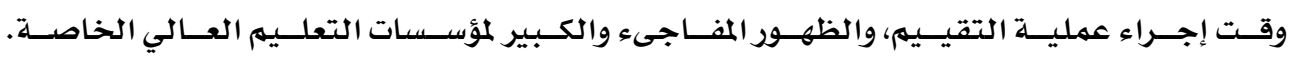

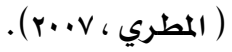

\section{هتطلبات إدارة الجمددة الشاملة في التعليم العالي}

ا ـ دعم الإدارة العليا: إن دعم تطبيق إدارة الجودة الشاملة يحتاج إلى دعم ومؤازرة من الإدارة العليا

$$
\text { كتحقيق الأهداف المرجوة. }
$$

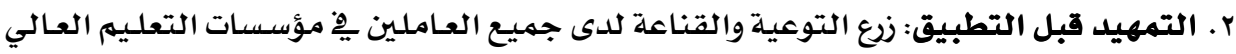

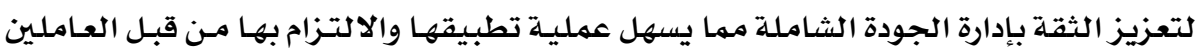

$$
\text { بمؤسسات التعليم العالي. }
$$


r. توحيد العمليات: إن توحيد العمليات يرفع من مستوى جودة الأداء ويجعله يتم بطريقة أسهل

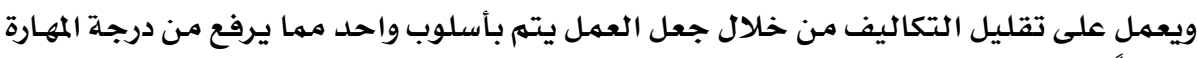

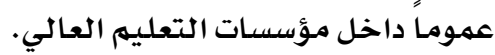

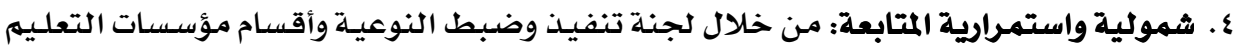

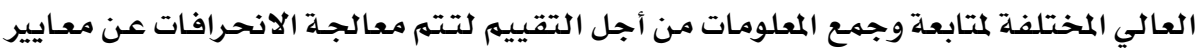
التطوير.

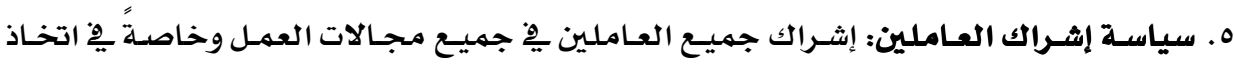
القرارات وحل المشاكل وعمليات التحسين.

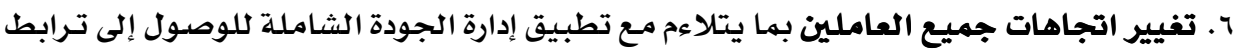

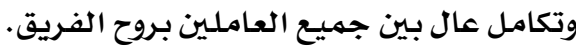

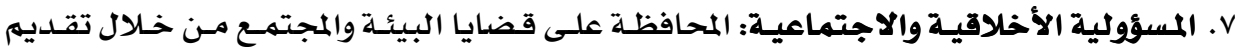

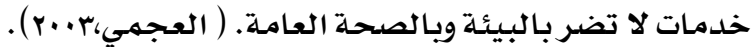

\section{ضمان الجودة هن هنظور الجاهعات العربية}

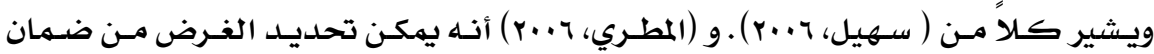
الجودة من منظور الجامعات العربية فيما يلي: • ضوفمان الوضوح والشفافية للبر امج الأكاديهية.

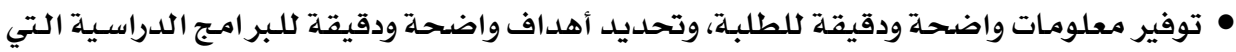

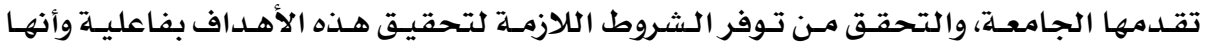

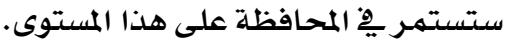

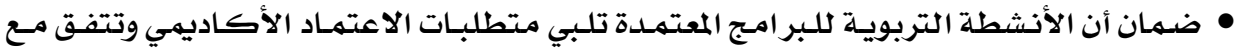

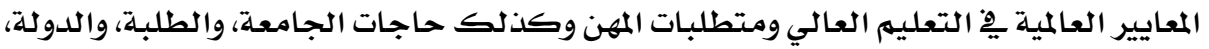

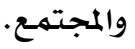

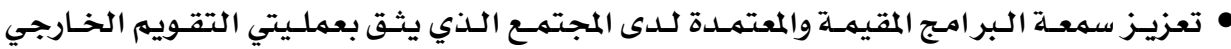
والاعتماد الأكاديهي. • توفير آلية بمساءلة جميع المعنيين بالإعداد والادئ والتنفيذ والإثراف على البر امـج الأكاديمية.

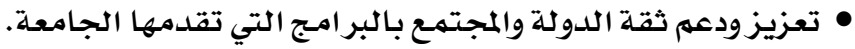

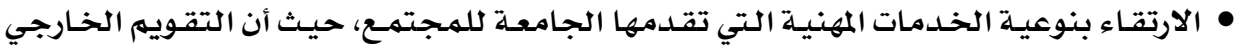

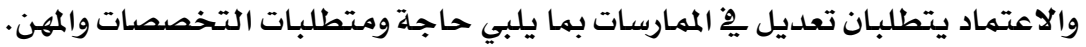

\section{ضهان الجودة في تطاع التعليم العالي:}

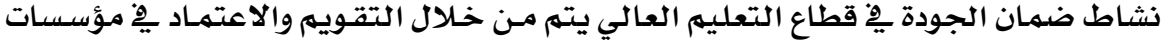

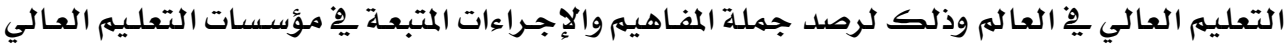

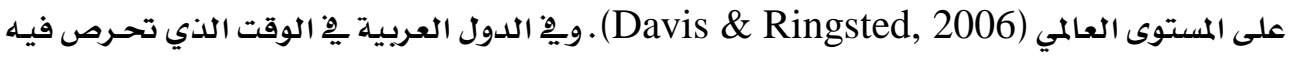




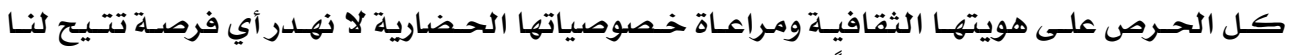

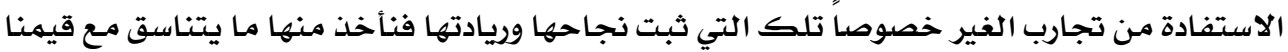

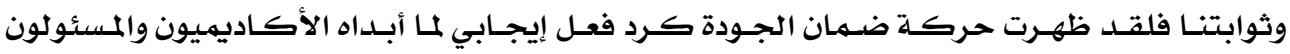

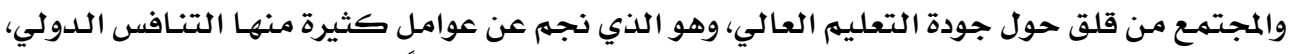

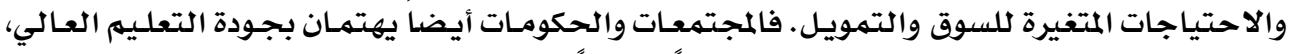

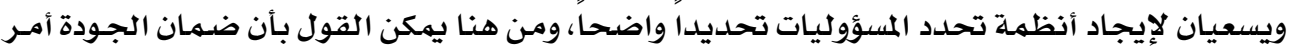

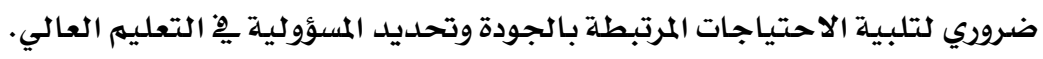

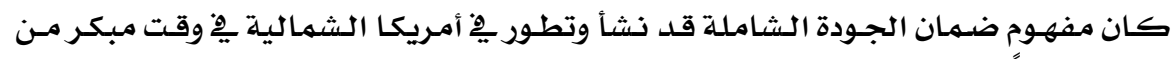

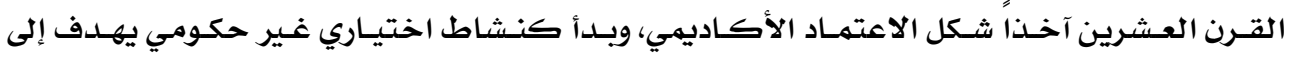

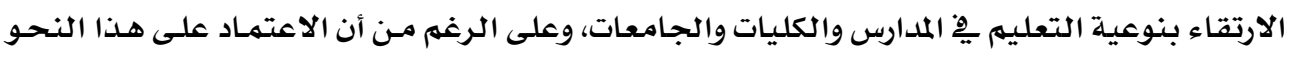

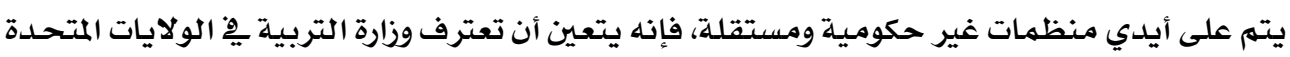

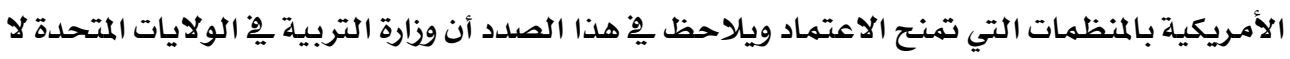

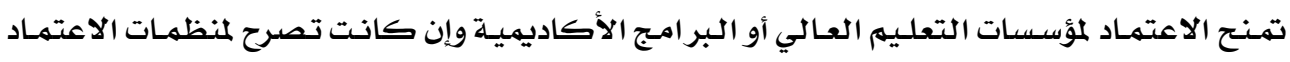

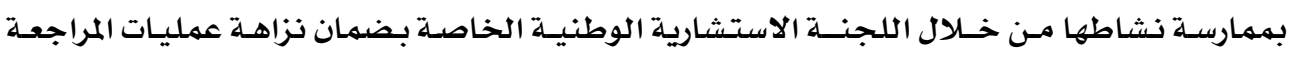

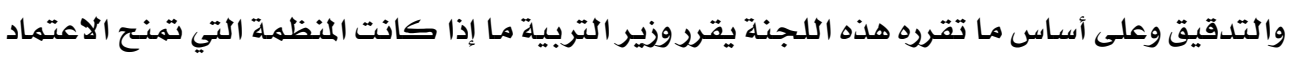

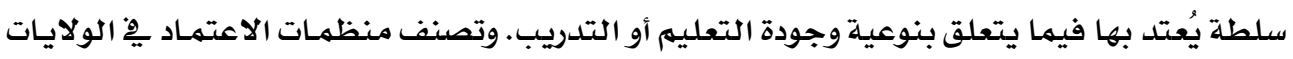

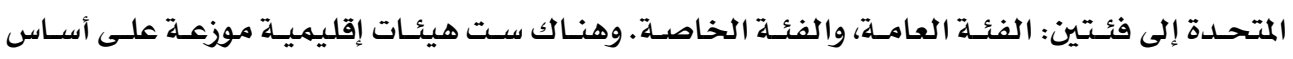

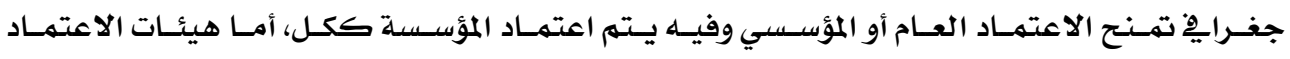

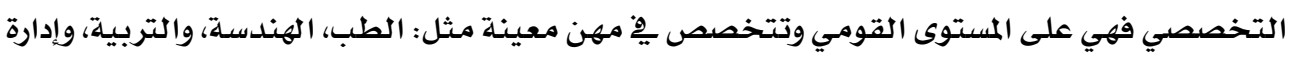

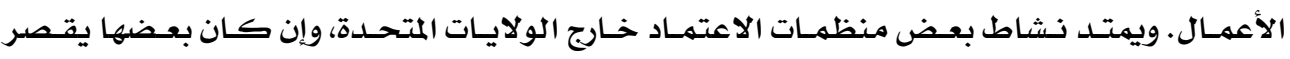

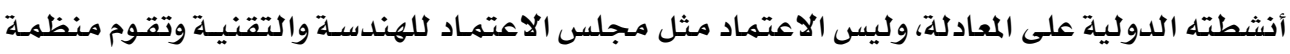

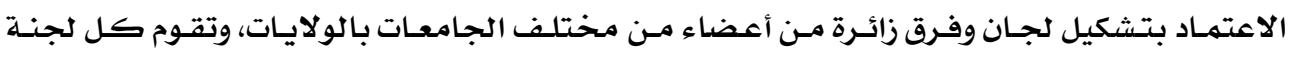

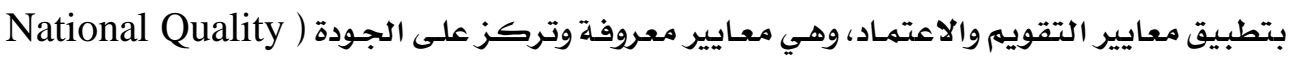
.) Assurance and Accreditation, 2004

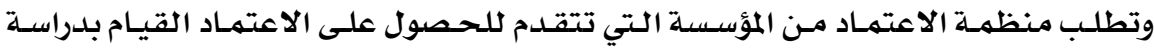

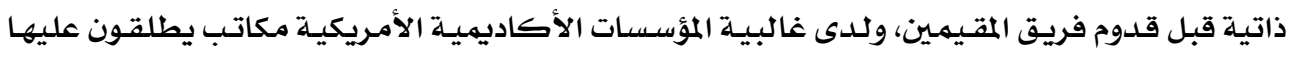

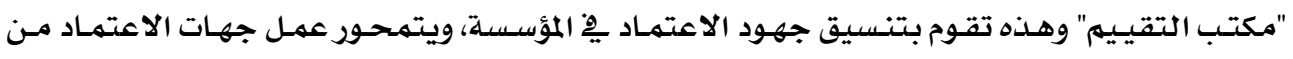

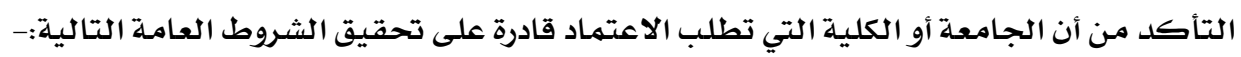

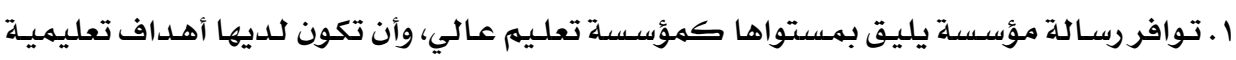

$$
\text { تتفق مع رسالتها. }
$$

r. امتلاك المصادر والموارد المناسبة لتحقيق الرسالة والأهداف التعليمية. 
ب. تـوافر نظـام توثيـق أعمـال الطلبـة المتـصلة بالأهــاف التعليميـة بهـا يـبـين أن المؤسســة تحقـق

أهدافها.

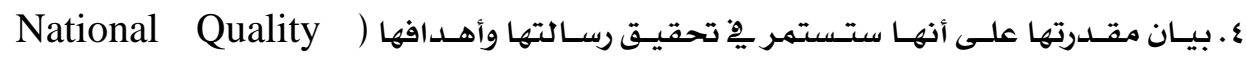

.(Assurance and Accreditation, 2004

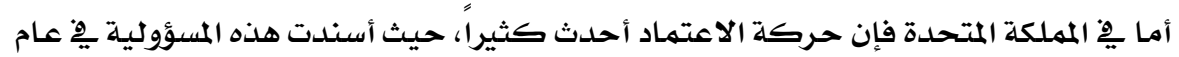

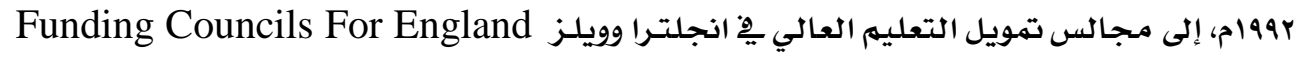
and Wales Higher Education

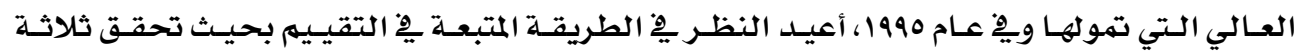

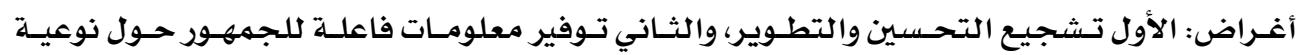

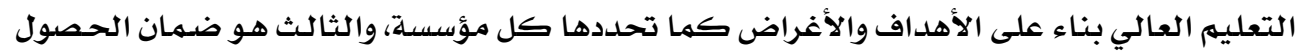

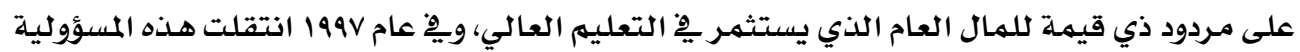

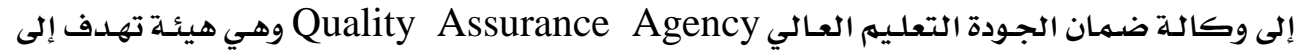

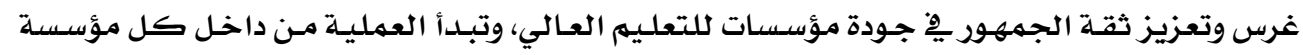

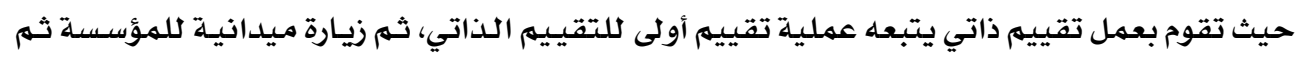

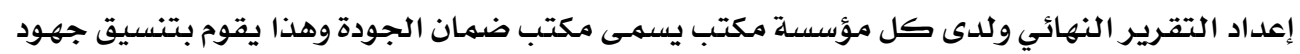
التقييم بها (UK National Accreditation, 2004).

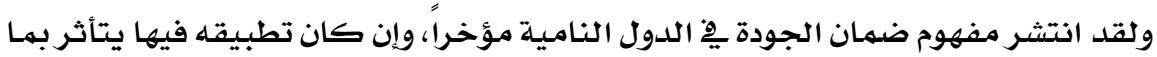

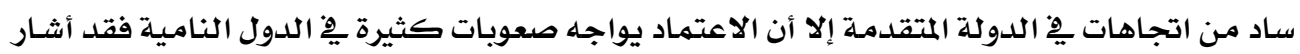

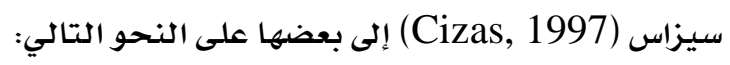
• أولاً: تطرح بعض البر امـج بواسطة مؤسسة واحدة فحسب. • ثـانياً: قد لا يتوفر خبر اء أجانب وقت إجراء عملية التقييم.

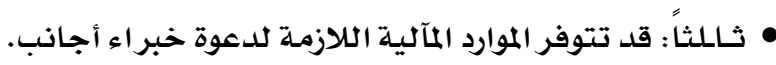

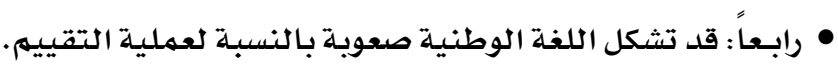

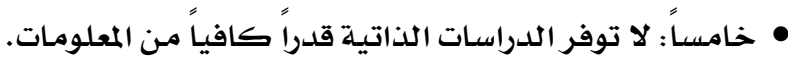
• سـادساً: قد لا يتوفر مقيمون خارجيون محايدون.

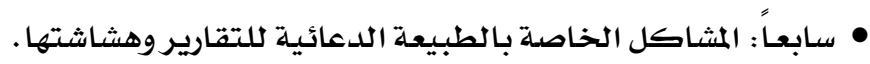

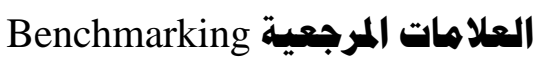

هي وسيلة نظامية لقياس ومقارنة أداء أى مؤسسـة تعليمية استناداً إلى منظومـة من المعايير

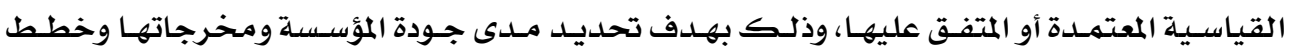

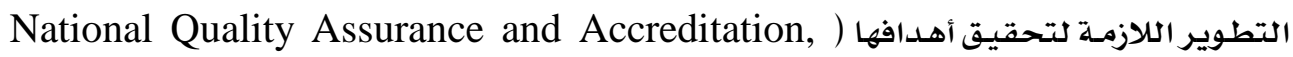


هو نشاط مؤسسي علمي موجهه نحو النهوض والارتقاء بهستوى مؤسسات التعليهم والبر امـج

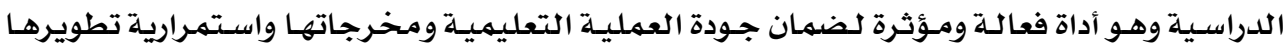
.(National Quality Assurance and Accreditation, 2004) Accreditation Standard المعيار في الاعتهاد

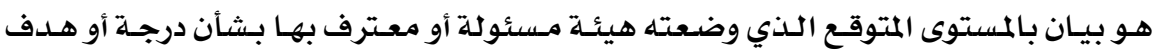

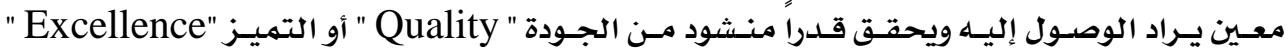
.(National Quality Assurance and Accreditation, 2004) Accreditation in Education الاعتماد في التعمايـم أثـارديفيد وهارولد وديفيذ ورينجستد ) David \& Harold, 2000; Davis \& (Donnelly, 2006

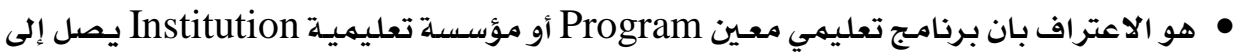

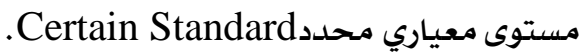

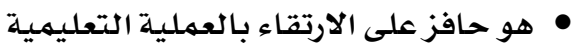

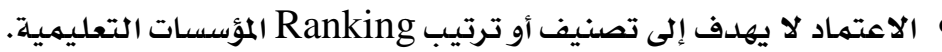

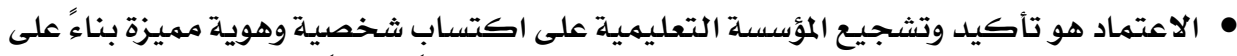

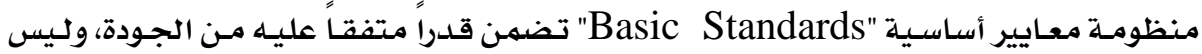
طمسا للهوية الخاصة بها.

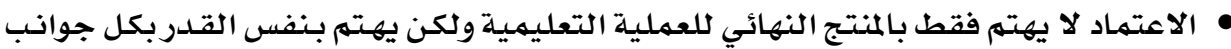

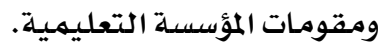
أنواع الاعتماد: ا. الاعتمـاد المؤسسي: "Institutional Accreditation" وهو الدني يركز على تقييم الأداء بالمؤسسة التعليمية بصورة شاملة العوسية. r. الاعتماد التخصصي:"Subject Accreditation" وهو الذني يركز على الاهتمـام بـالبر امـج الأكاديمية التخصصية التي تطرحها المؤسسة بشكل منفرد (Cizas, 1997).

مفهوم ضبط النوعية Quality Control

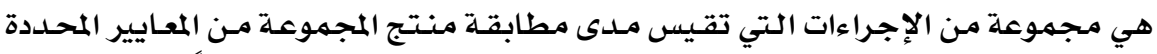

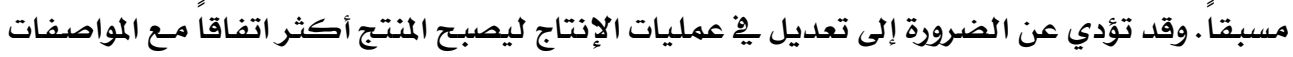
المرسومـة (David \& Harold, 2000). 
Quality assurance مفوم ضمان النوعية

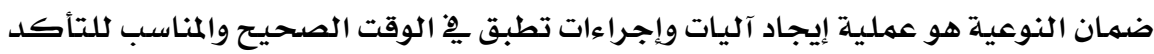

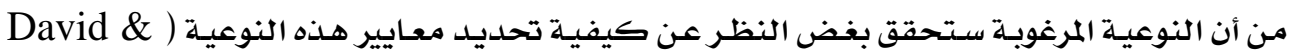
.(Harold, 2000

\section{المعايير الواجب إتباعها لتقييه جودة العملية التعليمية:}

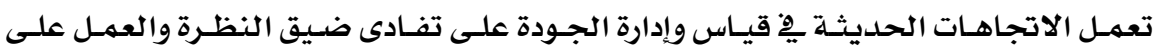

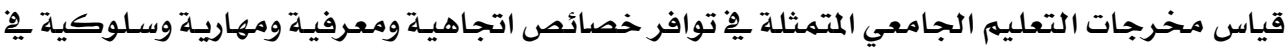

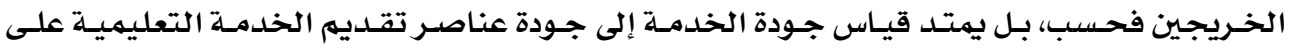

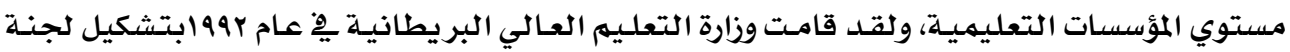

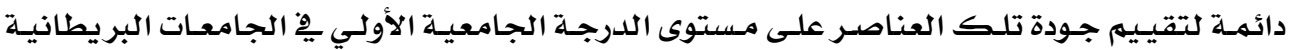
(David \& Harold, 2000; Calpin-Davies \& Donnelly, 2006)

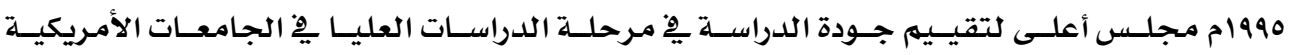
.(National Quality Assurance and Accreditation, 2004) ثالثًا: المعايير Standards

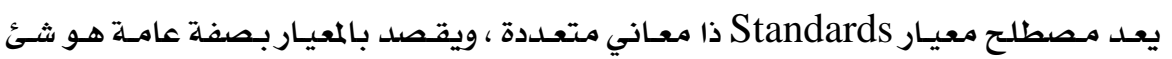

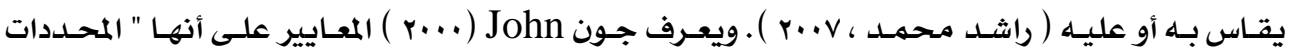

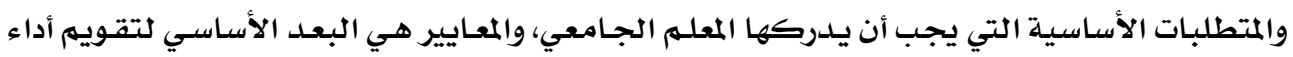

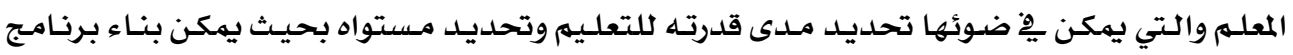

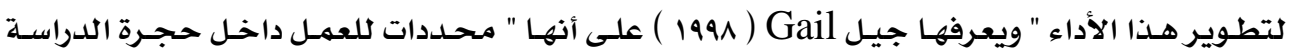

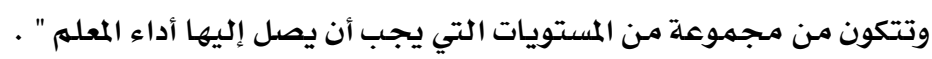

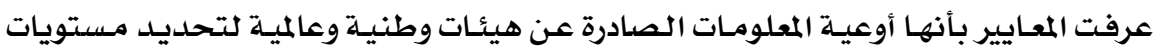
محددة لتحقيق أهداف المؤسسات بأكثر مصداقية. (محمد عبد المعات الرازق، ب.. r)

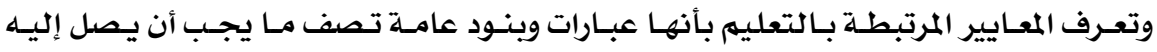

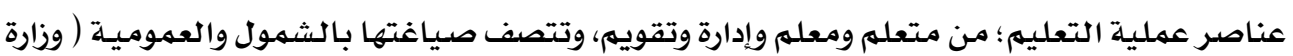

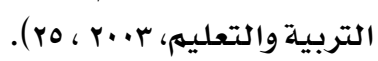

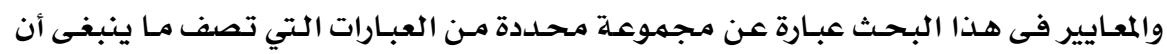

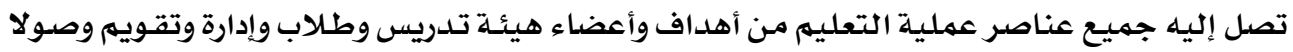
لتوفير أفضل أداء وإنجاز أكبر عائد تعليمي.

\section{وللمعايير أهمية خاصة وذلك للأسباب الآتية:}

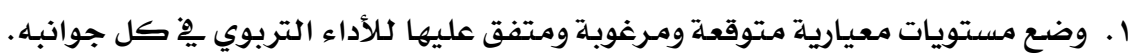

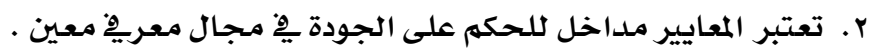




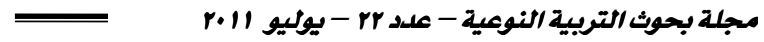

r. مـ الناحية المثالية فإن المتعلمـين يتعلمون أفضل يِّ بيئة تقوم على أساس المعايير

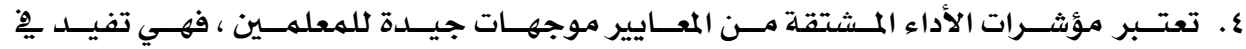

التخطيط للتدريس.

ه. تضمن المعايير استمرارية الخبرة ، فكل الجهود تتظافر لتحقيق المعايير على طول مسار التعله

$$
\text { من صف إلى آخر ، ومـن مـرحلة إلى مـرحلة أخرى . }
$$

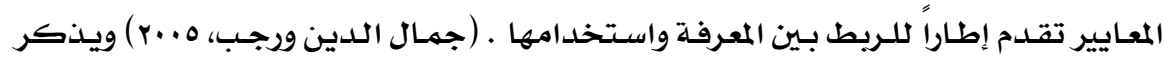

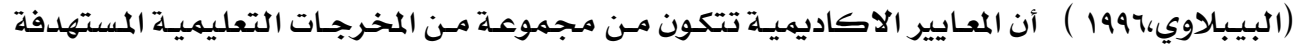

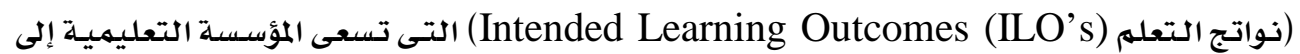

اكسـابها للطلاب عند اكما لهم للبر نامسج الاكاديهى، وتشهل:

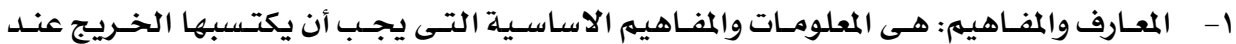

$$
\text { اكمال البرنامـج الدراسي. }
$$

r- المهارات الذهنيـة: مـا تم اكتسـابه وفهمهه من المعلومات والمفاهيه النظريـة السـابقة، مثل مهارة التحليل والتركيب والاستتتاج والابتكار وتحديد المشكلات وايجاد الحلول. ب- المهارات العمليـة (المهنية) : القلدرة على توظيف المهارات الذهنيـة السـابقة فى تطبيقـات مهنيـة، مثل قياس الذكاء واعداد وتصميهم خرائط.

ع- المهارات العامـة: المهارات المختلفة التى يمكن الاستفادة منها فى مجاءلات عملية مختتلفة، وهىى غير مختصدة بمادة الدراسة أو التخصص، مثل مهارات الحاسب الآلى والتعلم الذاتى ومهارات الاتصال ومهارة العمل فى فريق ومهارة الادارة.

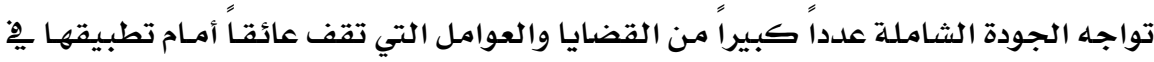
معوقات الجودة الشاملة في التعليم: المؤسسـات التعليميـة ، وتلك المعوقات تحـول دون تطبيـق معاييرهـا ومؤشـراتها ، وتتبـاين تلـك المعوقـات

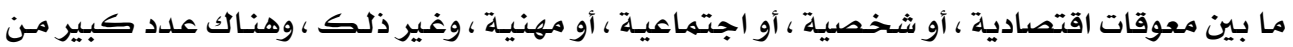

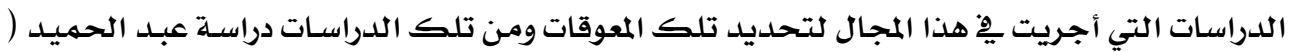

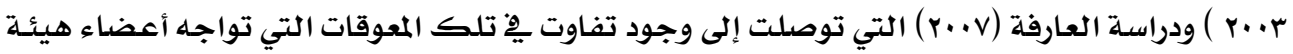
التدريس وقد جاءت بالترتيب كالآتي :

المعوقات الاقتصـادية ، ثم المعوقات الشخصية ، ثم المعوقات الاجتماعية ، ثم المعوقات المهنية ، وأخيراً المعوقات البحثية .

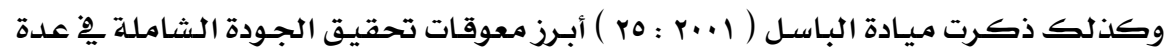
نقاط وهي :

صعوبة تحلديد الأولويات بين الخدمات الواجب توافرها ، كما يصعب تحديـد معـايير قيـاس

مدى جودتها . مدى . 


$$
\text { التركيز على تقييم الأداء ، وليس على القيادة الواعية . }
$$

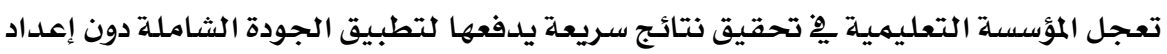

$$
\text { البيئة الملائمسة لتقبلها. }
$$

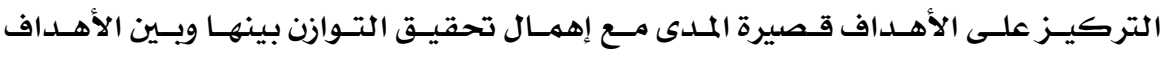

$$
\text { طويلة الأجل . التركز }
$$

عدم الاتصال الكـايخ للمستفيدين مـن العمليـة التعليميـة والعـاملين بالمؤسسـات التعليميـة

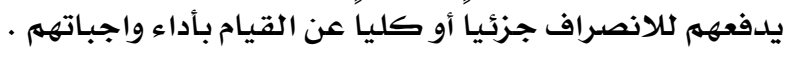

ندرة البيانات والمعلومات المتوفرة عن النظام التعليمي ، وكذلك عن الإنجازات المحققة إتباع أنظمة وسياسات وممارسات لا تتسق ومدخل الجودة الشاملة . اللّبس المتعلق بالتدريب وتقييم الأداء ، وما يصاحب ذلك من إهمال الهال الاحتياجـات التدريبيـة

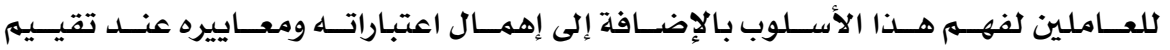

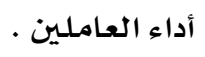

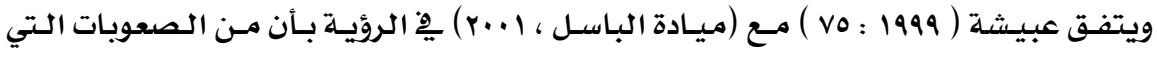

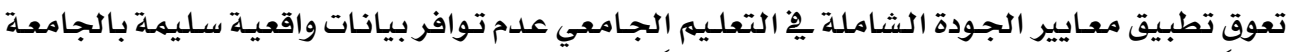

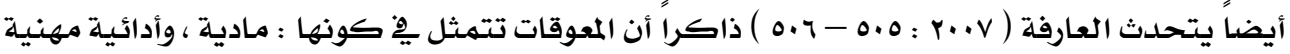

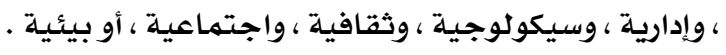

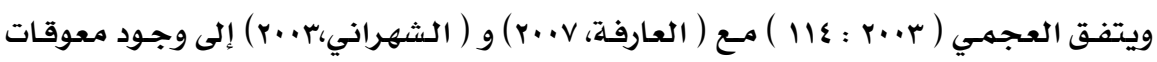

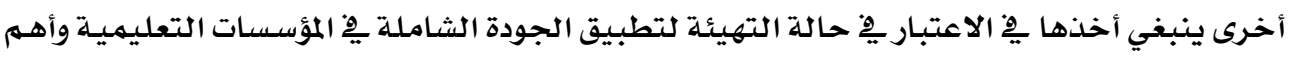
تلك المعوقات :

اختلاف نوعية العميل بالنسبة للمنتج بين : تعليم الطالب ، وولي الأمر ، والموظف المستقبلي

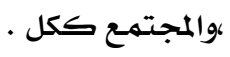

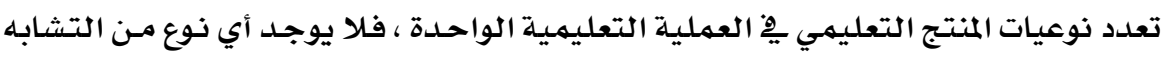

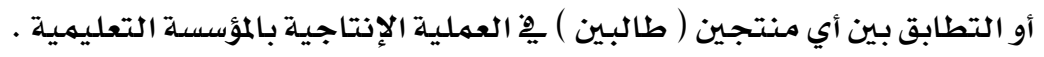
عدم إمكانية التحكم الكامل ِِف مدخلات العملية التعليمية من أجل إعداد المنتج التعليمي .

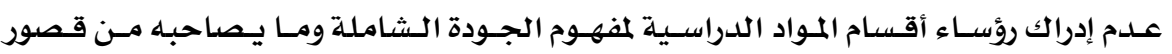

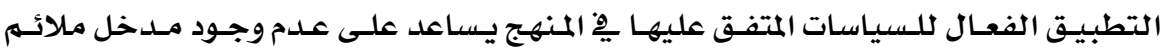

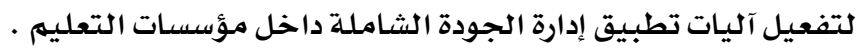
عدم وجـود رؤيسة مشتركة بـين جميـع العـاملين عن المقصود بـالجودة الشاملة ، وعناصـرها ، وكيفية تحسينها. 


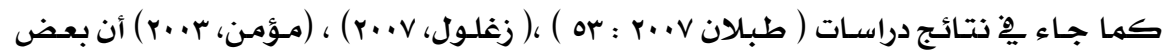
معوقات الجودة الشاملة والمرتبطة بعضو هيئة التدريس والتي عبر عنها بالصعوبات داءل كالتالي :

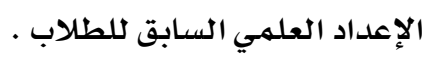

النظام لا يراعي الفروق بين الطلاب من حيث التفرغ للدراسة والخبر ات العلمية السـابقة.

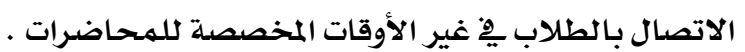

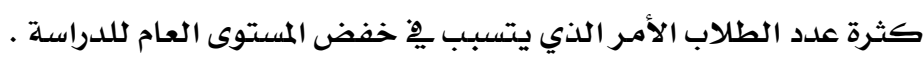

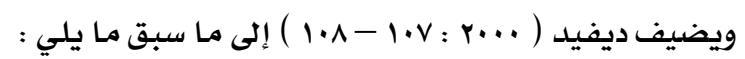

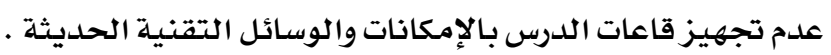
اعتماد تدريس المقرر على المذكرة أو الكتاب الجامعي .

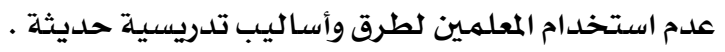

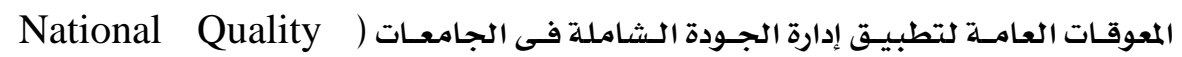

(Assurance and Accreditation, 2004

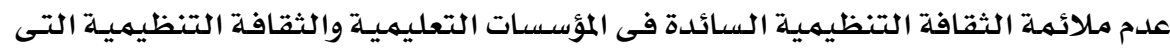

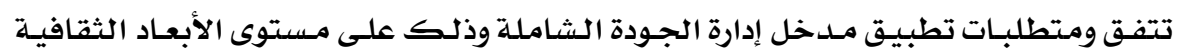

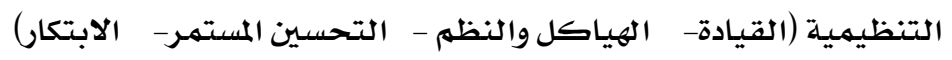

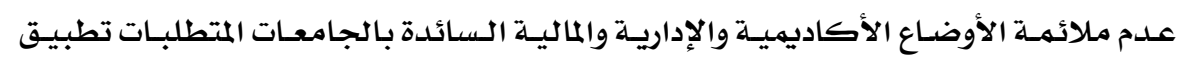

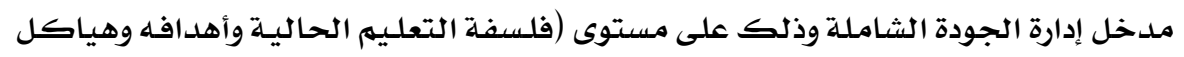

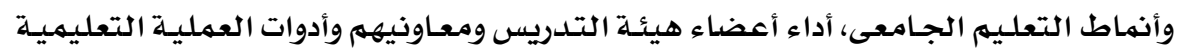

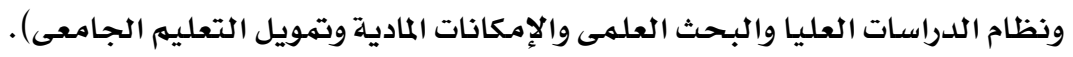
عدم مشاركة جميع العاملين يِّ تطبيق إدارة الجودة الشاملة.

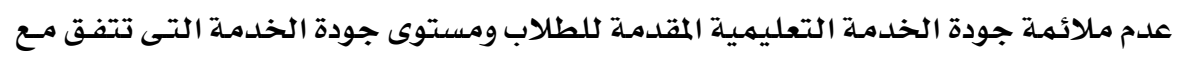

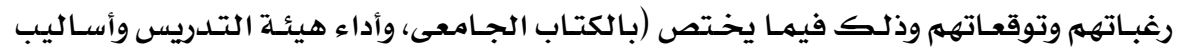

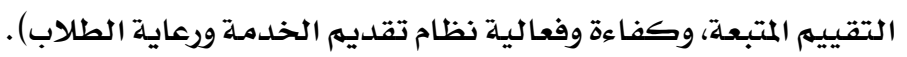
عدم الربط بين الكليات بالجامعة وقطاعات سوق العمل من حيث (مـدى تطور المنـاهج طبقِاٍ

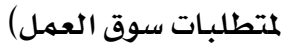
تبني طرق وأساليب لإدارة الجودة الشاملة لا تتوافق مـع خصوصيلة المؤسسـة. مقأومـة التغيير سواء من العاملين أو من الإدارات وخاصة الاتجاهات عند الإدارارات الوسطي. توقع نتائج فورية وليست على المدى البعيد. 


\section{الدراسات السابقة:}

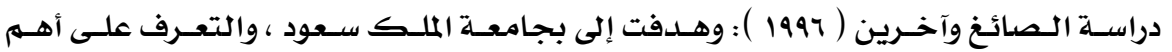

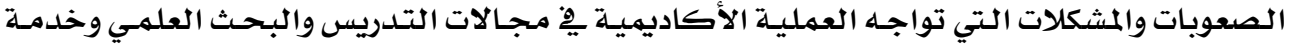

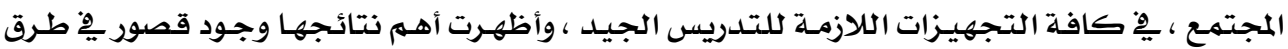

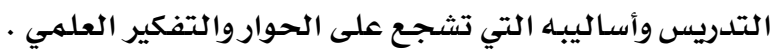

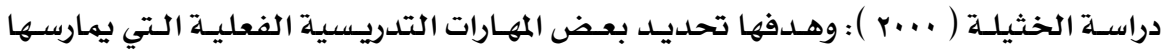

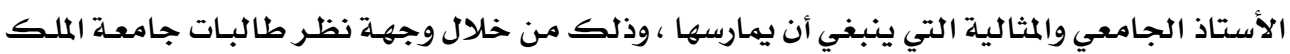

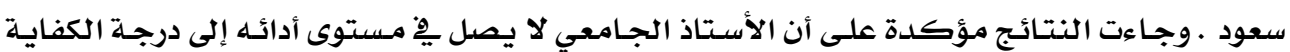

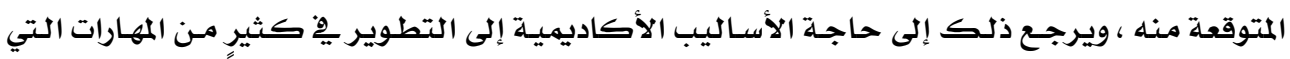

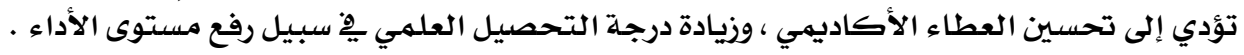

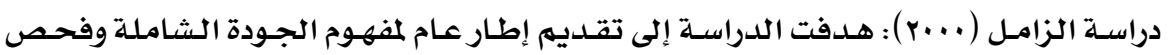

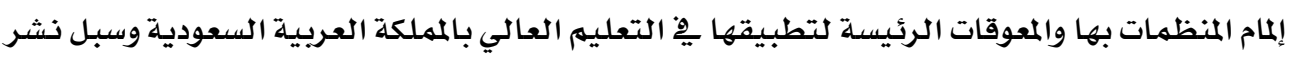

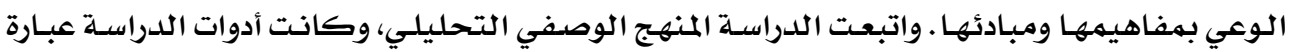

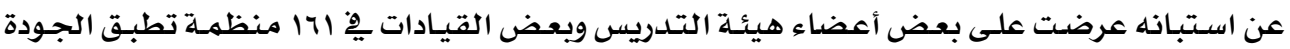

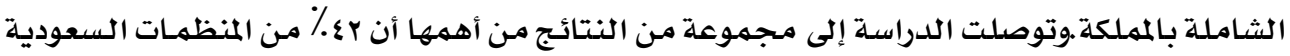

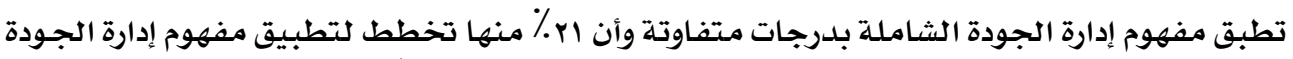

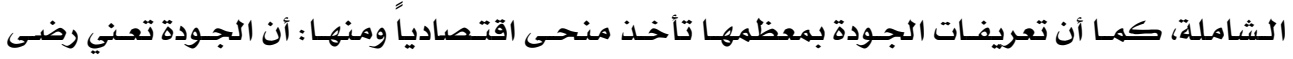

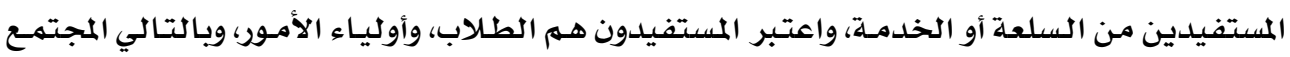

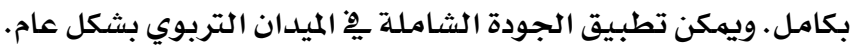

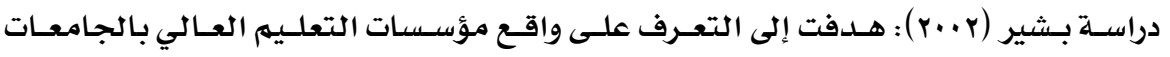

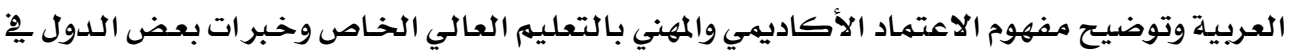

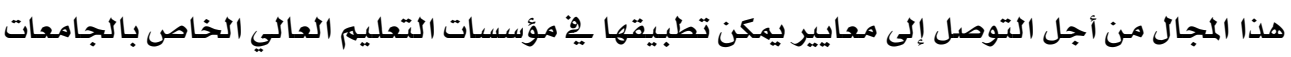

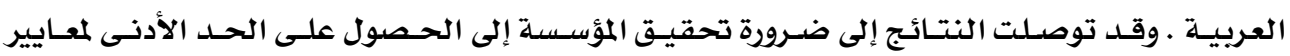

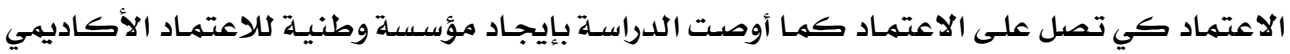

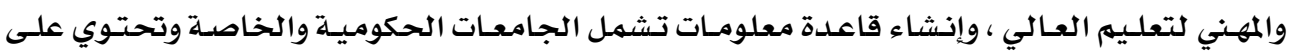

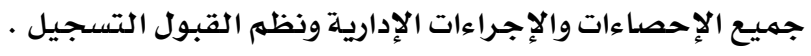

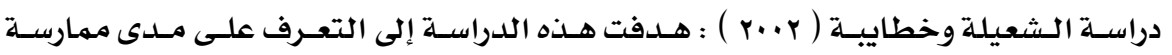

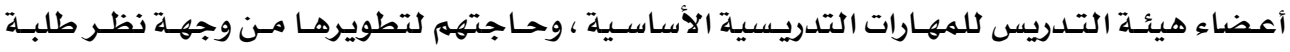

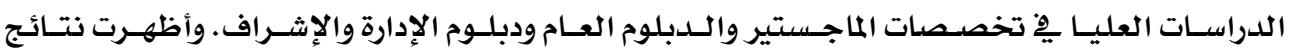

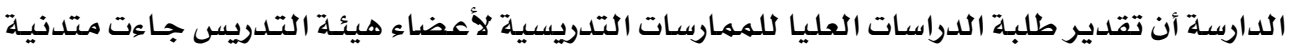

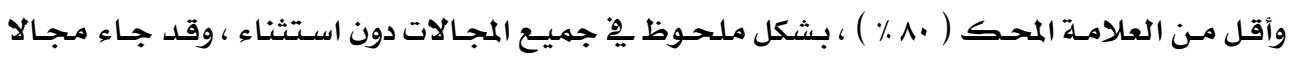




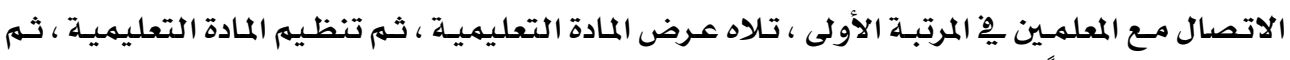

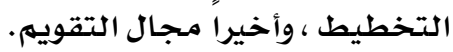

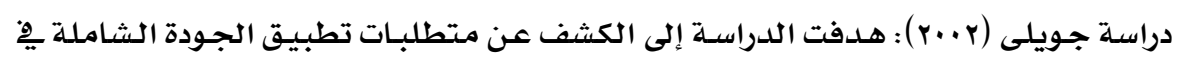

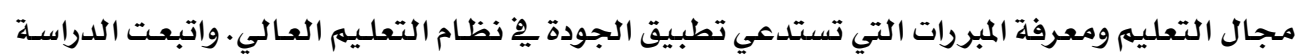

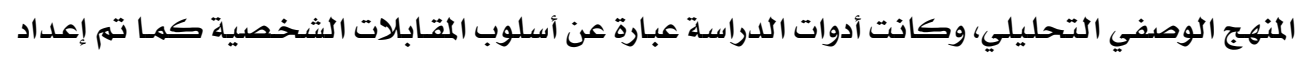

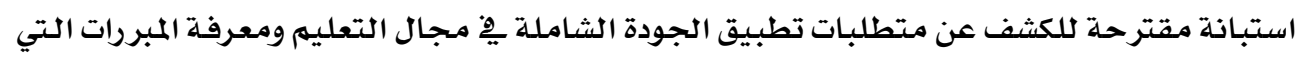

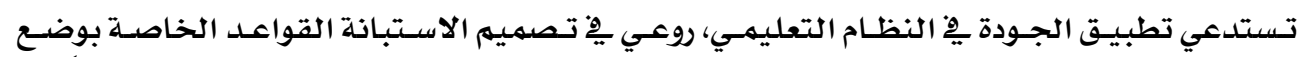

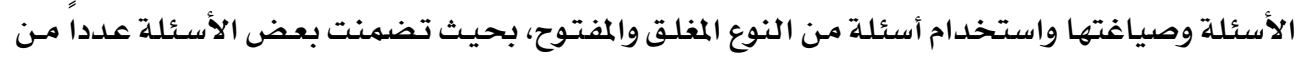

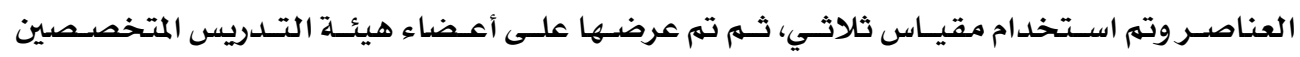

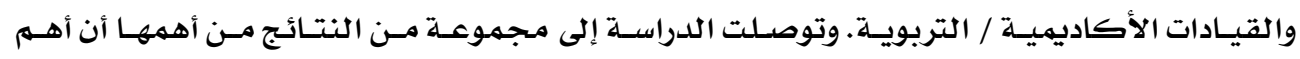

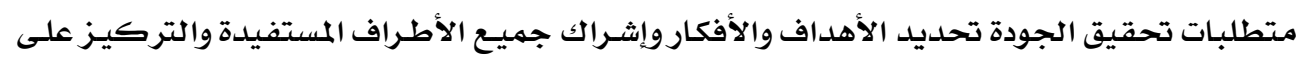

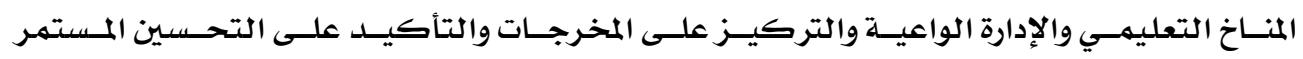
والتغذية الراجعة.

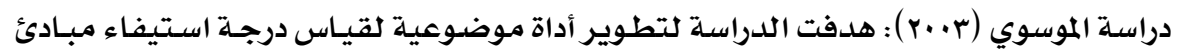

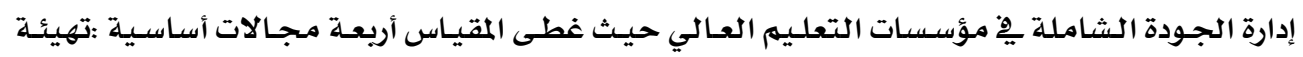

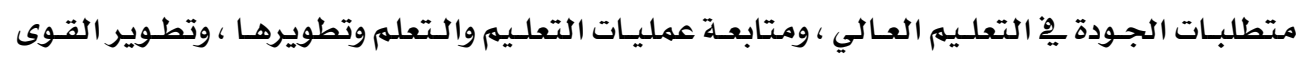

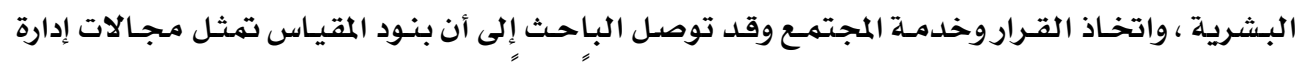

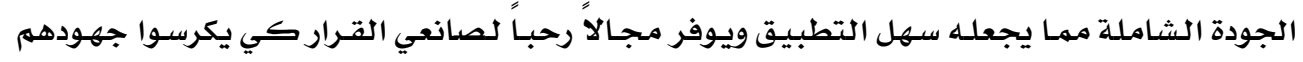

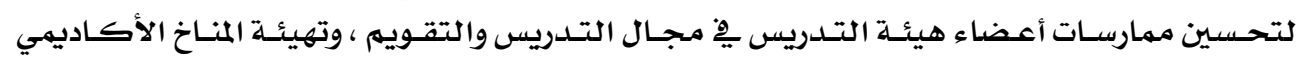

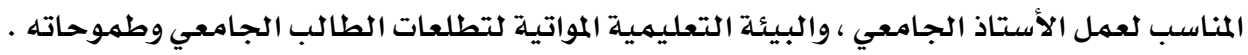

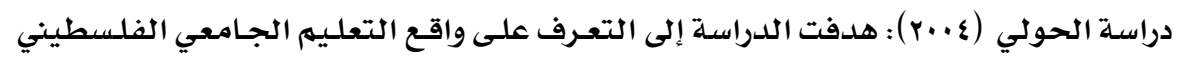

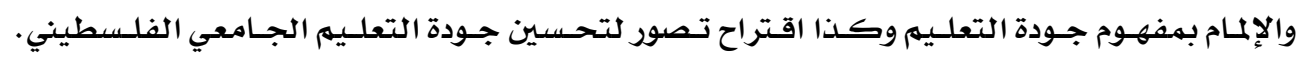

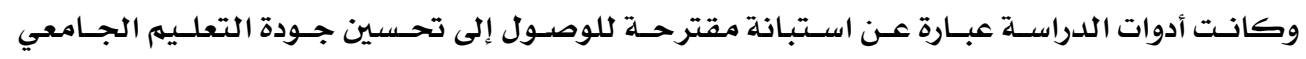

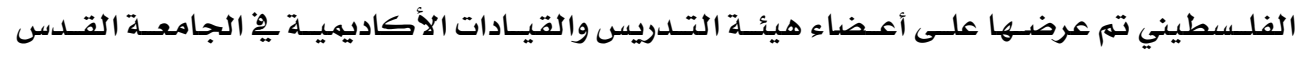

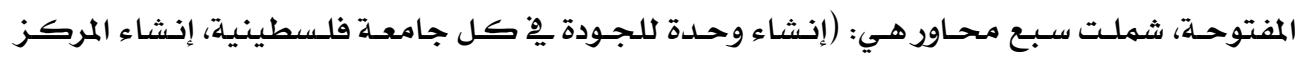

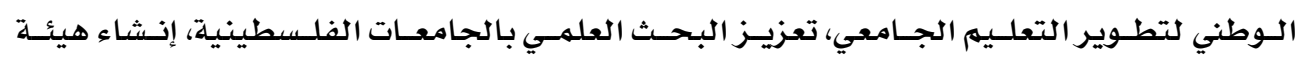

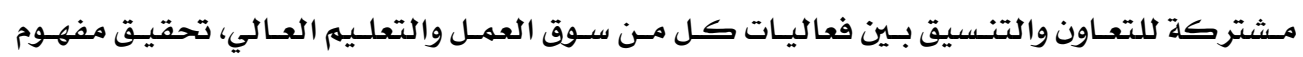

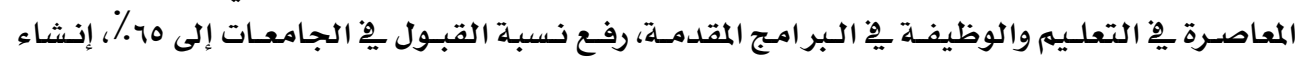

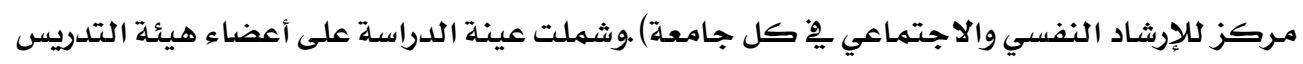

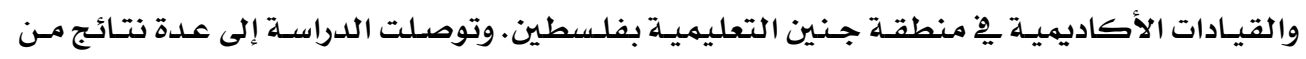
أهمها ما يلي: وادئي الادي 
تحديـد جوانب قصور التعليم الجـامعي الفلسطيني، منهـا (ارتفـاع تكاليف التعليم العـالي

وصعوبة السفروالتنقل بسبب معوقات الاحتلال اليهودي).

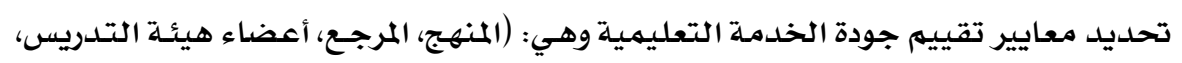

$$
\text { أسلوب التقييه، النظام الإداري، التسهيلات المادية). }
$$

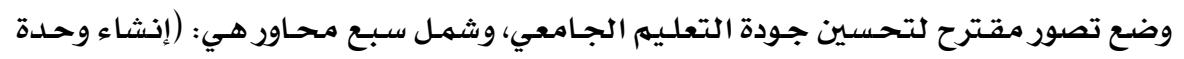

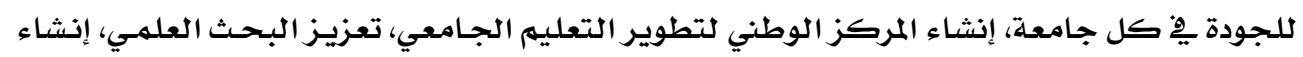

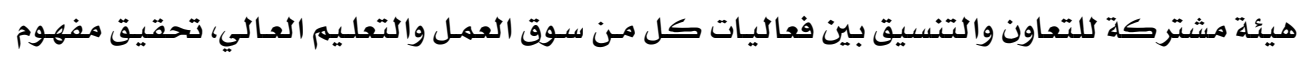

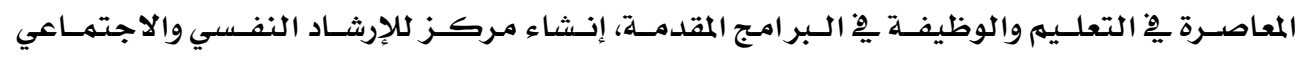

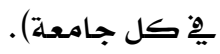

اقتراح دورة مهارات التدريس الجامعي (0؛ سـاعة تدريبيـة) تشمل سـت مواضيع هي: (مفهوم

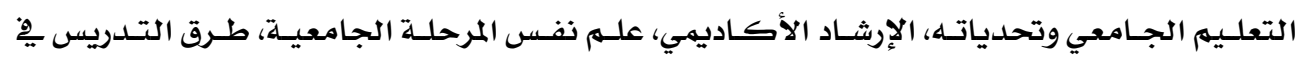

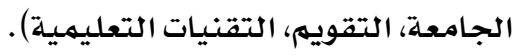

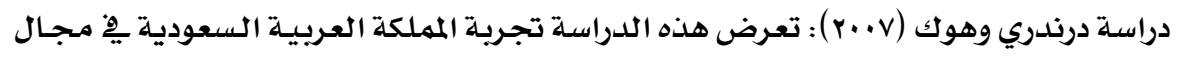

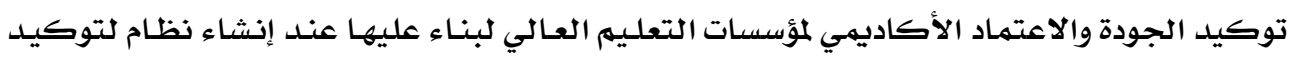

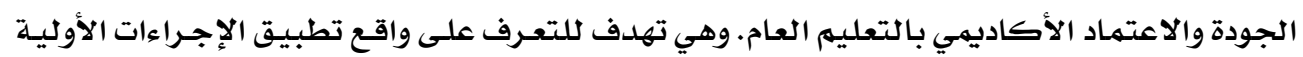

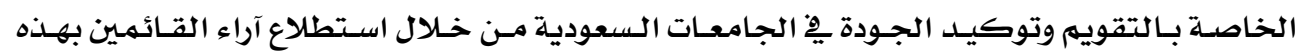

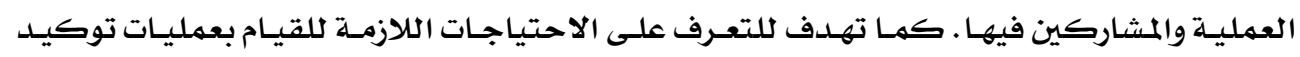

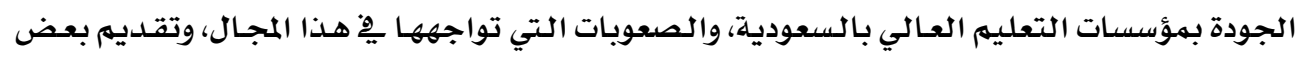

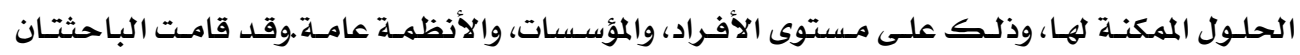

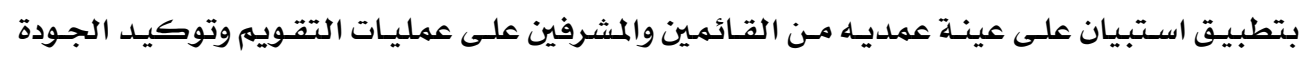

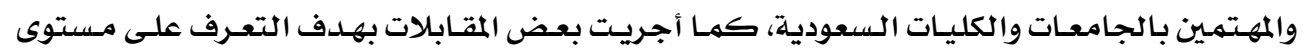

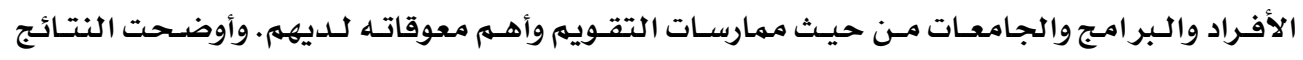

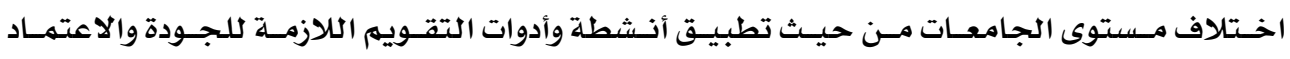

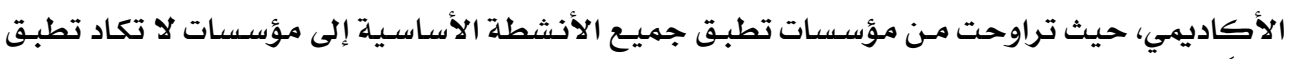

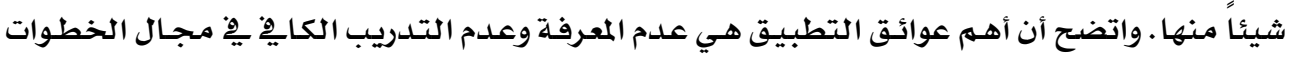

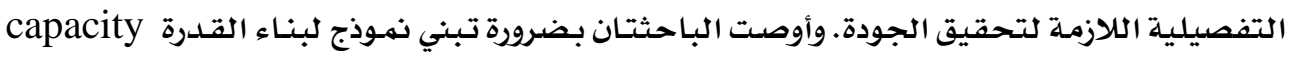

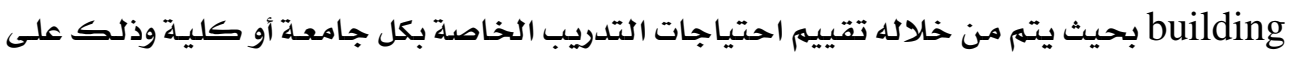

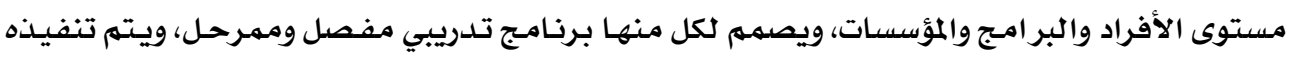

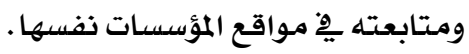
دراسة(Cornisky (2000) هـدفت الدراسـة إلى التعـرف على الكيفيـة التي يـتهم بها تطبيق

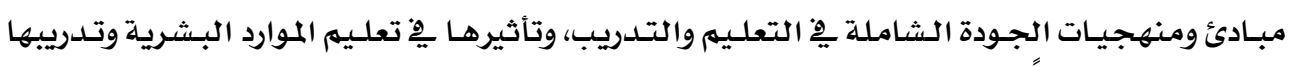

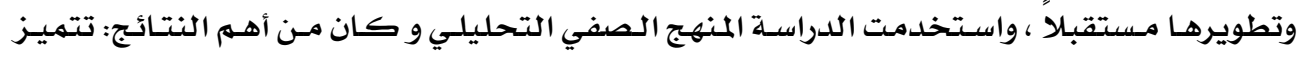


نهـاذج إدارة الجـودة الشاملـة بعنـاصـر مستركة بينها، والتي بـــورها تمثل أسس ومبـادئ إدارة الجـودة

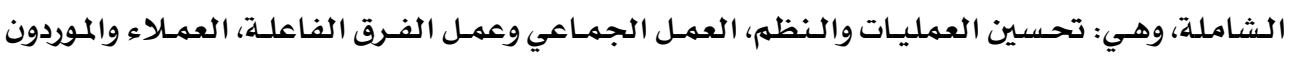

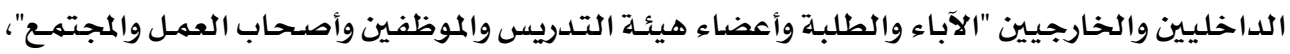

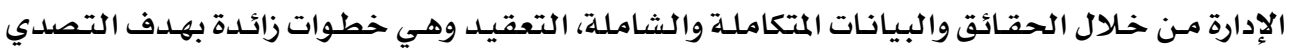

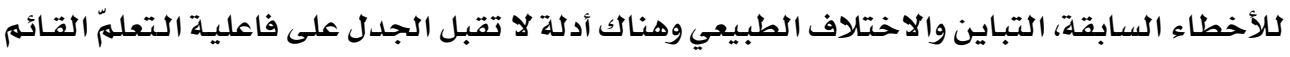

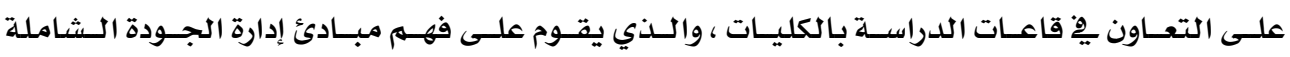

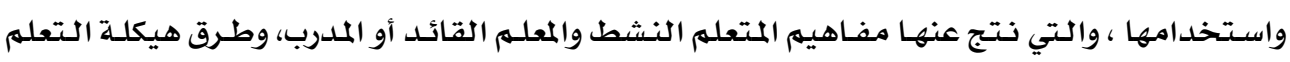

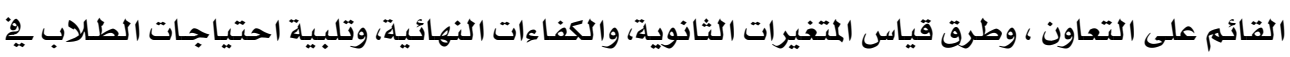
قاعات الدراسـة.

\section{تعقيب على الدراسات السابقة:}

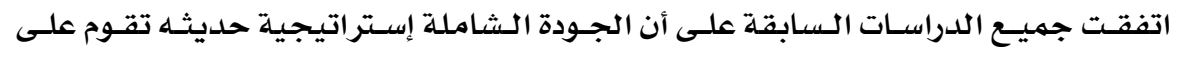

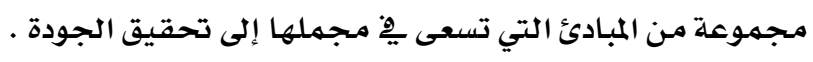

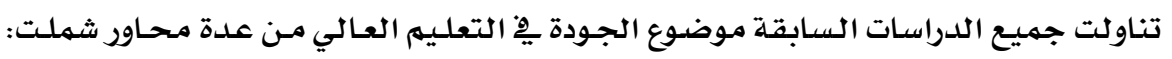

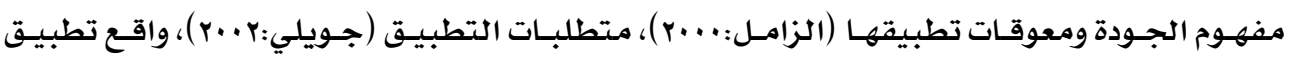

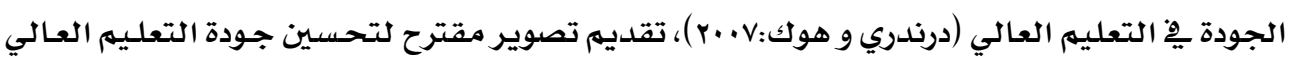

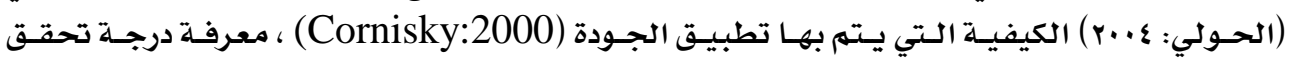

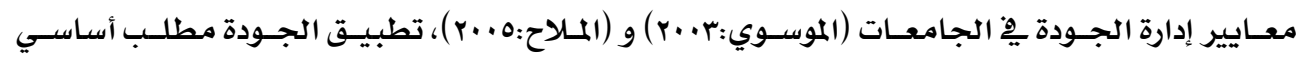

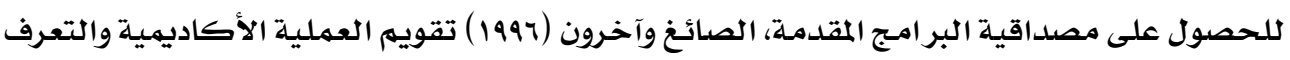

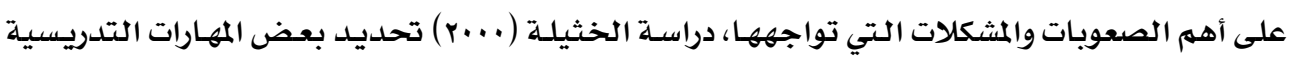

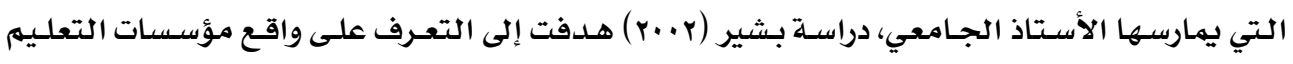

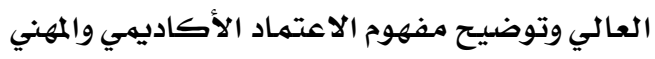

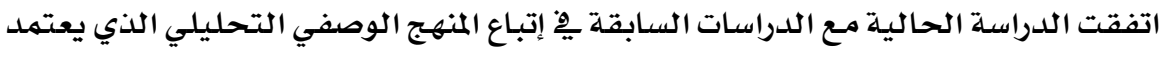

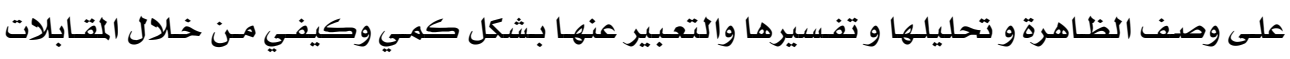
والاستبانات.

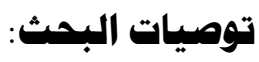

توصل الباحث إلى بعض التوصيات وهي كها يلي :

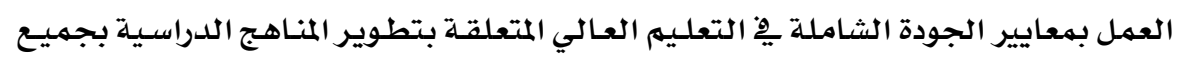
المستويات الجامعية.

ضرورة توفير المناخ التعليمي الملائم والتقيد به والحفاظ عليه . 
التأكيد على عضو هيئة التدريس أن يحترم شخصية الطلاب ، ففي قاعة المحاضـرات يكون

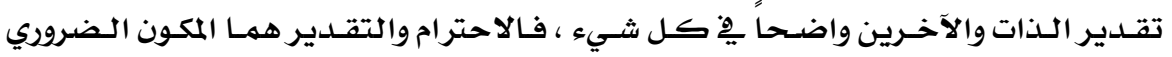

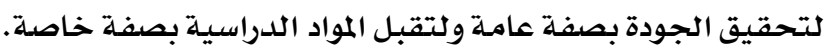
التأكيد على أعضاء هيئة التدريس بأن يستخدموا الحوار والمناقشة كوسيلة مهمهة لتنمية

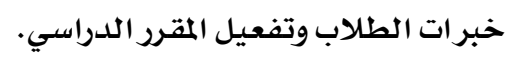

التأكيد على إستخدام عضو هيئسة التدريس لأسـاليب وأدوات مختلفـة لتقويم نواتج تعلسم

$$
\text { مقرره الدراسي وآدائه . }
$$

الحـرص على تبـادل الخبر ات بـين أعضاء هيئسة التـدريس السعوديين وغير السعودييين فيهـا

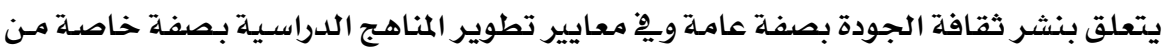

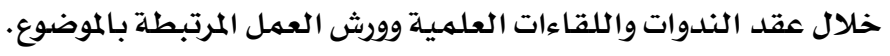
العمل بجميع العوامل التي تشجـع أعضاء هيئة التدريس على تقبل معـايير الجـودة الشـاملة • التأكيد على الاهتمام بالجانب الإنساني يِّ العمل. التأكيد على قيمـة العمل الجماعي داخل مؤسسات التعليم العالي . التأكيد على استخدام الحوافز الايجابية. الحرص على إزالة جميع المعوقات التي تحسد مـن تقبل أعضاء عيئسة التـدريس لمعايير الجـودة

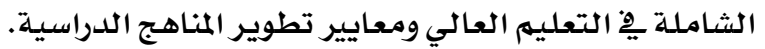

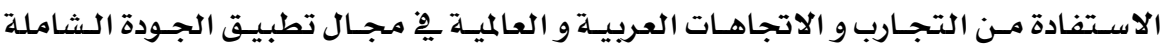

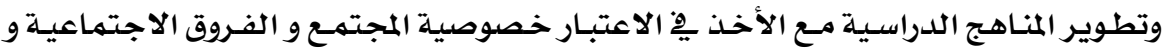
الحضاريية. تحديـد الاحتياجـات التدريبيـة الكلازمسة لكل كليـة على حسدة سـواء على مستوى الأفراد أو

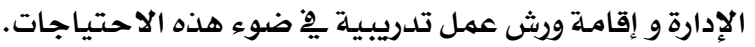

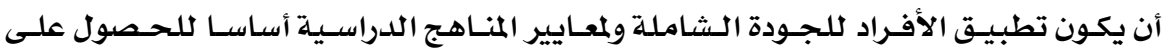
البدلات و الحوافزوالترقيات.

النتائج وتفنيرها سوف يتتم هٍِ هذا الجزء الإجابة عن تساؤلات البحث : التساؤل الأول: ما مدى تقبل أعضاء هيئة التدريس بجامعة الطائف لمعايير تطوير المناهج الدراسية يِّ ضوء الجودة الشاملة؟ ما ملدي تجيب الجداول التالية عن هذا التساؤل كمياً على النحو التالي:- 
جدول (1) يوضح النسبة المئوية لمدى تقبل أعضاء هيئة التدريس ( كلية التربية) لمعايير تطوير المناهج

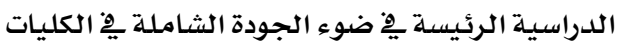

\begin{tabular}{|c|c|}
\hline المئوية العامة & معايير الجودة الشاملة في تطوير المناهج -المقررات الدراسية \\
\hline$\% 91$ & |التعليمية المكملة لها التمرات الدراسية ومعلومات عامة عنها ( مراجـة توصيف المقررات والمـواد \\
\hline$\%$ & |تحلديل الكفايات المعرفية والمهارية \\
\hline$\%$ \% & |تنظيم محتوى المنهج الدراسي ووسائل تطبيقه \\
\hline$\%$ & |لاستفادة من إمكانات وسائط العلم الحديث \\
\hline$\%$ \% & |إتباع آلية تحقق التكامل وتفادي التكرار | \\
\hline$\% \% \cdot$ & تصزيز أسلوب التعلم بالخبرة المباشرة \\
\hline$\%$ & |تعزيز أسلوب التعلم الذاتي \\
\hline$\% 70$ & تعزيز أسلوب التعلم الاككتوني \\
\hline$\% / 10$ & تتنمية خبرات جديلدة للى مطوري المناهج وأعضاء هيئة التدريس \\
\hline$\%$ \%o & تطوير أساليب التقويم أجراء تقويم دوري المخرجات التعليم \\
\hline$\% \vee V$ & توظيف مختلف مصادر التعلم داخل المؤسسة وخارجها \\
\hline
\end{tabular}

جدول (r) يوضح النسبة المئوية لمدى تقبل أعضاء هيئة التدريس ( كلية الآداب) لمعايير تطوير المناهج الدراسية

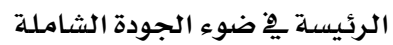

\begin{tabular}{|c|c|}
\hline النسبة المئوية & معايير الجودة الشاملة في تطوير المناهج -المقررات الدراسية \\
\hline$\%$. & 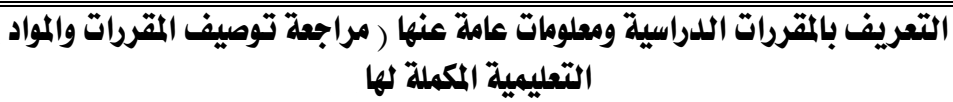 \\
\hline$\%$ \%० & تحديل الكفايات المعرفية والمهارية \\
\hline$\%$ \% & تنظيم محتوى المنهج الدراسي ووسائل تطبيقه \\
\hline$\%$ & الاستفادة من إمكانات وسائط العلم الحديث \\
\hline$\%$ \%r & إتباع آلية تحقق التكامل وتفادي التكرار \\
\hline$\%$ ro & تعزيز أسلوب التعلم بالخبرة المباشرة \\
\hline$\%$ & تعزيز أسلوب التعلم الذاتي \\
\hline$\%$ \% & تعزيز أسلوب التعلم الاككتوني \\
\hline$\%$ \%^A & تتنية خبرات جديلة لدى مطوري المناهج وأعضاء هيئة التدريس \\
\hline$\%$ \%r & تطوير أساليب التقويم أجراء تقويم دوري لمخرجات التعليم \\
\hline$\%$ & توظيف مختلف مصادر التعلم داخل المؤسسة وخارجها \\
\hline
\end{tabular}




\begin{tabular}{|c|c|}
\hline \multicolumn{2}{|c|}{ جدول (r) يوضح النسبة المئوية لمدى تقبل أعضاء هيئة التدريس ( كلية العلوم) لمعايير تطوير المناهج الدراسية } \\
\hline |النسبة المئوية العامة \% & معايير الجودة الشاملة في تطوير المناهج -المقررات الدراسية \\
\hline$\% 9 v$ & 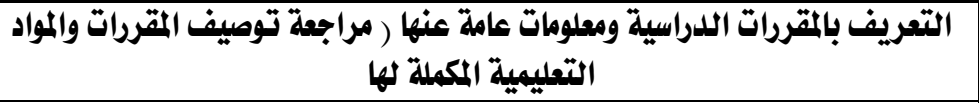 \\
\hline$\% 9 r$ & تحديل الكفايات المعرفية والمهارية \\
\hline$\%$ \% & تنظيم محتوى المنهج الدراسي ووسائل تطبيقه \\
\hline$\% \llbracket$ & الاستفادة من إمكانات وسائط العلم الحديث \\
\hline$\%$. & إتباع آلية تحقق التكامل وتفادي التكرار \\
\hline$\%$ & تعزيز أسلوب التعلم بالخبرة المباشرة \\
\hline$\%$ & تعزيز أسلوب التعلم الذاتي \\
\hline$\% 79$ & تعزيز أسلوب التعلم الاككتروني \\
\hline$\% .19$ & تنمية خبرات جديلدة للدى مطوري المناهج وأعضاء هيئة التدريس \\
\hline$\% \mathrm{VV}$ & تطوير أساليب التقويم أجراء تقويثم دوري لمخرجات التعليم \\
\hline$\%$ \% & توظيف مختلف مصادر التعلم داخل المؤسسة وخارجها \\
\hline
\end{tabular}

جدول (ع) يوضح النسبة المئوية لمدى تقبل أعضاء هيئة التدريس ( كلية الطب) لمعايير تطوير المناهج الدراسية

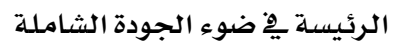

\begin{tabular}{|c|c|}
\hline || النسبة المئوية العامة ٪ | & معايير الجودة الشاملة في تطوير المناهج -المقررات الدراسية \\
\hline$\% 91$ & 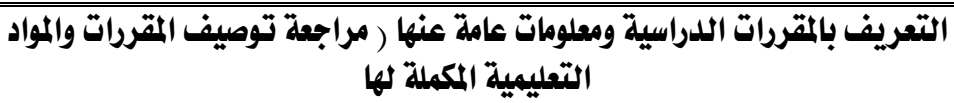 \\
\hline$\%$ & تحديل الكفايات المعرفية والمهارية \\
\hline$\% 91$ & تنظيه محتوى المنهج الدراسي ووسائل تطبيقه \\
\hline$\%$ Y Yo & الاستفادة من إمكانات وسائط العلم الحديث \\
\hline$\% 110$ & إتباع آلية تحقق التكامل وتفادي التكرار \\
\hline$\% 19$ & تعزيز أسلوب التعلم بالخبرة المباشرة \\
\hline$\%$ \% & تعزيز أسلوب التعلم الذاتي \\
\hline$\%$ \% & تعزيز أسلوب التعلم الاككتوذي \\
\hline$\% 9 r$ & تنمية خبرات جديلة للدى مطوري المناهج وأعضاء هيئة التدريس \\
\hline$\% 110$ & تطوير أساليب التقويم أجراء تقويم دوري المخرجات التعليم \\
\hline$\%$ & توظيف مختلف مصادر التعلم داخل المؤسسة وخارجها \\
\hline
\end{tabular}


جدول (0) يوضح النسبة المئوية لمدى تقبل أعضاء هيئة التدريس ( كلية الصيدلة) لمعايير تطوير المناهج

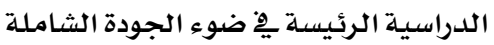

\begin{tabular}{|c|c|}
\hline |النسبة المئوية العامة \% | & معايير الجودة الشاملة في تطوير المناهج -المقررات اللدراسية \\
\hline$\% 9 r$ & التعريف بالمقررات الدراسية ومعلومات عامة عنها ( مراجعة توصيف المقررات والمواد التمليمية المهاد \\
\hline$\%$ & تحديد الكفايات المعرفية والمهارية \\
\hline$\%$ & تنظيم محتوى المنهج الدراسي ووسائل تطبيقه \\
\hline$\% / \wedge 1$ & الاستفادة من إمكانات وسائط العلم الحديث \\
\hline$\%$ \% & إتباع آلية تحقق التكامل وتفادي التكرار \\
\hline$\% \vee \wedge$ & تعزيز أسلوب التعلم بالخبرة المباشرة \\
\hline$\%$ Yo & تعزيز أسلوب التعلم الذاتي \\
\hline$\% \vee \vee q$ & تعزيز أسلوب التعلم الاكتروني \\
\hline$\% 9 r$ & تتمية خبرات جديلة للى مطوري المناهج وأعضاء هيئة التدريس \\
\hline$\% \wedge \Lambda$ & تطوير أساليب التقويم أجراء تقويم دوري المخرجات التعليم \\
\hline$\%$ \% & توظيف مختلف مصادر التعلم داخل المؤسسة وخارجها \\
\hline
\end{tabular}

جدول (T) يوضح النسبة المئوية لمدى تقبل أعضاء هيئة التدريس ( كلية الهندسة) لمعايير تطوير المناهج

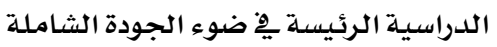

\begin{tabular}{|c|c|}
\hline ||النسبة المئوية العامة ٪|| & معايير الجودة الشاملة في تطوير المناهج -المقررات الدراسية \\
\hline$\% 91$ & التعريف بالمقررات الدراسية ومعلومات عامة عنها ( مراجعة توصيف المقررات والمواد \\
\hline$\% 90$ & تحليد الكفايات المعرفية والمهارية \\
\hline$\% / 19$ & تنظيم محتوى المنهج الدراسي ووسائل تطبيقه \\
\hline$\%$ & الاستفادة من إمكانات وسائط العلم الحديث \\
\hline$\%$ \% & إتباع آلية تُقق التكامل وتفادي التكرار \\
\hline$\% .79$ & تعزيز أسلوب التعلم بالخبرة المباشرة \\
\hline$\%$ \%. & تعزيز أسلوب التعلم الذاتي \\
\hline$\%$ & تعزيز أسلوب التعلم الاككتوذي \\
\hline$\% 94$ & تنمية خبرات جديلة لدى مطوري المناهج وأعضاء هيئة التدريس \\
\hline$\%$ \% & تطوير أساليب التقويم أجراء تقويم دوري المخرجات التعليم \\
\hline$\%$ & توظيف مختلف مصادر التعلم داخل المؤسسة وخارجها \\
\hline
\end{tabular}




\begin{tabular}{|c|c|}
\hline \multicolumn{2}{|c|}{ جدول (v) يوضح النسبة المئوية لمدى تقبل أعضاء هيئة التـريس ( كلية الحاسبـات ونظم المعلومات) لمعايير } \\
\hline | النسبة المئوية العامة ٪ | & معايير الجودة الشاملة في تطوير المناهج -المقررات الدراسية \\
\hline$\% 91$ & 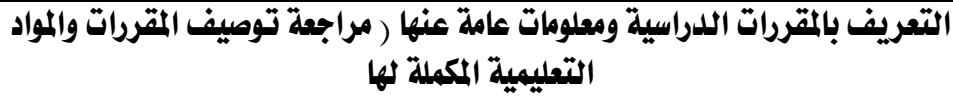 \\
\hline$\% 9 r$ & تحديلد الكفايات المعرفية والمهارية \\
\hline$\% \wedge \Lambda$ & تنظييم محتوى المنهج الدراسي ووسائل تطبيقه \\
\hline 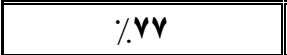 & الاستفادة من إمكانات وسائط العلم الحديث \\
\hline$\%$ \%乏 & إتباع آلية تحقق التكامل وتفادي التكرار \\
\hline$\% \wedge \wedge$ & تعزيز أسلوب التعلم بالخبرة المباشرة \\
\hline$\%$ \% & تعزيز أسلوب التعلم الذاتي \\
\hline$\%$ & تعزيز أسلوب التعلم الاكتروني \\
\hline$\%$ & تنمية خبرات جديلة للى مطوري المناهج وأعضاء هيئة التدريس \\
\hline$\% . \wedge 9$ & تطوير أساليب التقويم أجراء تقويم دوري لمخرجات التعليم \\
\hline$\%$ & توظيف مختلف مصادر التعلم داخل المؤسسة وخارجها \\
\hline
\end{tabular}

جدول (^) يوضح النسبة المئوية لمدى تقبل أعضاء هيئة التدريس ( كلية العلوم الادارية والمالية ) لمعايير تطوير

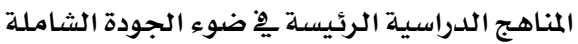

\begin{tabular}{|c|c|}
\hline 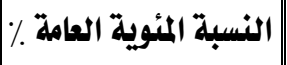 & معايير الجودة الشاملة في تطوير المناهج -المقررات الدراسية \\
\hline$\% \wedge \wedge$ & التعريف بالمقررات الدراسية ومعلومات عامة عنها ( مراجعة توصيف المقررات والمواد \\
\hline$\%$ \% Ar & تحديد الكفايات المعرفية والمهارية \\
\hline$\%$ \%. & تنظيبم محتوى المنهج الدراسي ووسائل تطبيقه \\
\hline$\%$ & الاستفادة من إمكاثات وسائط العلم الحديث \\
\hline$\% 170$ & إتباع آلية تُقق التكامل وتفادي التكرار \\
\hline$\%$ ro & تعزيز أسلوب التعلم بالخبرة المباشرة \\
\hline$\%$ & تعزيز أسلوب التعلم الذاتي \\
\hline$\%$ & تعزيز أسلوب التعلم الالكتروني \\
\hline$\%$. & تنمية خبرات جديلة للدى مطوري المناهج وأعضاء هيئة التدريس \\
\hline$\%$ & تطوير أساليب التقويم أجراء تقويم دوري لمخرجات التعليم \\
\hline$\%$ \% & توظيف مختلف مصادر التعلم داخل المؤسسة وخارجها \\
\hline
\end{tabular}


جدول (ه) يوضح النسبة المئوية لمدى تقبل أعضاء هيئة التدريس (كلية الشريعة والنظم) لمعايير تطوير المناهج

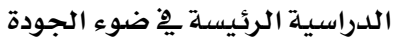

\begin{tabular}{|c|c|}
\hline |النسبة المئوية العامة \% | & معايير الجودة الشاملة في تطوير المناهج -المقررات الدراسية \\
\hline$\% 91$ & التعريف بالمقررات الدراسية ومعلومات عامة عنها ( مراجعة توصيف المقررات والمواد التمليمية المهاد \\
\hline$\%$ \%. & تحديد الكفايات المعرفية والمهارية \\
\hline$\%$ \% & تنظيم محتوى المنهج الدراسي ووسائل تطبيقه \\
\hline 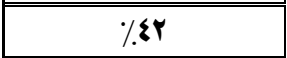 & الاستفادة من إمكانات وسائط العلم الحديث \\
\hline$\%$ & إتباع آلية تحقق التكامل وتفادي التكرار \\
\hline 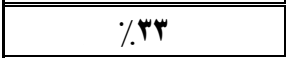 & تعزيز أسلوب التعلم بالخبرة المباشرة \\
\hline$\%$ \% & تعزيز أسلوب التعلم الذاتي \\
\hline$\%$ & تعزيز أسلوب التعلم الاكتروني \\
\hline$\%$ \% & تتمية خبرات جديلة للى مطوري المناهج وأعضاء هيئة التدريس \\
\hline$\%$ & تطوير أساليب التقويم أجراء تقويم دوري المخرجات التعليم \\
\hline$\overline{c \% r}$ & توظيف مختلف مصادر التعلم داخل المؤسسة وخارجها \\
\hline
\end{tabular}

جدول ( م ) يوضح النسبة المئوية لمدى تقبل أعضاء هيئة التدريس ( الاقتصاد المنزلي) لمعايير تطوير المناهج

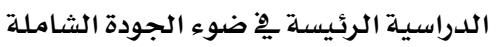

\begin{tabular}{|c|c|}
\hline || النسبة المئوية العامة ٪| & معايير الجودة الشاملة في تطوير المناهج -المقررات الدراسية \\
\hline$\% \wedge \uparrow$ & 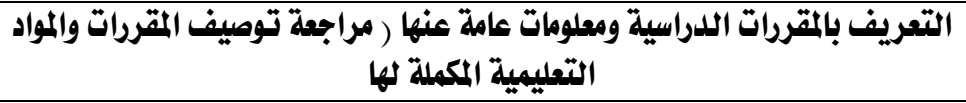 \\
\hline$\%$ \% & تحلديل الكفايات المعرفية والمهارية \\
\hline$\%$ & تنظيم محتوى المنهج الدراسي ووسائل تطبيقه \\
\hline$\%$ \% & الاستفادة من إمكانات وسائط العلم الحلديث \\
\hline$\%$ & إتباع آلية تخقق التكامل وتفادي التكرار \\
\hline 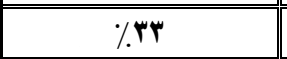 & تعزيز أسلوب التعلم بالخبرة المباشرة \\
\hline$\%$ & تعزيز أسلوب التعلم الذاتي \\
\hline$\%$ & تعزيز أسلوب التعلم الاكتروذي \\
\hline$\%$ \% & تنمية خبرات جديدة للى مطوري المناهج وأعضاء هيئة التدريس \\
\hline$\%$. & تطوير أساليب التقويم أجراء تقويم دوري المخرجات التعليم \\
\hline$\%(\mathrm{MI}$ & توظيف مختلف مصادر التعلم داخل المؤسسة وخارجها \\
\hline
\end{tabular}




\begin{tabular}{|c|c|}
\hline \multicolumn{2}{|c|}{ جدول (11) يوضح النسبة المئوية لمدى تقبل أعضاء هيئة التدريس ( العلوم الطبية التطبيقية) لمعايير تطوير } \\
\hline || النسبة المئوية العامة ٪\% & معايير الجودة الشاملة في تطوير المناهج -المقررات الدراسية \\
\hline$\% 97$ & 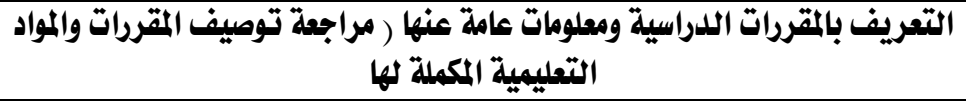 \\
\hline$\% 94$ & تحليل الكثايات المعرفية والمهارية \\
\hline$\%$ \% & تنظييم محتوى المنهج الدراسي ووسائل تطبيقه \\
\hline$\% \vee V$ & الاستفادة من إمكانات وسائط العلم الحديث \\
\hline$\% \vee \vee$ & إتباع آلية تحقق التكامل وتقادي التكرار \\
\hline$\%$ \% & تعزيز أسلوب التعلم بالخبرة المباشرة \\
\hline$\%$ \% & تعزيز أسلوب التصلم الذاتي \\
\hline$\% \wedge \Lambda$ & تعزيز أسلوب التعلم الاككتوني \\
\hline$\%$. 19 & تنمية خبرات جديلة لدى مطوري المناهج وأعضاء هيئة التدريس \\
\hline$\%$ \% & تطوير أساليب التقويم أجراء تقويم دوري لمخرجات التعليم \\
\hline$\% \wedge \wedge$ & توظيف مختلف مصادر التعلم داخل المؤسسة وخارجها \\
\hline
\end{tabular}

جدول (r) يوضـح النسبة المئوية لمدى تقبل أعضاء هيئة التدريس خدمة المجتمع والتعليم المستمر) لمعايير

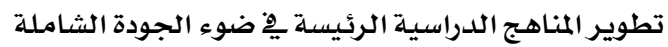

\begin{tabular}{|c|c|}
\hline 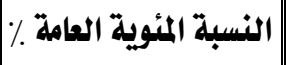 & معايير الجودة الشاملة في تطوير المناهج -المقررات الدراسية \\
\hline$\% \wedge \wedge$ & التعريف بالمقررات الدراسية ومعلومات عامة عنها ( مراجعة توصيف المقررات والمواد \\
\hline$\%$ & تحديد الكفايات المعرفية والمهارية \\
\hline$\% \vee 99$ & تنظيبم محتوى المنهج الدراسي ووسائل تطبيقه \\
\hline$\%$ & الاستفادة من إمكاثات وسائط العلم الحديث \\
\hline$\% 79$ & إتباع آلية تخقق التكامل وتفادي التكرار \\
\hline$\%$ & تعزيز أسلوب التعلم بالخبرة المباشرة \\
\hline$\%$ \% & تعزيز أسلوب التعلم الذاتي \\
\hline$\%$ & تعزيز أسلوب التعلم الاكتروذي \\
\hline$\%$. & تنمية خبرات جديلة للدى مطوري المناهج وأعضاء هيئة التدريس \\
\hline$\%$ & تطوير أساليب التقويم أجراء تقويم دوري لمخرجات التعليم \\
\hline$\%$. & توظيف مختلف مصادر التعلم داخل المؤسسة وخارجها \\
\hline
\end{tabular}




\section{تفسير تتائج التساؤل الأول كيفياً:}

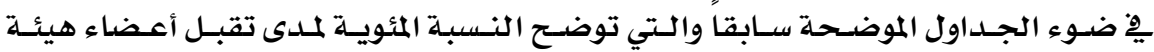

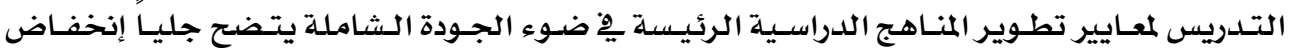

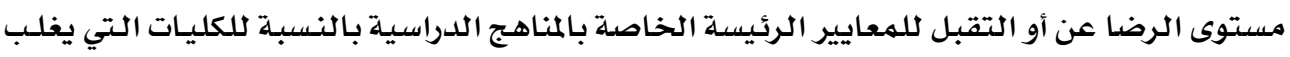

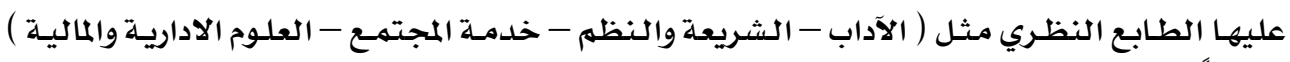

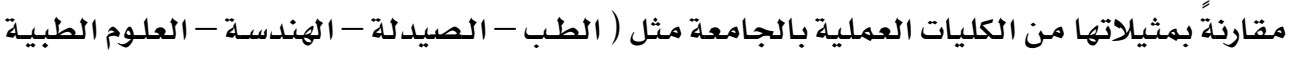

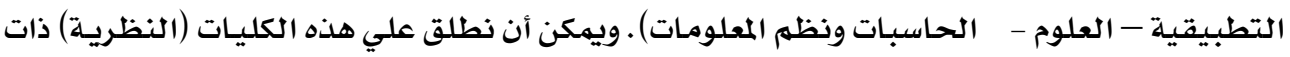

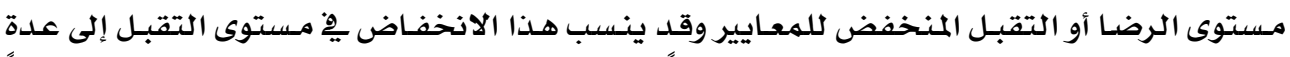

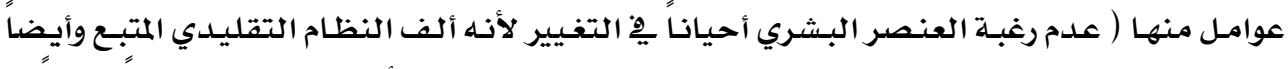

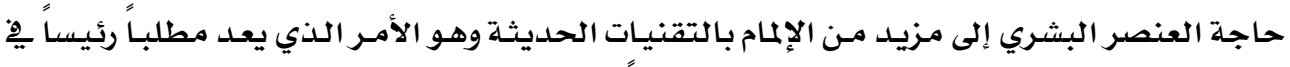

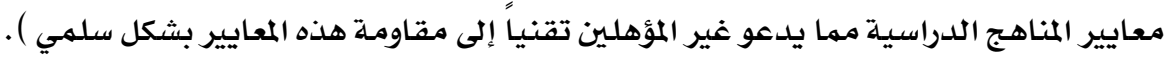

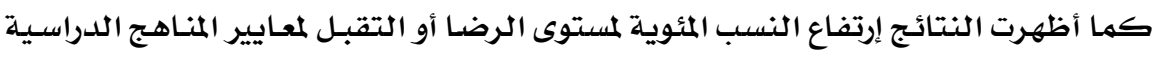

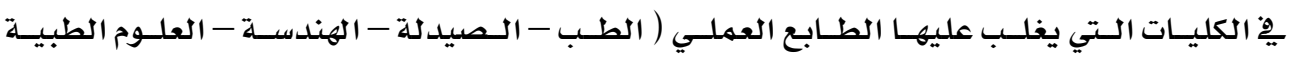

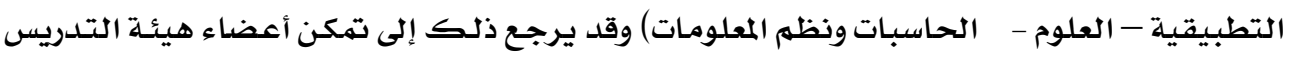

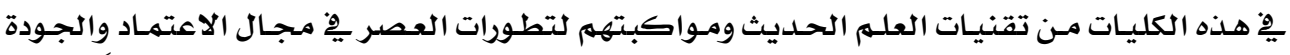

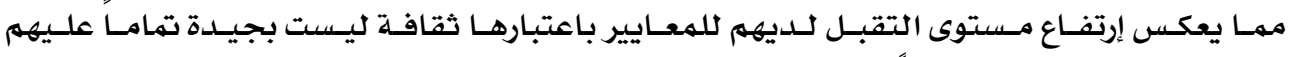

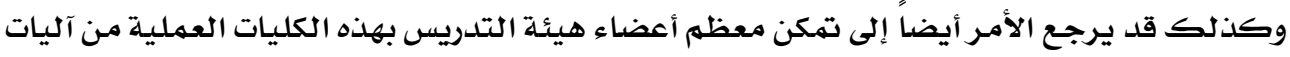

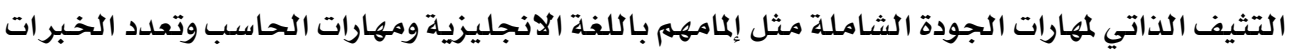

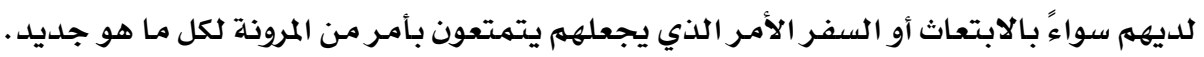

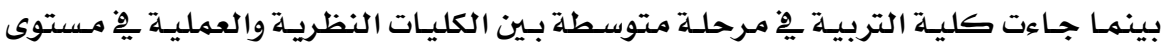

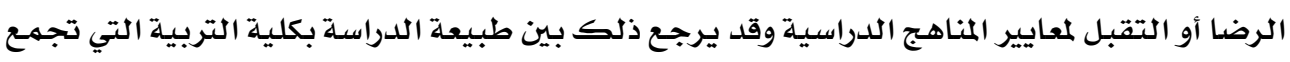

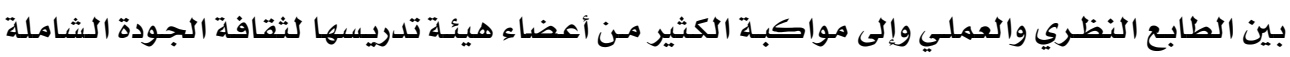
بحكم التخصص. التساؤل الثاذي:

ما هي العوامل التي تساعدهم على تقبل معايير تطوير المناهج الدراسية؟ وقد جاءت الإجابة يِّ ضوء مـا تكرر ذكره من قبل أفراد العينة على النحو التالي:

$$
\text { تقديم الحافز المادي والأدبي. }
$$

ريط تطبيق تطوير المناهج الدراسية بالترقيات.

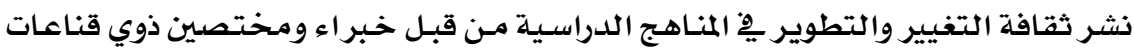

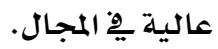


عرض خبر ات الدول المتقدمـة والتي نجحت ِِّ تطـوير مناهجها الدراسية وكـان ذلك سببا لتقدمها.

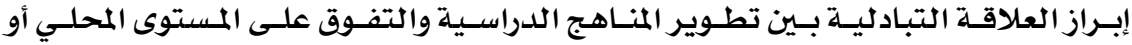

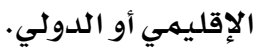

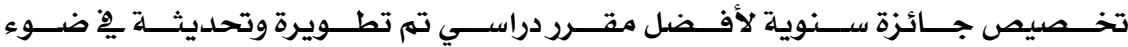

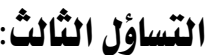

مـا المعوقات التي تقف حائلاً أمام تقبل معايير تطوير المناهج الدراسية؟ وقد جاءت الإجابة يِّ ضوء مـا تكرر ذكره من قبل أفراد العينة على النحو التالي:

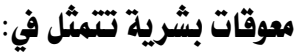

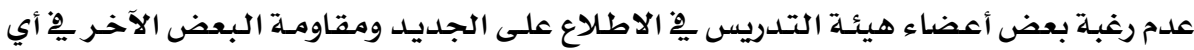
تغيير ورغبـة البعض الثالث يِّ الحفاظ على كل مـا هو مألوف لهم.

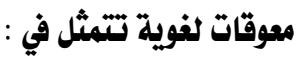

علدم إلمام بعض أعضاء هيئة التدريس باللغة الانجليزية مما يجعلهم غير قادرين على مواكبـة كل ما هو جديد من كتب أو مواقع إلكترونية باللغات الأخرى المرتبطة بمجال التطوير

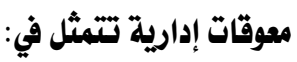

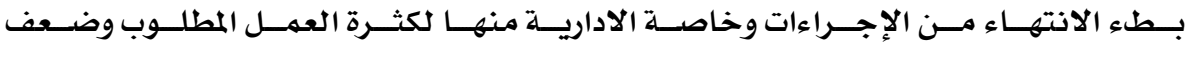
التقنيات أحيانا

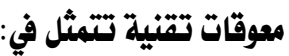

عدم توافر الحاسوب ومتطلباته بالشكل الكايِّ لدى بعض أعضاء هيئسة التدريس ويِّ القاعات الدراسية وأحياناً أخرى لعدم تمكن أعضاء هيئة التدريس من مهارات الحاسب الآلي. معوقات فنية تتمثل في:

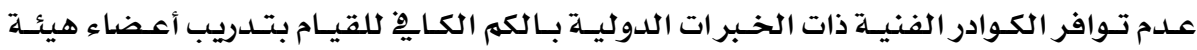
التدريس على معايير تطوير المناهج الدراسية والاعتمـاد والجودة الشاملة.

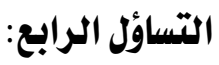

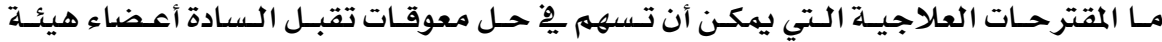
التدريس لمعايير تطوير المناهج؟ معات المعاجئ

وقد جاءت الإجابة يٌْ ضوء ما تكرر ذكره من قبل أفراد العينـة على النحو التالي:

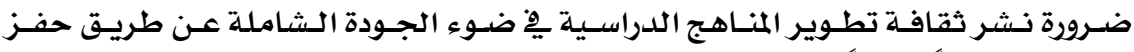
المشاركين أدبياً ومادياً. 


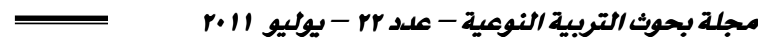

تزويد أعضاء هيئة التدريس بالأجهزة التقنيـة الحديثة لاستخدامها داخل القاعات.

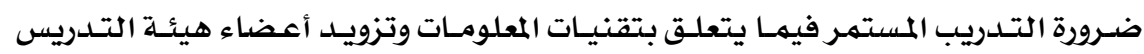
بالمواقع المتخصصدة يْ مجال تطوير المناهـج الدراسية والجودة.

المراجعة المستمـرة والدوريـة للهقرارات الدراسية يِ ضوء متطلبـات الاعتمـاد والجودة.

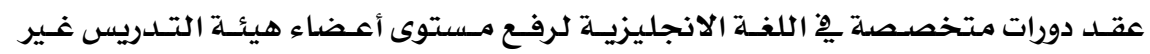
المتخخصصين. إتبـاع نظام المOT تدريب مجموعة مـن أعضاء هيئسة التـدريس للقيـام فيمـا بعـد بتـدريب مجمهوعة أخرى. التساؤز الخامس: مـا الأليـات الفعالـة لنشـر ثقافـة معـايير تطـوير المنـاهـج الدراسـيـة بـين أعضاء هيئـة تــريس

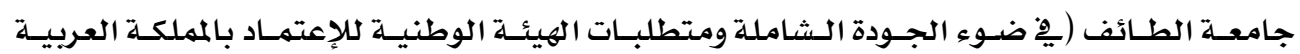
السعودية)

وقد جاءت الإجـابـة ِِّ ضوء مـا تكرر ذكره مـن قبل أفراد العينـة على النحو التالي:

عقد اللقاءات العلميـة المتكررة المرتبطة بهجال الجودة فِ كل كلية على حدة. دعوة خبر اء محليين ودوليين لإلقاء محاضـرات عامـة يْ مجال تطوير المناهـج الدراسية. تقديهم بعض الكتيبـات والمطويات عن معايير تطوير المناهـ الدراسية - الجودة - الاعتماد. تشجيع البـحوث المرتبطة بهـجال تطوير المناهـج الدراسية والجودة والاعتمـاد. تزويد المكتبـات الجامعية بقاعدة بيانات ورقيـة وإكترونيـة حلديثة يِ مجـال تطوير المنـاهـج

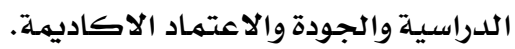
عقد ورث عمل لأعضاء هيئة التدريس بالكليات المختلفة يخ تطبيق معايير تطوير المنـاهـج

$$
\text { الدراسيـة. }
$$

تشجيـع الأقسـام على وضـع خطط بحثيـة لها على أن تتضهـن هـذه الخطط موضـوعات

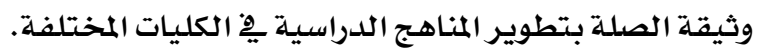

\section{المراجع العربية}

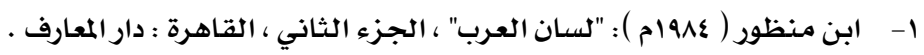

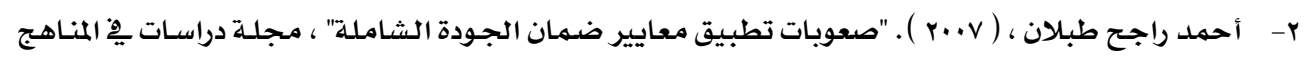
وطرق التدريس ، الجمعية المصرية للمناهج وطرق التدريس ، كلية التربية ، جامعة عين شمس ، القـاهرة

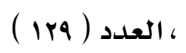

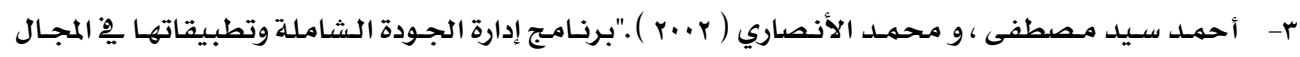
التربوي" ، الدوحة ، المركز العربي للتدريب التربوي لدول الخليج 


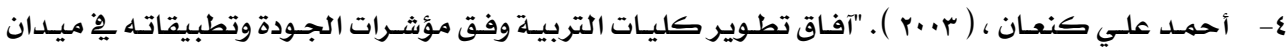
التعليم العالي" ، كلية التربية ، جامعة دمشق

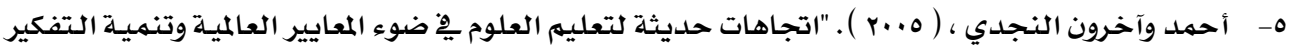
والنظرية البنـائية" ، طا، القاهرة : دار الفكر العربي .

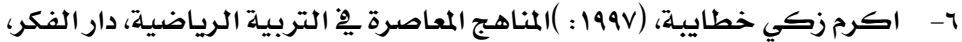

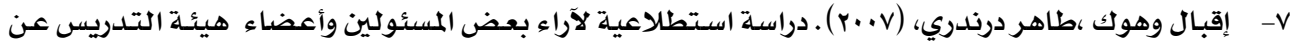

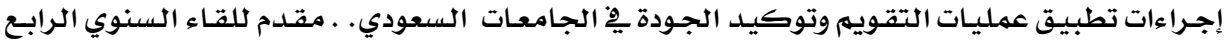
عشر للحهمعية السعودية للعلوم التربوية والنفسية (جستت) . القصسيم

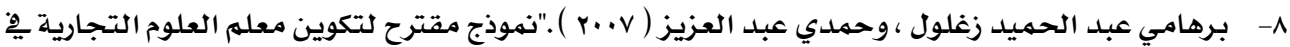
مصدر فِ ضوء معايير ضبط الجودة"، المؤتهر العلمـي التاسـع عشر (تطوير منـاهـج التعلـيم فِ ضـوء معايير الجودة )، 0 - جr يوليو ، دار الضبيافة ، جامعة عين شهس ، المحلد الثالث.

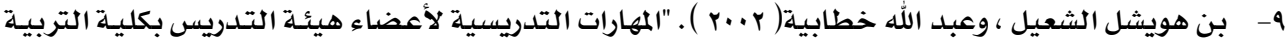
بجامعـة السـلطان قابوس وحساجتهم للتـدرب عليها مـن وجهة نظر طلبـة الدراسـات العليـا" ، مجلـة العلـوم الإنسـانية ، العدد (1/ ) ، الجززائر .

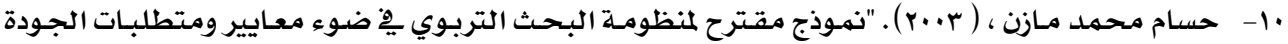

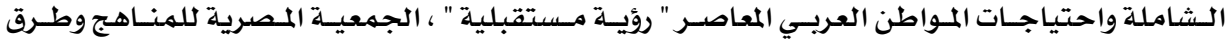

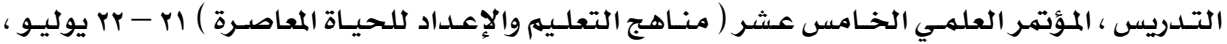
جامعة عين شمس ، المجلد الأول

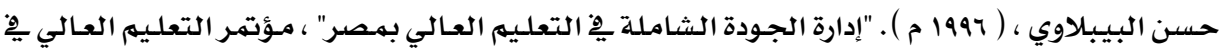
مصر وتحديات القرن الحادي والعشرين ، جامعة المنوفية ، ·r - اب مـايو ·

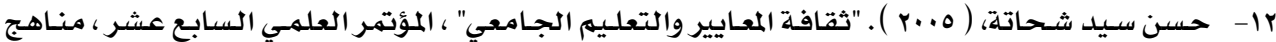
التعليم والمستويات المعيارية ، جr - Y r يوليو ، مجلد ( 1 ) ، جامعة عين شمس ، الجمعيـة المصرية للمنـاهـج وطرق التدربس

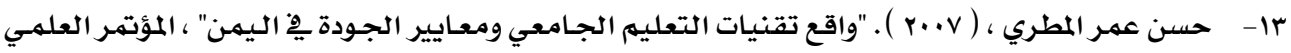

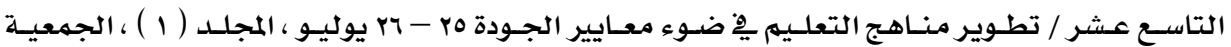
المصريـة للمناهـج وطرق التدريس

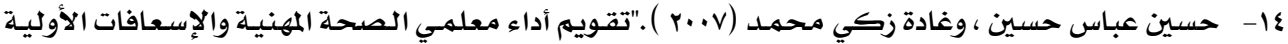

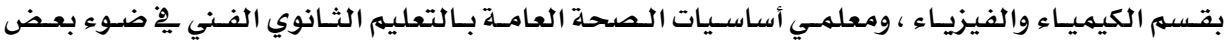

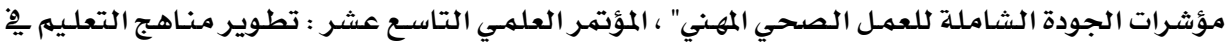
ضـوء معـايـر الجـودة ، 0ب - جr يوليـو ، جـامعـة عـين شمس ، الجمعيـة المصرية للهنـاهج وطـرق التـدريس ، •المجلد الثاني

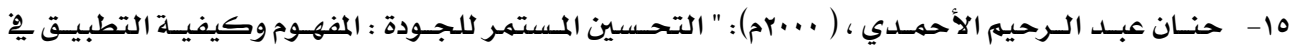
المنظمات الصحيةة" الإدارة العامـة ، المحلد الأربعون العدد الثادث . 


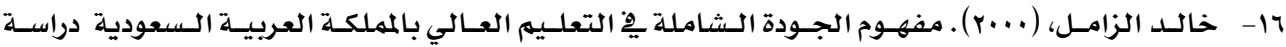
ماجستير (غير منشورة)، كلية التربية، جامعة الملك سعود .

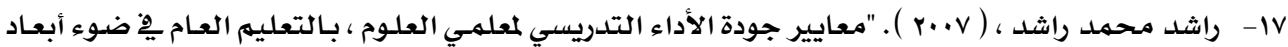

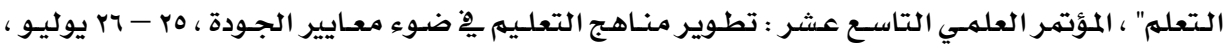
جامعة عين شمس ، الجمعية المصرية للهناهج وطرق التدريس ، المجلد (r) .

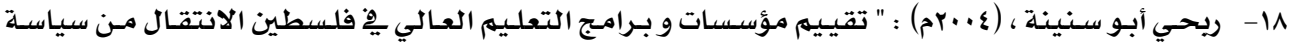

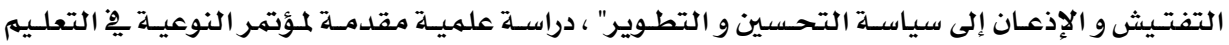

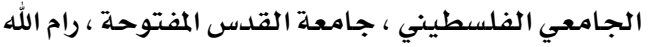

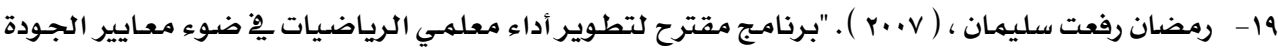

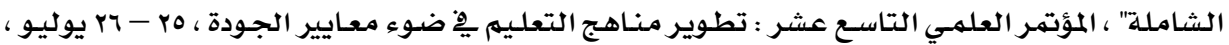
جامعة عين شمس ، الجمعية المصرية للمناهـج وطرق التدريس ، المجلد الرابع

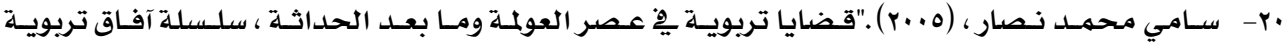
متجددة" ، القاهرة : الدار المصريية اللبنانية .

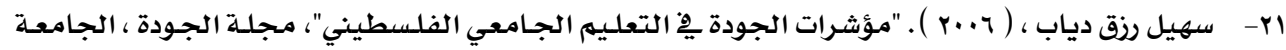

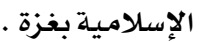

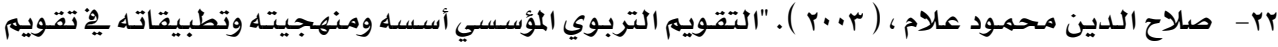
المدارس" ، القاهرة : دار الكتاب العربي الطبعة الاولى، عمان، ، ص OY - Y Y r. rr- عادل محمد عبد المنعمى ، (1991))، مجلة العلوم التربويـة ، كلية التربية ، جامعة الأزهر.

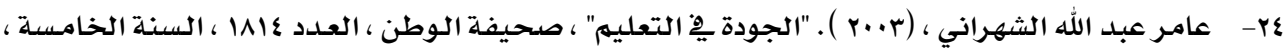
المملكة العربية السعوديية.

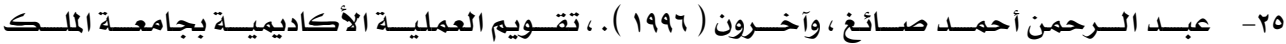

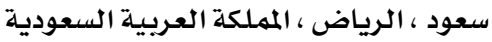

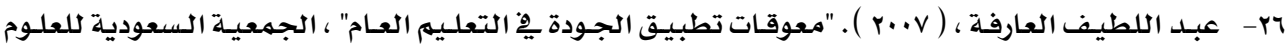
التربوية والنفسية ، كلية التربية ، جامعة الملك سعود ، المجلد الرابع

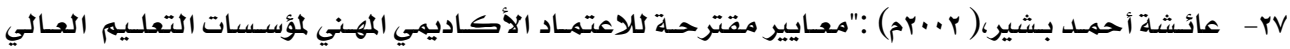
الخخاص يخ ضوء خبر ات بعض الدول"، رسالة ماجستير غير منشورة، كلية التربية، جامعة الزقازيق.

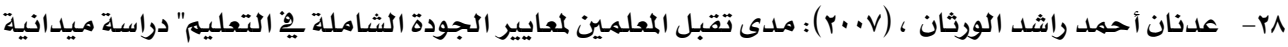
بمحافظة الأحسـاء، القـاء السنوي الرابـع عشر للجمعيـة السعودية للعلوم التربويـة والنفسية (جستنت) الجودة يِّإ التعليم العام

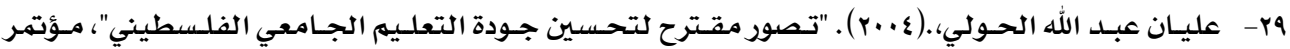

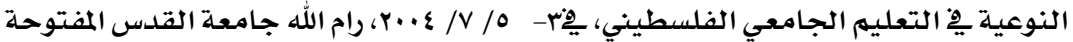

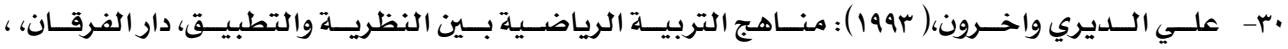
اريد، ص •rا 


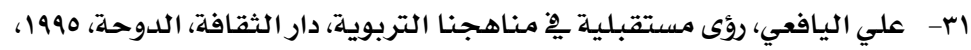

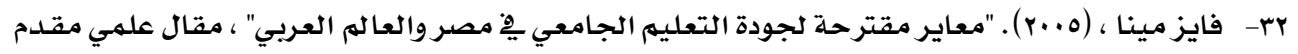

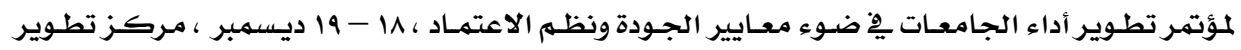

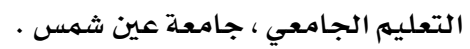

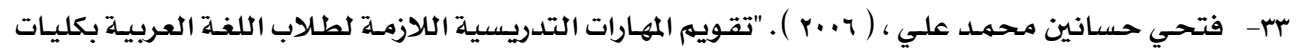

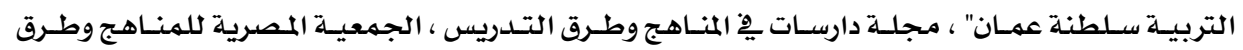
التدريس ، -11

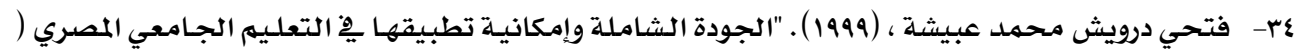

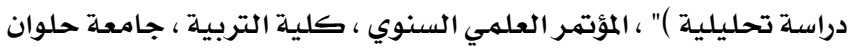

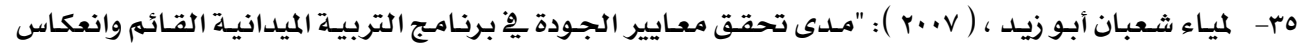

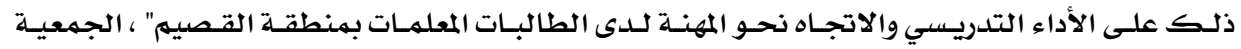

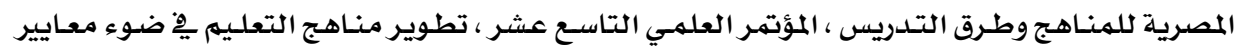

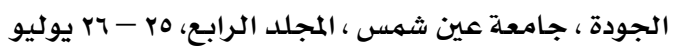

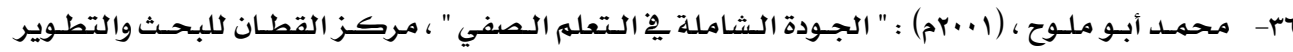

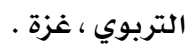

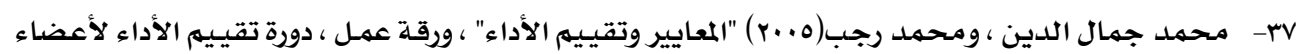

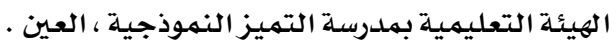

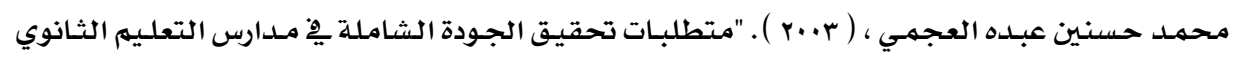

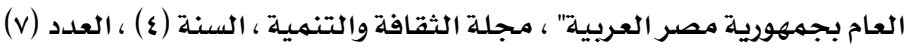

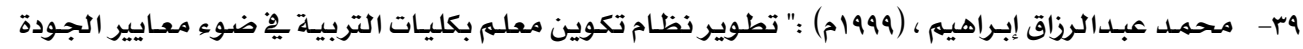

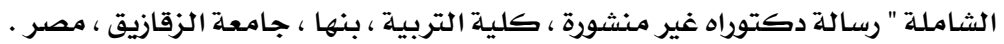

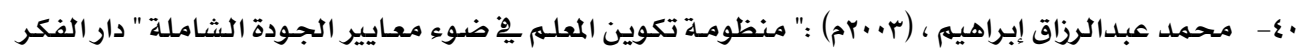

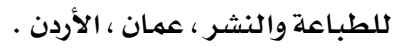

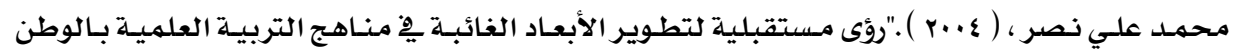

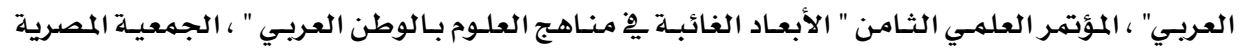

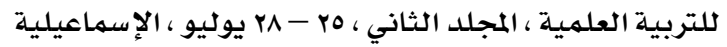

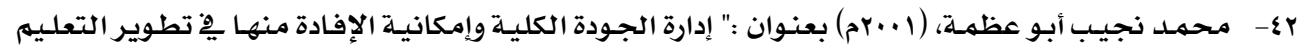

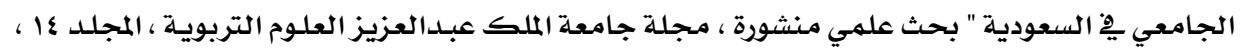
جامعة الملك عبدالعزيز ، جلده

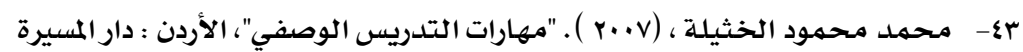

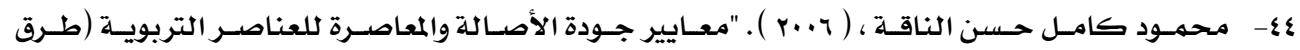

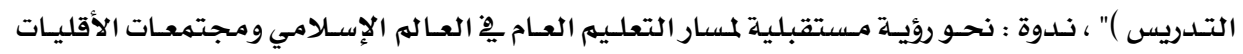

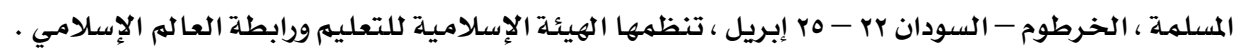




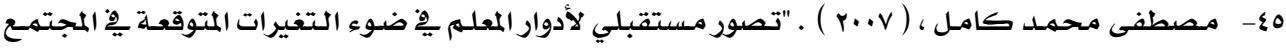

ومنظومـة التعليهم والمعايير القومية للتعليه" ، المؤتمر العلهي التاسـع عشر : تطوير مناهـج التعليهم ِِِ ضـوء

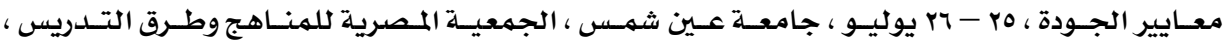
المجلد الثالث

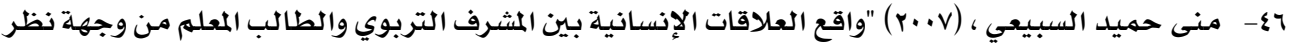

طـلاب التربيـة العمليـة بجامعـة أم القـرىى" ، مجلــة كليـة التربيـة ، جـامعـة عـين شهـس ، العـدد (اس ) الجزءء الرابع

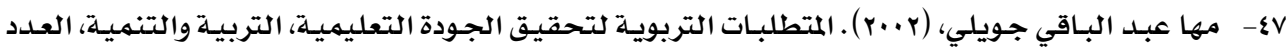
(r) )، القاهرة، جـامعة عين شمس.

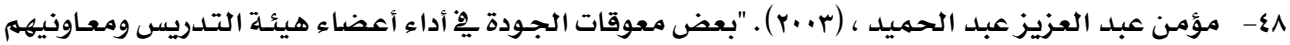

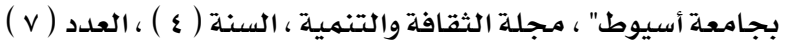

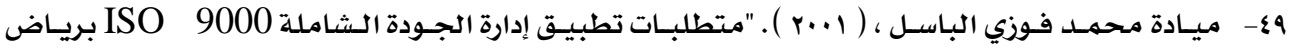

الأطفال ومدارس التعليهم العام بهصر ، دراسـة ميدانية" ، مجلة كلية التربية ، المنصورة ، العدد ( Vـ ) . .

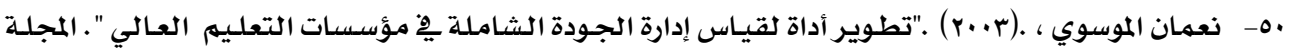
التربوية .عVIV، مجلد IV ، الكويت مجلس النشر العلمي

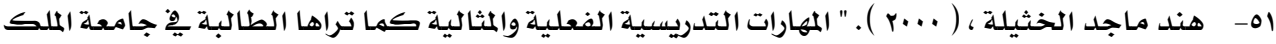

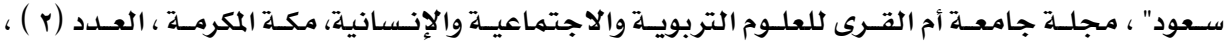
المجلد ( ا Ir )

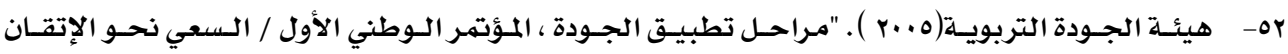
والتميز الواقع والطموح" ، المملكة العربية السعودية.

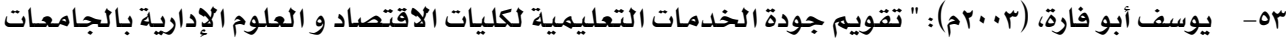
الفلسطينية "، دراسـة لمؤتتـر ضمان الجودة ، جامعة الزرقاء الأهليـة

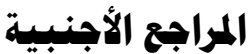

54- Abdullah S. Al-Tobi. (2006). "A Suggested Integrative Model for Pedagogical Courses in Science Teacher Edu." The Educational Journal, Issue No. 79, June

55-Bashshur, M , (1992 ) : Quality Education as a Catalyist for national unity.A paper presented at the CIES Conference, Annapolis Mb , March ,March

56- Brennan, J. (1998). Quality Assurance in Higher Education ALegislative Review and Needs Analysis of Developments in Central and Eastern Europe: EC/Phare/ETF copyright. 
57- Calpin-Davies, P., \& Donnelly, A. (2006). Quality assurance of NHS funded healthcare education. Nurs Manag (Harrow), 13(6), 28-34

58- Campbell, C., \& Rozsnyai, C. (2002). Quality Assurance and the Dvelopment of Course Programmes: Bucharest, UNESCO, CEPES Papers on Higher Education

59- Cheng, Y C ,(1997): School Educational Quality Conceptualization, Monitoring, and Enhancement, In sit ,P .K .Tam , P. Quality in Education : Insights from different perspectives. Hong Kong, Hong Kong , Educational Research Association.

60- Cizas, A. E. (1997). Quality assessment in smaller countries problems and Lithuanian approach. Higher Education Management. Global J. of Engng. Educ., 9(1), 43-48

61- Cooper, J. \& et, al. . (1999). "Classroom Teaching Skills", (6th ed.) Houghton Miffin, U.S.

62- Cornisky, R.(2000). Applications of Total Quality Management in Education and Training. A paper published in Education And Arab World "Challenges of Third Generations" Hand book. Emirates Center for Strategic Studies and Research. First edition. Abu dhabi.

63- David, B., \& Harold, T. (2000). Quality in Higher Education (Vol6): Routledge, part of the Taylor \& Francis Group.

64- Doherty, G , (Ed) ( 1994) : Developing Quality Systems in Education . London, Routledge

65- Elkhalich, F. Bell, R, Lederman, N. (1998). "The Nature of Science and Instructional Practice: Making the Unnatural Natural", Science Education, Vol. 82, No 4.

66- Gail, B. (1998). "Changes in your classroom from the past .To the present to the future", J.R.M.E, v.29, N.5.

67- Gibbs,G(1992): Improving the quality of student learning. Technical \&Education Services Ltd, U.K.

68- John, K. (2000) "Standards in the classroom, how teachers and syudents negotiate learning", Teachers college press, New york, copyright by teachers college, Colombia university. 
69- Leslay, C. (2007). "Early Childhood Intervention- All Countries Involved in the Project", www, European - agency.org/eci/word

70- Lewis, R. G. and Smith, D.H. (1997). "Why Quality Improved in Higher Education? “ International Journal, V. (1) N.(2)

71- Morgan, C., and Murgatroyd, S. (1994) :Total Quality Management in the Public Sector: International Perspective, 1st. Edition, Buckingham: Open University Press.

72- National Quality Assurance and Accreditation. (2004). The Quality Assurance and Accreditation Handbook: National Quality Assurance and Accreditation

73- Peters, R.S.(1969): Sociological comments on concepts of Quality In education In . C . E . Beeby (Ed) Qualitative Aspects of Educational Research, Vol.5, No.7

74- Poston Jr . William . (1997)"Comprehensive Study of Factors Impacting Perceived Quality in School Organizations : Findings from Research on Quality Assessment in Iowa school districts " Vol., 5 ,No.19

75- UK National Accreditation. (2004). Progrmme Specification Sport and Exercise.Unpublished manuscript

76- UNESCO International Institute For Educational planning : (2007): Planning :Paris Pp,149-167. 